\title{
EFEITO DO LODO DE ESGOTO (BIOSSÓLIDO) SOBRE A NÚTRICÃO, CICLAGEM DE NUTRIENTES E CRESCIMENTO DE SUB-BOSQUE, EM PLANTAÇÃO DE EUCALIPTO
}

\author{
MARCELINO CARNEIRO GUEDES \\ Engenheiro Florestal
}

Orientador: Prof. Dr. FÁBIO POGGIANI

Dissertação apresentada à Escola Superior de Agricultura "Luiz de Queiroz", Universidade de São Paulo, para a obtenção do título de Mestre em Ciências, Área de concentração: Ciências Florestais.

\footnotetext{
PIRACICABA

Estado de São Paulo - Brasil

Dezembro - 2000
} 


\title{
Dados Internacionais de catalogação na Publicação (CIP) DIVISÃo DE BIBUOTECA E DOCUMENTAÇÃO - campus "Luiz de Queiroz" /USP
}

\author{
Guedes, Marcelino carneiro \\ Efeito da aplicação de lodo de esgoto (biossólido) sobre a nutrição, cidagem de \\ nutrientes e crescimento de sub-bosque, em plantação de eucalipto / Marcelino \\ carneiro Guedes. - - Piracicaba, 2000. \\ $74 p$. \\ Oissertação'(mestrado) - - Escola SUperior de Agricultura Luiz de Queiroz, 2000. \\ Bibliografia.

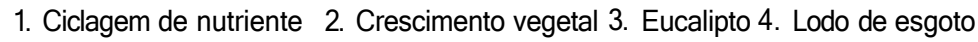 \\ 5. Nutrição vegetal 6. SUb-bosque I. Título
}

CoO 634.9734 
Dedico esta dissertação e todo o esforço realizado:

à memória de minha mãe, exemplo de dignidade, força e fé no trabalho. A gente pode até se acostumar com a falta que ela faz, mas esquecer jamais.

Ao meu filho Pedro Miguel, para que ele possa trilhar os caminhos da natureza e se deslumbrar com a chuva de flores do Ipê Branco. 


\section{AGRADECIMENTOS}

À Fundação de Amparo à Pesquisa do Estado de São Paulo (FAPESP), pela bolsa de mestrado concedida;

à Companhia de Saneamento Básico do Estado de São Paulo (SABESP), pelo financiamento do projeto de pesquisa coordenado pelo prof. Fábio Poggiani: "Estudo de Parâmetros de Aplicação do lodo da Estação de Tratamento de Esgoto (ETE) de Barueri no plantio de Eucaliptos" através do contrato 052/97-8 firmado com o IPEF;

ao Departamento de Ciências Florestais, ESALQ/USP, pela oportunidade de realizar o mestrado;

às inúmeras pessoas que de alguma maneira colaboraram com o desenvolvimento do trabalho, especialmente:

ao professor Fábio Poggiani, pela orientação;

aos professores José Leonardo de M Gonçalves, Maria Emília Mattiazzo Prezzoto e ao pesquisador Ronaldo S. Berton, pelas críticas e sugestões apresentadas;

aos amigos e colegas de projeto, Luiz Carlos de Faria, Luciano Mendes Sousa Vaz e Cristiano Alberto de Andrade, pela constante e sinérgica interação.

Peço desculpas aos que não citei os nomes. Tenho certeza que os que ajudaram com o coração aberto e espírito de boa vontade, não se sentirão injustiçados. 


\section{SUMÁRIO}

Página

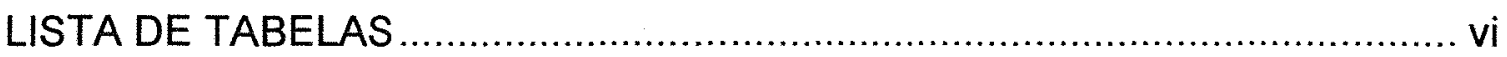

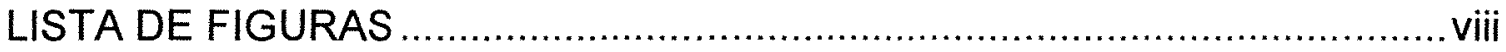

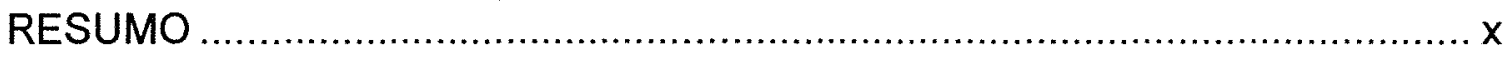

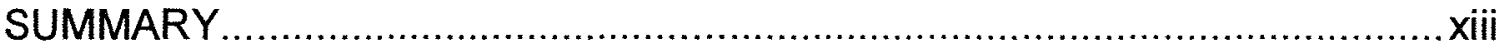

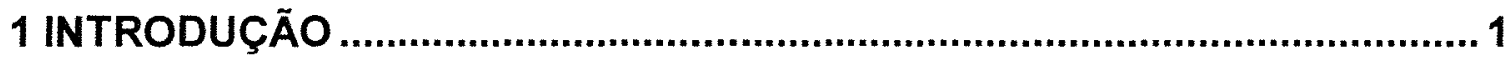

2 REVISÃO DE LITERATURA ............................................................. 5

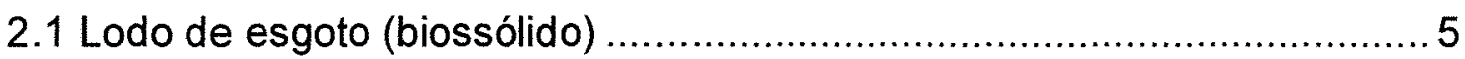

2.1.1 Tratamento do esgoto, produção e caracterização do lodo............5

2.1.2 Benefícios da utilização de biossólido ....................................... 8

2.1.3 Os possíveis problemas ........................................................... 10

2.1.4 Utilização em florestas ........................................................ 11

2.2 Nutrição mineral de eucalipto ............................................................. 14

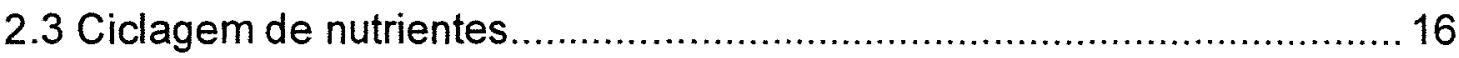

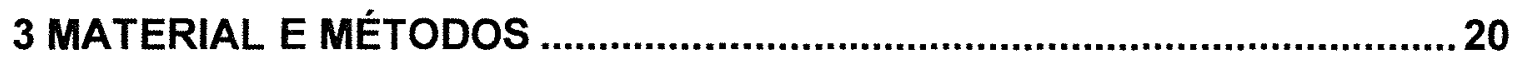

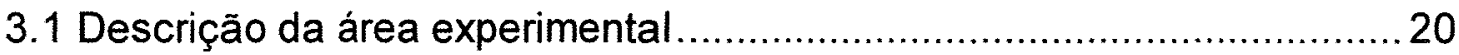

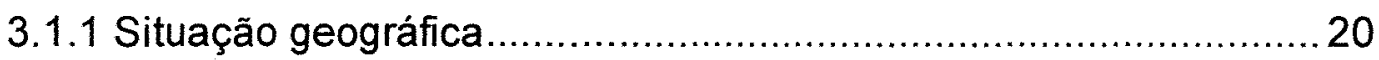

3.1.2 Plantio e tratos silviculturais no talhão experimental ...................20

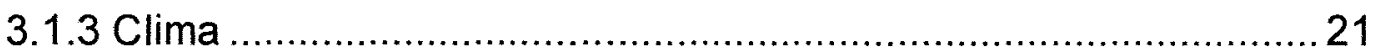

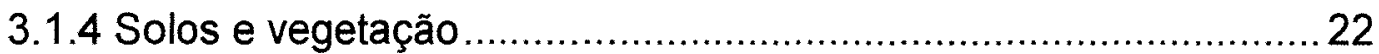

3.2 Caracterização e aplicação do biossólido ......................................... 23

3.3 Delineamento experimental e tratamentos ........................................... 25

3.4 Dados referentes ao crescimento do eucalipto .................................27

3.5 Coleta das amostras e metodologia de análise ...................................29

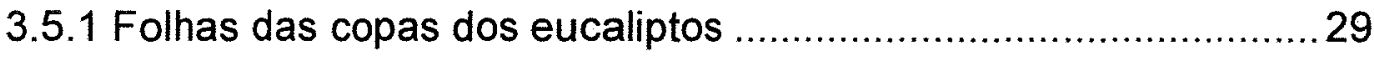

3.5.2 Amostras do folhedo produzido, acumulado e decomposto........... 29

3.5.3 Amostras da biomassa epígea do sub-bosque .......................... 31 
3.5.4 Luz incidente no sub-bosque ................................................ 31

3.6 Análise estatística dos dados ............................................................ 32

4 RESULTADOS E DISCUSSÃO ................................................................ 33

4.1 Avaliação do estado nutricional do eucalipto ....................................... 33

4.2 Ciclagem de nutrientes via folhedo ................................................. 48

4.2.1 Deposição de folhedo ................................................................. 48

4.2.2 Teores de nutrientes no folhedo e comparação com os da copa . 52

4.2.3 Deposição de nutrientes via folhedo ............................................ 56

4.2.4 Acúmulo de folhedo sobre o solo .............................................. 58

4.2.5 Decomposição do folhedo ...................................................... 60

4.3 Biomassa e nutrientes na vegetação de sub-bosque ............................. 61

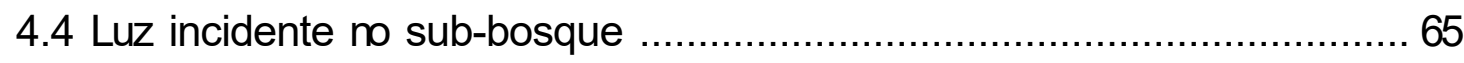

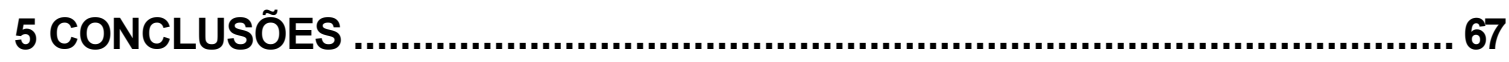

REFERÊNCIAS BIBLIOGRÁFICAS ....................................................... 68 


\section{LISTA DE TABELAS}

Página

Tabela 1. Caracterização química de biossólidos utilizados em alguns experimentos (Guedes e Poggiani, 1999).

Tabela 2. Caracterização química e física do solo da área experimental, em diversas profundidades (prof.). Segundo Vaz (2000).

Tabela 3. Caracterização do biossólido utilizado no experimento (elementos totais, base seca - $65^{\circ} \mathrm{c}$ ), produzido pela estação de tratamento de esgoto de Barueri.

Tabela 4. Resumo das anovas entre tratamentos (1), épocas de coleta (2) e das interações entre os tratamentos e as épocas (1x2); para os teores de nutrientes foliares (nut). Graus de liberdade: blocos (3), tratamentos (8), épocas de coleta (5), interação (40) e resíduo (159).

Tabela 5. Valores médios de seis épocas de coleta $(n=24)$, para a relação entre os teores de $\mathrm{Ca}$ e $\mathrm{Mg}$ nas folhas das plantas cultivadas nos diversos tratamentos (TT). Entre parênteses encontram-se os valores do erro padrão da média.

Tabela 6. Deposição média mensal $(n=4)$ de folhedo de eucalipto, durante o período de setembro de 1999 a agosto de 2000, nos tratamentos testados: testemunha (tt), adubação mineral (ad), $10 \mathrm{t} \mathrm{ha}^{-1}$ de biossólido mais K.e $P$ na base (10+KP), $20 \mathrm{t} \mathrm{ha}^{-1}$ de biossólido mais $\mathrm{K}(20+\mathrm{K})$ e $40 \mathrm{t}$ ha ${ }^{-1}$ de biossólido mais $\mathrm{K}(40+\mathrm{K})$

Tabela 7. Teores médios $(n=4)$ de macronutrientes em folhedo de eucalipto \pm erro padrão da média, depositado nos meses de novembro de 1999 e março de 2000, 16 e 20 meses após aplicação de biossólido

Tabela 8. Teores médios $(n=4)$ de micronutrientes e do elemento $\mathrm{Na}$ em folhedo de eucalipto \pm erro padrão da média, depositado nos meses de novembro de 1999 e março de 2000, 16 e 20 meses após aplicação de biossólido.

Tabela 9. Conteúdo de nutrientes em folhedo depositado pelo eucalipto nos meses de novembro de 1999 e março de 2000. 
Tabela 10. Valores médios $(n=12) \pm 0$ erro padrão da média, de peso seco do folhedo acumulado sobre o solo em cada época de coleta e média das quatro épocas $(n=48)$. As médias seguidas por letras iguais não diferem entre si, pelo teste de tukey a $5 \%$ de probabilidade

Tabela 11. Taxa instantânea de decomposição $(\mathrm{K})$, tempo médio de renovação $(1 / K)$ e tempo necessário para decomposição de $50 \%$ das folhas acumuladas na serapilheira (to,s), em função dos tratamentos testados

Tabela 12. Valores médios $(n=36) \pm$ desvio padrão, de biomassa seca do sub-bosque do eucalipto, para cada dose de biossólido complementado com potássio e tipo de material vegetal (TMV): não gramíneas (NG), gramíneas (G)

Tabela 13. Conteúdo total de nutrientes na vegetação, gramíneas mais não gramíneas, de sub-bosque de eucalipto, em função de doses de biossólido complementado com $\mathrm{K}$ 


\section{LISTA DE FIGURAS}

Página

Figura 1. Esquema da dinâmica de nutrientes em um ecossistema florestal (Poggiani et al., 2000; adaptado de Miller, 1984) ....

Figura 2. Médias mensais da temperatura máxima ( $T$ max) e temperatura mínima (T min) e valores de precipitação pluviométrica $(P)$ acumulados no mês, durante o período experimental.

Figura 3. Altura média das plantas de eucalipto, 10 meses após plantio e seis meses após aplicação do biossólido, nos nove tratamentos testados. Dados obtidos de Gonçalves et al. (1999 a)

Figura 4. Valores médios $(\mathrm{N}=4)$ do volume cilíndrico das árvores de eucalipto, medidas em julho-99, outubro-99 e janeiro-00. Nessas datas as plantas apresentavam, respectivamente, 14, 18 e 22 meses de idade. Dados obtidos de Gonçalves et al. (2000 b)

Figura 5. Valores médios $(M)$ e dos erros padrões das médias (EP) de teores de $\mathrm{N}$ foliar em eucalipto, em folhas coletadas durante seis épocas (de 2 a 16 meses após aplicação do biossólido), para cada tratamento testado $(\mathrm{N}=24)$..

Figura 6. Teores médios $(N=4)$ de $P$ nas folhas de eucalipto, em cada tratamento, para cada época de coleta diferente.

Figura 7. Teores médios $(\mathrm{N}=4)$ de $\mathrm{Ca}$ foliar em cada tratamento, dentro das diferentes épocas de coleta....

Figura 8. Teores médios $(\mathrm{N}=4)$ de $\mathrm{Mg}$ foliar em cada tratamento, dentro das diferentes épocas de coleta.

Figura 9. Valores médios (M) e dos erros padrões (EP) de teores de $S$ foliar em eucalipto. Médias de seis épocas de coleta $(N=24)$, para cada tratamento testado.

Figura 10. Teores médios de $M n$ foliar em cada tratamento $(N=4)$, dentro das épocas de coleta.

Figura 11. Correlação entre os teores de $\mathrm{Mn}$ e $\mathrm{Ca}$ foliares. Dados de todos os tratamentos e épocas de coleta $(\mathrm{N}=144)$. 
Figura 12. Teores médios ( $M$ ) e dos erros padrões (EP) das médias de $\mathrm{Zn}$ nas folhas de eucalipto, para cada tratamento testado, considerando todas as épocas de coleta $(\mathrm{N}=24)$

Figura 13. Média $(\mathbf{N}=4)$ da deposição anual de folhedo de eucalipto, durante o período de setembro de 1999 a agosto de 2000. Colunas sob letras iguais mostram que as médias não diferem entre si, pelo teste de Tukey a $5 \%$ de probabilidade.

Figura 14. Teores médios $(\mathbf{N}=4)$ de $\mathrm{N}$ em folhas das copas e no folhedo depositado, 16 meses (Nov/99) e 20 meses (Mar/00) após aplicação de biossólido

Figura 15. Teores médios $(\mathbf{N}=4)$ de Caem folhas das copas e no folhedo depositado, 16 meses (Nov/99) e 20 meses (Mar/00) após aplicação de biossólido

Figura 16. Teores médios $(\mathrm{N}=12,4$ repetições e 3 coletas) de macronutrientes em vegetação de sub-bosque de eucalipto, de acordo com o tipo de material vegetal (TMV), gramíneas $(G)$ ou não gramíneas (NG) e doses de biossólido complementado com K

Figura 17. Valores médios (M) e dos desvios padrões (DP) de luz difusa incidente sob as copas dos eucaliptos, medidos em junho de 2000, 27 meses após o plantio $(\mathrm{N}=64)$ 


\title{
EFEITO DO LODO DE ESGOTO (BIOSSÓLIDO) SOBRE A NUTRICÃO, CICLAGEM DE NUTRIENTES E CRESCIMENTO DE SUB-BOSQUE, EM PLANTAÇÃO DE EUCALIPTO
}

\author{
Autor: MARCELINO CARNEIRO GUEDES \\ Orientador: Prof. Dr. FÁBIO POGGIANI
}

\section{RESUMO}

A contaminação dos recursos hídricos por esgotos é um dos principais problemas enfrentados pela sociedade moderna, principalmente nos grandes centros urbanos. O tratamento dos esgotos gera um resíduo que, na maioria das vezes, é descartado em aterros sanitários, mas que poderia ser utilizado para aumentar a produtividade de culturas agrícolas ou florestais. $O$ objetivo geral desta pesquisa foi estudar o efeito da aplicação de biossólido, complementado ou não com fertilizantes minerais, sobre o balanço nutricional, a ciclagem de nutrientes e o sub-bosque de um povoamento jovem de Eucalyptus grandis Hill ex Maiden. O local de estudo situa-se na Estação Experimental de Itatinga, vinculada ao Departamento de Ciências Florestais, da ESALQ/USP. Para monitoramento nutricional, foram analisados os teores de macro e micronutrientes nas folhas dos eucaliptos, aos dois, quatro, seis, oito, doze e dezesseis meses após aplicação de biossólido. O estudo de ciclagem dos nutrientes foi iniciado dezessete meses após o plantio, por ocasião do fechamento das copas, e treze meses após aplicação do biossólido. Para análise do sub-bosque, foi quantificada a biomassa epígea e os teores de nutrientes, aos oito, dezesseis e vinte meses após aplicação. O experimento é delineado em blocos casualizados, com 4 repetições e 9 tratamentos: testemunha (tt), adubação mineral (ad), $5 \mathrm{t} \mathrm{ha}^{-1}$ de biossólido com $\mathrm{K}(5+\mathrm{K}), 10 \mathrm{t}$ 
ha ${ }^{-1}$ de biossólido com $\mathrm{K}(\mathbf{1 0}+\mathrm{K}), 10 \mathrm{tha} \mathrm{t}^{-1}$ de biossólido sem $\mathrm{K}(\mathbf{1 0}), 10 \mathrm{t} \mathrm{ha} \mathrm{a}^{-1}$ de biossólido com $K$ e $P$ na base (10+KP), $15 \mathrm{t} \mathrm{ha}^{-1}$ de biossólido com $\mathrm{K}(\mathbf{1 5}+\mathrm{K})$, 20 tha ${ }^{-1}$ de biossólido com $K(20+K)$ e 40 t ha $^{-1}$ de biossólido com K $(40+K)$. $O$ biossólido alterou, significativamente, o estado nutricional dos eucaliptos, exceto para o nutriente $\mathrm{Fe}$ e para o $\mathrm{Na}$. As plantas que receberam a maior dose de biossólido (40 $\mathrm{tha}^{-1}$ ) apresentaram maiores teores de $\mathrm{N}, \mathrm{P}, \mathrm{Ca}$ e menores concentrações de $\mathrm{Mn}$ e $\mathrm{Mg}$. As plantas tratadas com a maior dose de biossólido, depositaram $136 \%$ mais folhedo do que as plantas testemunhas e $40 \%$ a mais do que as plantas que receberam adubação mineral convencional. O tratamento " $20+K$ ", que recebeu $20 \mathrm{t} \mathrm{ha}^{-1}$ de biossólido apresentou, em todas as coletas, quantidades médias superiores de gramíneas no sub-bosque, porém em apenas dois blocos, o que determinou elevada variação em torno da média e a não significância estatística. A aplicação de biossólido em um povoamento jovem de E. grandis melhorou o estado nutricional das plantas, contribuiu para maior reciclagem biogeoquímica dos nutrientes dentro do ecossistema e não afetou de maneira homogênea o crescimento do subbosque. 


\title{
EFFECT OF SEWAGE SLUDGE (BIOSOLIDS) ON NUTRITION, NUTRIENTS CYCLING AND UNDERSTORY GROWTH, IN EUCALYPTUS PLANTATION
}

\author{
Author: MARCELINO CARNEIRO GUEDES \\ Advicer: Prof. Dr. FÁBIO POGGIANI
}

\section{SUMMARY}

The contamination of water resources for wastewater is one of the main problems faced by the modern society, mainly in the great urban centers. The treatment of wastewater generates a residue, most of the time discarded in landfills, that could be used to increase the productivity of agricultural or forest plantations. The general aim of this research was to study the effect of the biosolids application, complemented or not with inorganic fertilizers, on the nutritional status, nutrients ciclyng and understory of a young plantation of Eucalyptus grandis Hill ex Maiden. The trial was astablished in the Experimental Station of Itatinga, linked to the Department of Forest Sciences, of ESALQ/USP. For nutritional monitoring, leaves of eucaliptus were collected too, two, four, six, eight, twelve and sixteen months after biossolids application for macro and micronutrients analysis. The study of nutrients ciclyng has been initiated seventeen months after the plantation, for occasion of the closing of the crowns, and thirteen months after biosolids application. Analysis of the understory was carried out by quantifying the aboveground biomass and nutrients concentrations, to the eight, sixteen and twenty months after application. The experiment is designed in randomized blocks, with 4 replicates and 9 treatments: control (tt), inorganic fertilize (ad), $5 \mathrm{t} \mathrm{ha}^{-1}$ of biosolids with $\mathrm{K}(\mathbf{5}+\mathrm{K})$, $10 \mathrm{t} \mathrm{ha}^{-1}$ of biosolids with $\mathrm{K}(\mathbf{1 0}+\mathrm{K}), 10 \mathrm{th} \mathrm{a}^{-1}$ of biosolids without $\mathrm{K}(\mathbf{1 0}), 10 \mathrm{t} \mathrm{ha}^{-1}$ of biosolids with $K$ and $P(10+K P), 15 t^{2} a^{-1}$ of biosolids with $K(15+K), 20 \mathrm{tha}^{-1}$ of biosolids with $\mathrm{K}(20+\mathrm{K})$ and $40 \mathrm{tha}^{-1}$ of biosolids with $\mathrm{K}(\mathbf{4 0}+\mathrm{K})$. The biosolids 
altered, significantly, the nutritional status of the eucalyptus, except for $\mathrm{Fe}$ and $\mathrm{Na}$. The plants that received the largest biosolids rate $\left(40 \mathrm{tha}^{-1}\right)$, showed tha highest $\mathrm{N}, \mathrm{P}, \mathrm{Ca}, \mathrm{S}$ concentrations and the smallest concentrations of $\mathrm{Mn}$ and $\mathrm{Mg}$. The plants treated with the larger biosolids rate, deposited $136 \%$ more litterfall than the control plants and $40 \%$ where the plants received inorganic fertilizer. The treatment " $20+\mathrm{K}^{\mathrm{N}}$, that it received $20 \mathrm{t} \mathrm{ha}^{-1}$ of biosolids, showed highest medium amount of gramíneas in the understory, however in just two blocks, what determined high variation around the mean and the not statistical significance. The biosolids application in a young plantation of $E$. grandis has improved the nutritional status of the plants and it has contributed to larger nutrients recycling in the ecosystem. The understory growth has not been homogenously affected. 


\section{INTRODUÇÃO}

O desenvolvimento da consciência ecológica da sociedade e o avanço da legislação voltada para a área ambiental, vem exigindo da comunidade e das empresas de todos os setores um destino final, ecologicamente mais adequado, para os resíduos gerados durante suas atividades. No entanto, ainda constatase que, sem uma justificativa econômica, aquilo que seria ambientalmente correto fica em segundo plano e muitas vezes não é realizado. A popularização atual das questões ambientais ainda está longe de atingir o ideal, assim como a idéia do "desenvolvimento e do lucro a qualquer preço", herdada das gerações passadas, é muito difícil de ser banida.

É lamentável a situação caótica e dramática vivida pelos grandes centros urbanos, onde a perda de qualidade de vida e o desequilíbrio ambiental, são mais reais e visiveis, principalmente nas questões relacionadas à água. $A$ contaminação de recursos hídricos por resíduos urbanos é um problema que se torna cada vez mais comum. Atualmente, o lançamento de esgoto direto sobre os cursos de água, é uma das principais fontes de contaminação ambiental. A necessidade do tratamento dos esgotos é clara e incontestável. Basta olhar para os rios poluídos e mal cheirosos, para desejar evitar que o esgoto seja lançado diretamente sobre eles. No entanto, o tratamento também gera um resíduo, o lodo de esgoto, que, dependendo do manejo ao qual é submetido, pode criar outros problemas. $O$ que fazer com esse lodo gerado nas estações de tratamento de esgoto (ETE's)? Para onde deve ser levado?

Atualmente, a maior parte do lodo gerado no Brasil é destinado a aterros sanitários, o que representa altos custos financeiros, sociais e ambientais. Além disso, a disponibilidade de área é uma séria restrição à construção de novos 
aterros, que deveriam receber apenas resíduos sem qualquer possibilidade de reciclagem.

As pesquisas com lodo de esgoto vêm sendo realizadas há bastante tempo. Na década de setenta intensificaram-se essas pesquisas, expandindo os conhecimentos científicos sobre o lodo e sobre o processo de tratamento. Nos primeiros anos dessa década, muitos aspectos do uso de biossólido em florestas, incluindo técnicas de aplicação, práticas de manejo e operação e medida dos impactos ambientais, foram investigados (Henry e Cole, 1997).

Uma das alternativas mais promissoras para que as estações de tratamento de esgoto possam dar uma disposição final adequada ao lodo gerado, é sua utilização como biossólido em área florestais, utilizando-o como fertilizante e condicionador de solos para melhorar o desenvolvimento de árvores.

Atualmente, o termo biossólido vem sendo utilizado como substituto de lodo de esgoto, para diferenciar este produto com potencial de uso benéfico em culturas agrícolas e florestais, após as transformações microbianas e devida higienização, das fezes que o originou.

A Companhia de Saneamento Básico do Estado de São Paulo (SABESP), responsável pelo tratamento da água servida na região metropolitana, está empenhada em dar um destino, ecologicamente mais adequado, para a enorme quantidade de lodo produzida diariamente em suas estações de tratamento. A empresa vem financiando pesquisa para testar a utilização do lodo como biossólido em áreas florestais.

Segundo Faria e Rodrigues (2000), o potencial de uso do biossólido da ETE de Barueri (SABESP) em áreas reflorestadas próximas à estação é muito grande. Os autores concluíram também que existe demanda para o uso de biossólido como fertilizante em plantios de Eucalyptus e Pinus no Estado de São Paulo.

Existia no estado de São Paulo, no final de 1999, uma área reflorestada de aproximadamente, 321.000 ha (Associação Brasileira de Celulose e Papel, 
1999). A produtividade florestal poderia ser aumentada com a utilização do biossólido, particularmente, nas áreas primitivamente ocupadas pelo cerrado, onde a silvicultura com espécies de rápido crescimento é amplamente praticada e os solos são, geralmente, mais arenosos e de baixa fertilidade natural.

No Brasil, ainda não existem pesquisas conclusivas sobre a aplicação de biossólido em áreas florestais. Este é um trabalho pioneiro nessas condições e a falta de referências de estudos semelhantes dificulta muito a discussão dos resultados, exigindo uma análise muito mais criteriosa das variáveis medidas e cautela na conclusões.

As pesquisas sobre o uso de biossólidos em florestas plantadas no Brasil precisam ser estimuladas e outros estudos, em diferentes condições, necessitam ser desenvolvidos. O destacado desempenho nacional na silvicultura de eucalipto, pode ser incrementado ainda mais com o uso de biossólido, contribuindo também para que a disposição final deste resíduo gerado nas estações de tratamento, cada vez mais se realize de forma ecologicamente adequada.

No entanto não se pode perder de vista o caráter ainda experimental da aplicação de biossólido em florestas. É necessário que haja, realmente, certeza de que a atividade não trará nenhum prejuízo ao ambiente e às pessoas que lidam com esse material e conhecer a resposta em produtividade das culturas florestais, antes de estimular seu uso extensivo. Além disso, é preciso ampliar a fonte de dados sobre o assunto, para aprimorar a legislação nacional pertinente, que foi formulada a partir das normas americanas e apresenta necessidades de adaptações para as diferentes características do território brasileiro.

O trabalho que originou a presente dissertação é parte de um programa mais amplo, multidisciplinar, resultado de um contrato de pesquisa entre a Companhia de Saneamento Básico do Estado de São Paulo (SABESP), o Instituto de Pesquisas e Estudos Florestais (IPEF) e a ESALQ/USP, que vêm estudando a utilização de lodo de esgoto como biossólido em florestas 
plantadas de eucalipto. Uma idéia geral do programa e a descrição dos subprojetos que o compõem, podem ser encontradas em Poggiani e Benedetti (1999). Se for comprovada viabilidade ecológica, silvicultural e econômica da utilização de biossólido em plantações de eucalipto; este resíduo, hoje problemático, no futuro poderá ser considerado um insumo, gerando assim um estímulo a mais para que os esgotos urbanos sejam tratados antes de provocar a poluição dos cursos de água.

O objetivo geral do trabalho desenvolvido foi verificar como o biossólido, complementado ou não com fertilizantes minerais, afeta o balanço nutricional, a ciclagem de nutrientes e o sub-bosque de um povoamento jovem de $E$. grandis. São objetivos específicos da dissertação:

1) avaliar se ocorre aumento dos teores de macro e micronutrientes em folhas de eucalipto, após aplicação de biossólido;

2) verificar se a aplicação de biossólido aumenta a produção de folhedo e deposição de nutrientes, bem como a decomposição do folhedo acumulado sobre o solo, alterando o processo de ciclagem biogeoquímica;

3) observar se o biossólido favorece o desenvolvimento do sub-bosque, principalmente, das espécies de gramíneas; 


\section{REVISÃO DE LITERATURA}

\subsection{Lodo de esgoto (biossólido)}

\subsubsection{Tratamento do esgoto, produção e caracterização do lodo}

O lodo de esgoto é o resultado do tratamento dos resíduos líquidos urbanos (domésticos, comerciais e industriais), encaminhados às estações de tratamento através das redes de esgoto. Durante o tratamento do esgoto, bactérias e outros microorganismos quebram as moléculas orgânicas que servem como fonte de energia para seu desenvolvimento, utilizando os nutrientes para crescerem e se reproduzirem. Quando eles morrem, vão constituir a massa orgânica de lodo. Existem vários sistemas de tratamento, que produzem lodos com características distintas. De acordo com Tsutya (2000), existem basicamente três tipos de lodos oriundos do tratamento de esgotos: primário (lodo bruto produzido nos decantadores primários, com coloração acinzentada, aspecto pegajoso e odor ofensivo), lodo ativado (produzido nos reatores biológicos, com aparência floculenta, coloração marron e odor pouco ofensivo se mantido em condições aeróbias) e lodo digerido (que passou por processo de estabilização biológica, sem odor ofensivo).

Segundo Assunção (1996), a ETE de Barueri produz os três tipos de lodo, que passam por um tratamento terciário gerando um lodo condicionado. Durante essa etapa do tratamento ocorre o condicionamento químico do lodo, que consta da adição controlada de $\mathrm{Ca}(\mathrm{OH})_{2}$ (Cal hidratada) e $\mathrm{FeCl}_{3}$ ao sistema, com dois objetivos principais: 1) provocar a coagulação dos colóides de origem orgânica e inorgânica dispersos no lodo e 2) provocar a precipitação 
química de metais sob a forma de hidróxidos, óxidos e sais, para sua remoção dos esgotos. $\mathrm{O}$ pH final atingido nesse processo é superior a 11 e as condições físico-químicas são muito propícias à precipitação de hidróxidos de $\mathrm{Fe}$, hidróxidos metálicos diversos, carbonatos de $\mathrm{Ca}$ e $\mathrm{Mg}$ e fosfatos hidratados de $\mathrm{Ca}$. Esse mesmo autor chama a atenção que a grande maioria dos trabalhos levantados sobre comportamento ambiental de lodos gerados em ETE's estuda lodos gerados na Europa e Estados Unidos, em estações que empregam apenas os tratamentos primário e secundário. Ele salienta que a ausência do condicionamento químico faz com que esses lodos sejam muito diferentes do resíduo fresco gerado em Barueri.

A partir do segundo semestre de 2000, a ETE de Barueri modificou o processo, passando a produzir lodo tratado com polímero e eliminando o condicionamento químico.

Santos e Tsutiya (1997) prevêem uma produção de $575 \mathrm{t} \mathrm{dia}^{-1}$ de lodo, no ano 2005, considerando somente as estações de tratamento da região metropolitana de São Paulo. Nos Estados Unidos, foi estimada uma produção de 6,9 milhões de toneladas durante o ano de 1998 (EPA, 1999).

Em geral, o lodo pode fornecer $N$ às plantas em quantidades satisfatórias, além de outros elementos como $\mathrm{P}, \mathrm{Ca}, \mathrm{Mg}, \mathrm{Zn}$ e $\mathrm{Cu}$. A seguir são apresentadas as composições químicas de biossólidos usados em experimentos (Tabela 1). 
Tabela 1. Caracterização química de biossólidos utilizados em alguns experimentos (Guedes e Poggiani, 1999).

\begin{tabular}{cccccccccccc}
\hline $\mathbf{N}$ & $\mathbf{P}$ & $\mathbf{K}$ & $\mathbf{C}$ org & $\mathbf{C a}$ & $\mathbf{M g}$ & $\mathbf{F e}$ & $\mathbf{C u}$ & $\mathbf{Z n}$ & $\mathbf{M n}$ & $\mathbf{p H}$ & $\mathbf{F T}$ \\
\hline 22 & 10 & 2 & 71 & 12 & 4 & 50000 & 905 & 1880 & 505 & 10,2 & $\mathrm{a}$ \\
40 & 20 & 4 & 250 & - & - & - & - & - & - & - & $\mathrm{b}$ \\
25 & 19 & 2 & - & 13 & 2 & - & 375 & 700 & 660 & - & $\mathrm{C}$ \\
13 & 26 & 3 & 160 & - & 6 & 54000 & 1039 & 4151 & 400 & - & $\mathrm{d}$ \\
- & - & - & 300 & - & - & - & 707 & 1880 & 820 & 6,0 & $\mathrm{e}$ \\
59 & 33 & - & - & - & - & - & 570 & 880 & 350 & - & $\mathrm{f}$ \\
19 & 8 & 1 & - & 36 & 3 & - & 217 & 525 & 157 & & $\mathrm{~g}$ \\
18 & 9 & - & $163^{*}$ & - & - & 70000 & 101 & 137 & 187 & 6,8 & $\mathrm{~h}$ \\
20 & 12 & 1 & - & 25 & 40 & 61000 & 335 & 151 & - & 6,1 & $\mathrm{i}$ \\
\hline
\end{tabular}

*matéria orgânica, -não apresentado

FT (Fonte): a- Silva (1995); b- Estados Unidos (1980); c- Giordano e Mays (1981); d- Bettiol e Carvalho (1982); e- Bettiol et al. (1982); f- Fiskell et al., (1990); g- Labrecque et al. (1995); hTsadilas et al. (1995); i- Wen et al. (1997)

Pode-se observar que a composição do lodo de esgoto é muito variada. Ela varia com as condições de vida da população geradora, proporção entre esgoto domiciliar e industrial e com o processo de tratamento adotado pela ETE. A qualidade do lodo está intimamente relacionada ao nível sócio-cultural da população e ele apresenta composição química bastante heterogênea em função da origem das matérias primas constituintes (Fortuny e Fuller, 1979).

Geralmente, o lodo de esgoto é rico em matéria orgânica, N, P, Ca e micronutrientes e deficiente em K. O K é um elemento muito solúvel que não fica retido na matéria orgânica do lodo, se perdendo com o efluente. Assim, durante aplicação de lodos de esgoto para melhorar a fertilidade dos solos, pode ser necessária a complementação com esse nutriente 


\subsubsection{Benefícios da utilização de biossólido}

Segundo a Agência de Proteção Ambiental dos Estados Unidos (U.S. Environmental Protection Agency, 1999), o biossólido (historicamente conhecido como lodo de esgoto) deve ter potencial de uso benéfico, especialmente, como corretivo de solo. Miles et al. (1995) e Arnold et al. (1996), também enfocam o uso benéfico do biossólido. Eles afirmam que o lodo deve ser chamado de biossólido quando seu destino final é o uso benéfico como fertilizante e condicionador de solos, aproveitando seu valor como fonte de nutrientes e matéria orgânica para as plantas. De acordo com Poggiani et al. (2000), a Water Environmental Federation, recomenda o uso do termo biossólido para designar o lodo que passa por um tratamento biológico e que apresenta um potencial de uso benéfico em sistemas agro-florestais, sem apresentar riscos à saúde humana e animal.

Para a aplicação do biossólido em determinada área com fins de uso benéfico, deve-se respeitar certos limites de aplicação que garantam segurança na utilização, evitando possíveis problemas, tais como: presença de microorganismos patogênicos, concentrações elevadas de nitrato e metais pesados, atração de vetores como roedores e moscas. Durante a aplicação deve-se garantir a execução das melhores práticas de manejo. De acordo com Miles et al. (1995), as melhores práticas de manejo são métodos operacionais que determinam características da aplicação de biossólido visando proteger o ambiente. Elas incluem taxas de aplicação agronomicamente corretas, limitações devido à declividade e ao $\mathrm{pH}$ do solo, zonas tampões, restrições quanto ao acesso público, práticas de conservação do solo e outras restrições locais.

Nos Estados Unidos, durante o ano de 1998, $60 \%$ do biossólido produzido teve uso benéfico, sendo $41 \%$ aplicado no solo para favorecer o desenvolvimento da vegetação, incluindo as florestas (USEPA, 1999).

No Estado de São Paulo, foram elaboradas normas para regularizar a utilização do biossólido (Companhia de Tecnologia e Saneamento Ambiental, 
1999). Segundo a norma da CETESB o termo biossólido refere-se exclusivamente ao lodo resultante do sistema de tratamento biológico de despejos liquidos sanitários, com caracteristicas tais que atende as condições da norma para uma utilização segura na agricultura.

A utilização de biossólido propicia um melhor aproveitamento de nutrientes pela planta, visto que os mesmos estão na forma orgânica e são liberados gradativamente, suprindo de modo mais adequado às exigências nutricionais no decorrer do ciclo biológico (Carvalho e Barral, 1981). Desse modo, não se deve dispensar inicialmente uma complementação com fertilizantes minerais, para compensar essa lenta mineralização do biossólido (Vlawis e Willians, 1971).

Do ponto de vista químico, quando o lodo reage com o solo ocorre reações de óxido-redução e interações do tipo ácido-base, aumentando a CTC do solo e enriquecendo-o em cátions básicos ( $\mathrm{Ca}$ e $\mathrm{Mg}$ ), aumentando o $\mathrm{pH}$ e diminuindo o alumínio trocável. Do ponto de vista das propriedades físicas do solo, o biossólido, pelo efeito da matéria orgânica nele contida, reflete em melhoria da estrutura física, aumentando a agregação das partículas (estabilidade de agregados), favorecendo a infiltração de água no perfil, a aeração e a retenção de umidade (Sabey, 1974; Carvalho e Barral, 1981). Após certo tempo, o efeito direto da matéria orgânica contida no biossólido é , normalmente, menor do que o efeito indireto devido à elevação da matéria orgânica do solo causada pelo aumento na proliferação de raizes e na biomassa das plantas.

Vários trabalhos relatam ganhos na produtividade de culturas agrícolas (Bettiol et al., 1982; Boaretto et al., 1992; Ros et al., 1993). Nas atividades agrícolas, com a aplicação do biossólido ao solo ocorre a reciclagem de nutrientes para os vegetais, com economia de fertilizantes, tornando mais sustentável o sistema de produção (Carvalho \& Barral, 1981).

Dentre as várias alternativas de disposição final para o lodo de esgoto gerado nas estações, o uso como biossólido é uma das mais corretas do ponto 
de vista ecológico. Do ponto de vista social, é um importante benefício para as grandes cidades, por criar uma forma de saída para um dos resíduos mais problemáticos gerados nas áreas urbanas.

\subsubsection{Os possíveis problemas}

Os problemas mais associados à utilização de biossólido são, as possiveis concentrações elevadas de metais pesados e presença de microorganismos patogênicos.

Os organismos patogênicos, podem causar doenças tanto nas pessoas que lidam com o material, quanto nas plantas cultivadas. Eles podem ser agrupados em ovos de vermes, bactérias, quistos de protozoários e vírus (FAO, 1978).

As limitações quanto a quantidade de organismos patogênicos são utilizadas para classificar o biossólido como classe "A" ou "B". O biossólido classe " $A$ " passa por processos de higienização que garantem, praticamente a inexistência de patógenos, sendo inclusive liberado seu uso em áreas públicas como praças e jardins.

A presença de poluentes como os metais pesados, está em geral associada à ocorrência de despejos industriais no esgoto. Segundo Berton (2000), os metais pesados são definidos como os elementos químicos com densidade maior que $5 \mathrm{~g} \mathrm{~cm}^{-3}$. Segundo Tiller e Mcbride (1989), o termo metal pesado pode ser uma denominação globalizada, usada para os metais classificados como poluentes ambientais.

Alguns metais pesados são essenciais a plantas, animais e ao homem, tais como zinco $(\mathrm{Zn})$ e cobre $(\mathrm{Cu})$; entretanto, se ingeridos em quantidades elevadas esses elementos apresentam alta toxicidade, colocando em risco a saúde humana e animal (Andrade, 1999).

A ocorrência de problemas com metais vai depender não só da concentração, mas também da espécie química presente, que varia em função de fatores como o pH e o potencial de óxido-redução. 
O efeito a longo prazo dos metais pesados no ambiente não é completamente conhecido e entendido. Através da absorção pelas plantas, que alimentarão os herbivoros, os metais podem entrar na cadeia alimentar, chegando aos consumidores de primeira ordem e ao homem. Segundo Chaney (1990), a captura pelas plantas é a principal maneira dos metais entrarem na cadeia alimentar.

Outro aspecto que nem sempre é considerado, mas de suma importância quando se cogita o uso agronômico do biossólido, diz respeito ao nitrogênio ( $N$ ) aplicado via resíduo. Em função da taxa de mineralização do $N$ (TMN), que é dependente de características do biossólido e características edafoclimáticas do local onde é aplicado, pode haver movimentação de nitrato no perfil do solo e conseqüente contaminação de águas subterrâneas. O comportamento do $\mathrm{N}$ aplicado via resíduos orgânicos, em geral, ou biossólidos, em particular, tem sido pouco estudado em solos ácidos e muito intemperizados (Andrade, 1999).

Vale ressaltar que a aceitação pública da utilização de biossólidos pode ser um grande problema. O biossólido que sai das estações de tratamento normalmente apresenta um aspecto visual e odor desagradáveis. Além disso o repúdio existente pelos nossos próprios dejetos, inexistente para estercos de outros animais, pode comprometer a comercialização de um produto que tenha sido cultivado utilizando biossólido.

\subsubsection{Utilização em florestas}

As alternativas mais usuais para o aproveitamento e/ou destino final de lodos/biossólidos têm sido as seguintes: uso agrícola, disposição em aterro sanitário, reuso industrial, incineração, conversão do lodo em óleo combustível, recuperação de solos, "landfarming" e disposição oceânica (Tsutya, 2000). Esse autor cita o uso em florestas como uma alternativa interessante junto às culturas mais recomendadas (milho, trigo, cana e sorgo), sendo incluído como uso agricola. 
No entanto, a aplicação de biossólido em plantações florestais, apresenta um série de vantagens em comparação com sistemas agrícolas. Hart et al. (1988), citando vários outros autores, resumem essas vantagens. Os produtos das culturas florestais, normalmente não são comestíveis, diminuindo o risco quanto à entrada de possíveis contaminantes na cadeia alimentar. As florestas respondem à aplicação de biossólido com significantes aumentos de nutrientes e biomassa. $O$ ciclo das culturas florestais são mais longos e a acumulação de biomassa durante esse período é uma maneira de armazenar certos elementos perigosos, que podem ser retirados do local com a colheita da madeira. Os solos florestais são geralmente pobres, resultando em melhor aproveitamento e menores perdas dos nutrientes. As florestas oferecem menor oportunidade de contato humano com biossólido recém aplicado. Além disso o ciclo longo das culturas florestais permite maiores intervalos e uma maior dinâmica entre aplicações, aumentando a eficiência de absorção do sistema radicular perene, profundo e bem distribuído das árvores. Dessa maneira, os nutrientes do biossólido, liberados de forma mais lenta, podem ser melhor aproveitados pelas árvores, com menores perdas por lixiviação ou escorrimento superficial.

De maneira geral, tanto na Europa quanto na América do Norte e na Austrália, existem diversas pesquisas com respostas favoráveis das espécies florestais de interesse silvicultural, principalmente, as do gênero Pinus, à adição de biossólido ( McNab e Berry, 1985; Phillips et al., 1986; Hart et al., 1988; Weetman et al., 1993; Polglase e Myers, 1995). Diversos experimentos realizados no estado de Washington (EUA) assinalam que a aplicação do lodo beneficia os sítios florestais através de um resultado imediato que pôde ser constatado pelo crescimento das árvores e da vegetação do sub-bosque e, a longo prazo, pelo aumento da produtividade do sítio (Henry et al., 1994).

Fiskell et al. (1990) relatam baixa concentração de metais em plantio de Pinus elliottii var. elliottii e no sub-bosque, após aplicação de até $22 \mathrm{t} \mathrm{ha}^{-1}$ de biossólido em solo arenoso. Dos metais remanescentes no horizonte orgânico, 
somente zinco e cádmio apresentaram alguma quantidade na forma trocável, sendo que apenas o zinco foi acumulado em quantidade apreciável na planta.

Em Vancouver (Canadá), árvores tratadas com fertilizantes inorgânicos sofreram deficiência de enxofre, enquanto áreas tratadas com lodo de esgoto não apresentaram essa deficiência (Weetman et al., 1993)

Henry et al. (1993) conduziram estudos durante 20 anos em uma floresta experimental localizada em Washington (EUA), confirmando a grande potencialidade de biossólidos para aumentar a produtividade de muitas áreas florestais. Esses estudos mostraram claramente que a aplicação de biossólidos, em quantidades ambientalmente aceitáveis, resulta em elevadas taxas de resposta de crescimento, tanto para plantios jovens, como para áreas bem estabelecidas. A resposta do crescimento à aplicação do biossólido é, tipicamente, maior e mais duradoura quando comparada com fertilização mineral.

Labrecque et al. (1995) aplicaram 6 doses de lodo estabilizado, desidratado e granulado, de forma a obter $0,40,80,120,160$ e $200 \mathrm{~kg} \mathrm{~N}$ disponível ha- ${ }^{-1}$ em grandes potes plásticos contendo solo arenoso e cultivados com duas espécies do gênero Salix durante vinte semanas. A maior dose testada provocou o melhor desenvolvimento, em ambas espécies. $O$ coeficiente de transferência de metais não variou entre espécies, mas foi, significativamente, maior para cádmio e zinco. As plantas absorveram mais cádmio e zinco, mas foram menos hábeis para absorver níquel, mercúrio, cobre e chumbo. Eles afirmam que um conteúdo elevado de metais em culturas agrícolas não é desejável, além de ser potencialmente perigoso. No entanto, para árvores isso é aceitável, desde que a atividade fisiológica não seja afetada. Assim, as plantações florestais podem ser usadas como filtros, através da captura, acúmulo e armazenamento de poluentes dentro da biomassa. Isso vai variar com a cultura florestal, pois existe uma captura seletiva de metais, provavelmente, devido à solubilidades diferentes no solo e preferência de determinada espécie vegetal por diferentes metais. 
Em uma área dos EUA, cultivada com Abies grandis e Pseudotsuga menziesii, oito anos após a aplicação de $300 \mathrm{t} \mathrm{ha}^{-1}$ (peso seco) de biossólido, houve sintomas de deficiência de $\mathrm{Mg}$ (Harrison et al., 1994). Nessa área, apesar dos níveis de metais serem, significativamente, maiores para níquel, cádmio e crômio nas folhas das árvores plantadas na área tratada, as concentrações não atingiram níveis considerados tóxicos.

\subsection{Nutrição mineral de eucalipto}

Apenas a análise de solo é insuficiente para realização do monitoramento do estado nutricional das árvores, pois a existência do nutriente no solo não significa que a planta está sendo adequadamente suprida (Silva et al., 1997). Os mesmos autores relatam que amostras de tecidos vegetais vêm sendo utilizadas para o estudo das relações entre o crescimento e o nível nutricional das plantas. No entanto, é preciso estar atento ao analisar teores foliares de nutrientes e consciente de que existem fatores que não estão ligados ao desenvolvimento da planta que podem alterar esses teores. De acordo com Silveira et al. (2000), o ataque de pragas e doenças, aplicação indevida de defensivos, utilização de conceitos de relações e concentração de nutrientes, material genético e condições ambientais são fatores que podem alterar os teores de nutrientes nas plantas.

Um dos principais fundamentos da diagnose visual e/ou foliar parte da premissa de que é nas folhas que ocorre a maioria dos processos fisiológicos e metabólicos, devendo seu conteúdo mineral estar sempre associado com o desenvolvimento e o aumento da produção (Silveira et al., 2000). Além disso, para o Eucalyptus, vários trabalhos citados por Bellote e Silva (2000), encontraram que a folha é o órgão da planta que mais concentra os nutrientes minerais, exceto $\circ \mathrm{Ca}$, o qual é encontrado em maior concentração na casca.

Segundo Haag (1983), no Brasil, o emprego da análise foliar iniciou-se nos primeiros anos da década de sessenta. As folhas não são a única parte da planta capaz de refletir o estado nutricional das árvores, mas elas vêm sendo 
recomendadas e utilizadas no monitoramento nutricional para a maioria dos elementos.

É notável a capacidade que tem o eucalipto de se desenvolver em sitios de baixa fertilidade, devido à sua eficiência para extrair nutrientes do solo. Grove et al. (1996), explicam que baixas e variáveis concentrações de nutrientes nos solos têm exercido forte pressão de seleção na evolução dos eucaliptos. A sobrevivência e crescimento de eucaliptos nesses solos pobres em nutrientes se devem ao desenvolvimento de mecanismos que controlam a captura de nutrientes, os quais contribuem para seu uso eficiente e retenção dentro da árvore.

Segundo Wadt e Novais (1997), três estádios nutricionais podem ser distinguidos nos povoamentos florestais: o estádio I, antes do fechamento das copas, que caracteriza-se por elevadas taxas de crescimento e absorção de nutrientes; o estádio II, onde ocorre o fechamento das copas e a queda de folhas, dando início ao processo de ciclagem bioquímica e biogeoquímica e o estádio III, onde processos de imobilização podem diminuir a contribuição dos processos de ciclagem, aumentando a demanda por novos inputs de nutrientes no sistema.

Segundo Gonçalves et al. (1996), as faixas de teores considerados adequados, na matéria seca de folhas de plantas adultas de Eucalyptus são:

$\mathrm{N}\left(13-18 \mathrm{~g} \mathrm{~kg}^{-1}\right), \mathrm{P}\left(0,9-1,3 \mathrm{~g} \mathrm{~kg}^{-1}\right), \mathrm{K}\left(9-13 \mathrm{~g} \mathrm{~kg}^{-1}\right), \mathrm{Ca}\left(6-10 \mathrm{~g} \mathrm{~kg}^{-1}\right), \mathrm{Mg}(3,5-5,0$ $\left.\mathrm{g} \mathrm{kg}^{-1}\right), \mathrm{S}\left(1,5-2,0 \mathrm{~g} \mathrm{~kg}^{-1}\right), \mathrm{B}\left(30-50 \mathrm{mg} \mathrm{kg}^{-1}\right), \mathrm{Cu}\left(7-10 \mathrm{mg} \mathrm{kg}{ }^{-1}\right)$, Mo $(0,5-1,0 \mathrm{mg}$ $\left.\mathrm{kg}^{-1}\right)$, Fe (150-200 mg kg-1), Mn (400-600 mg kg-1) e Zn (35-50 mg kg-1).

Novais et al. (1990), afirmam que a nutrição de plantas é um processo dinâmico, que não pode ser entendido na sua totalidade com uma simples avaliação de laboratório da fertilidade de um solo ou pela análise de parte da planta, em um dado momento, num processo estático, incompleto, quando comparado ao crescimento de uma planta, que reflete a ação de uma série de fatores num processo dinâmico. Assim, devem ser realizadas várias análises ao 
longo do desenvolvimento da planta, procurando entender esse aspecto dinâmico da absorção dos nutrientes e sua relação com o crescimento.

Normalmente, os eucaliptos são plantados em sítios de baixa fertilidade, o que leva à necessidade de fornecer nutrientes via fertilização mineral para se atingir teores adequados nas plantas e uma boa nutrição do povoamento. Gonçalves et al. (1996), baseados em tabelas de interpretação de análise de solo, apresentam recomendação de fertilizantes minerais para a cultura de eucalipto. Considerando as situações mais deficientes de matéria orgânica, teor de argila, $\mathrm{P}$ e $\mathrm{K}$ no solo, os autores recomendam doses extremas de $60 \mathrm{~kg} \mathrm{ha}^{-1}$ de $\mathrm{N}, 120 \mathrm{~kg} \mathrm{ha}^{-1}$ de $\mathrm{P}_{2} \mathrm{O}_{5}$ e $80 \mathrm{~kg} \mathrm{ha}^{-1}$ de $\mathrm{K}_{2} \mathrm{O}$.

\subsection{Ciclagem de nutrientes}

Segundo Poggiani et al. (2000), a sustentabilidade de uma plantação florestal está diretamente relacionada, além de outros fatores, com o balanço nutricional do ecossistema. Em outras palavras, a médio e longos prazos, a quantidade de nutrientes para o crescimento das árvores, que entra na plantação florestal, deve ser equivalente à quantidade que sai do ecossistema devido à colheita florestal, à lixiviação e aos processos erosivos. Se este balanço não for estabelecido, não haverá sustentabilidade a longo prazo.

O balanço entre a entrada e a saída de nutrientes de um ecossistema é estimado através da quantificação dos processos que ocorrem no ciclo geoquímico. Este ciclo caracteriza-se pelas trocas de elementos minerais entre um determinado ecossistema e seus componentes externos. As principais fontes de entrada de nutrientes no ecossistema florestal são: a poeira, a chuva, o intemperismo das rochas, a fixação biológica de nitrogênio e a aplicação de fertilizantes e resíduos orgânicos urbanos ou agroindustriais. Neste ciclo, as perdas de nutrientes são ocasionadas pelos processos de erosão e lixiviação, pela água de drenagem, fogo, processos de denitrificação e principalmente pela colheita florestal (Vital, 1996; Poggiani e Schumacher, 1997). 
Para se entender os processos de ciclagem biogeoquímica em um ecossistema florestal, além de conhecer os processos de entrada e perda de nutrientes no ecossistema, é preciso compreender as transformações internas que acontecem. A floresta modifica a química da precipitação quando ela passa através das copas ou escorre pelos troncos das árvores. Além disso, ocorre a transformação da manta florestal (serapilheira), cuja decomposição, assim como, das raizes e organismos, libera novamente os nutrientes tornando-os disponíveis para as plantas, através da mineralização da matéria orgânica do solo.

A quantidade de nutrientes na serapilheira depende da espécie, da proporção de folhas em relação aos outros componentes, da ciclagem bioquímica (capacidade de translocação dos nutrientes dentro da árvore antes da senescência e queda das folhas), bem como do tipo de solo (Schumacher e Poggiani, 1993).

A retranslocação de nutrientes de tecidos senescentes para os tecidos mais jovens da árvore pode suprir grande parte de sua demanda nutricional, especialmente, por nutrientes móveis dentro da planta, como: N, S, P e K, diretamente envolvidos na dinâmica dos processos fisiológicos (Landsberg e Gower, 1997).

Os nutrientes, uma vez introduzidos no ecossistema podem reciclar por tempo mais ou menos prolongado, dependendo da eficiência da ciclagem bioquímica e biogeoquímica. Quanto mais prolongado o tempo de reciclagem, mais conservativo pode ser considerado o ecossistema. 
O diagrama da Figura 1 ilustra o processo de ciclagem de nutrientes em um ecossistema florestal.

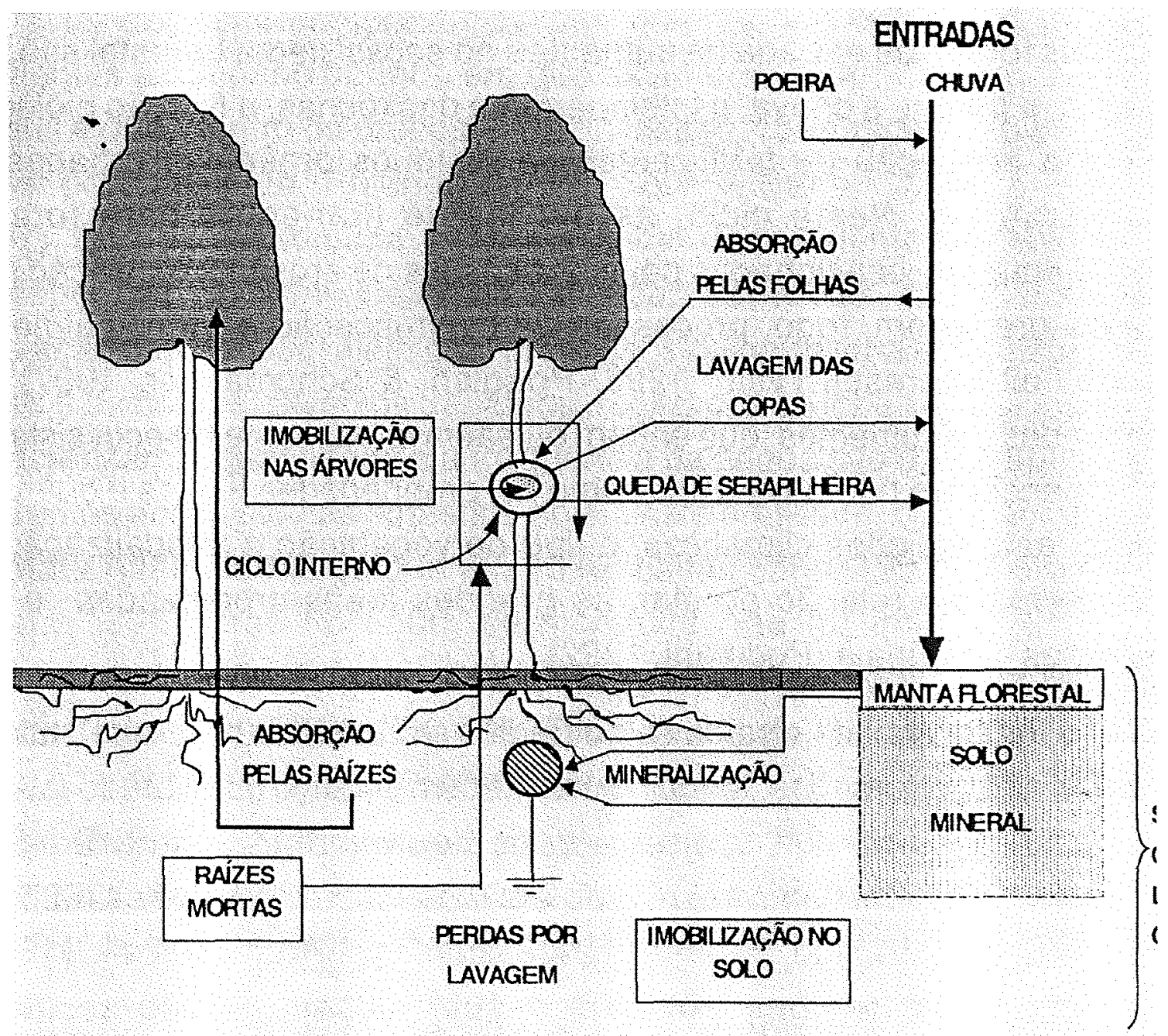

Figura 1. Esquema da dinâmica de nutrientes em um ecossistema florestal (Poggiani et al., 2000; adaptado de Miller, 1984) 
No esquema anterior as entradas de nutrientes no ciclo geoquímico são representadas pela chuva, poeira e reabastecimento pelo solo mineral; as saídas pelas perdas por lixiviação. Considerando o ciclo biogeoquímico, as entradas ocorrem através da lavagem das copas durante precipitação interna e através do reabastecimento pela mineralização da matéria orgânica proveniente da queda de serapilheira e de raízes mortas. Após absorção pelas raízes parte dos nutrientes são imobilizados na biomassa, ocorrendo o ciclo interno ou retranslocação dos elementos móveis dentro das árvores (ciclo bioquímico). 


\section{MATERIAL E MÉTODOS}

\subsection{Descrição da área experimental}

\subsubsection{Situação geográfica}

A Estação Experimental de Ciências Florestais de Itatinga, vinculada ao Departamento de Ciências Florestais da Escola Superior de Agricultura Luiz de Queiroz, localiza-se no município de Itatinga - SP. Ela fica localizada entre os paralelos $23^{\circ} 02^{\prime} 01^{\prime \prime}$ e $23^{\circ} 02^{\prime} 30^{\prime \prime}$ latitude sul e os meridianos $48^{\circ} 37^{\prime} 30^{\prime \prime}$ e $48^{\circ}$ 38' 34" longitude oeste de Greenwich, com altitude média de $830 \mathrm{~m}$. A estação fica distante, aproximadamente, $170 \mathrm{~km}$ da cidade de Piracicaba e $220 \mathrm{~km}$ da cidade de São Paulo.

\subsubsection{Plantio e tratos silviculturais no talhão experimental}

A área do talhão experimental era ocupada por um povoamento de Eucalyptus saligna com idade aproximada de cinquenta anos e submetido a vários ciclos de corte. Para implantar este experimento, a madeira foi colhida e a área reformada com mudas originadas de sementes de Eucalyptus grandis, em março de 1998, no sistema de cultivo mínimo.

Foi realizada capina química, a base de glifosato, 1 mês após o plantio e roçada manual 13 meses após. O controle de formigas cortadeiras foi realizado com iscas formicidas, a base de sulfluramida, pré e pós-implantação. Um ano após o plantio foi aplicado fungicida Bayfidan $\left(2 \mathrm{~kg} \mathrm{ha}^{-1}\right)$ para controle de ferrugem. 


\subsubsection{Clima}

O clima local é do tipo CWa, segundo classificação de Köppen; ou seja, mesotérmico úmido com invernos secos. Os dados metereológicos coletados no período experimental, mostram que o valor mais baixo da temperatura mínima média mensal foi de $8{ }^{\circ} \mathrm{C}$ e que o valor mais alto da temperatura máxima média mensal foi de $31^{\circ} \mathrm{C}$. Durante os 25 meses do período, a média das mínimas foi de $13{ }^{\circ} \mathrm{C}$ e das máximas $27^{\circ} \mathrm{C}$. A umidade relativa média mensal foi de $89 \%$ e a precipitação total nos 25 meses foi de $2471 \mathrm{~mm}$. Durante todo o ano de 1999 choveu $1230 \mathrm{~mm}$.

A seguir são apresentados os dados climáticos coletados na estação metereológica situada na estação experimental (Figura 2).

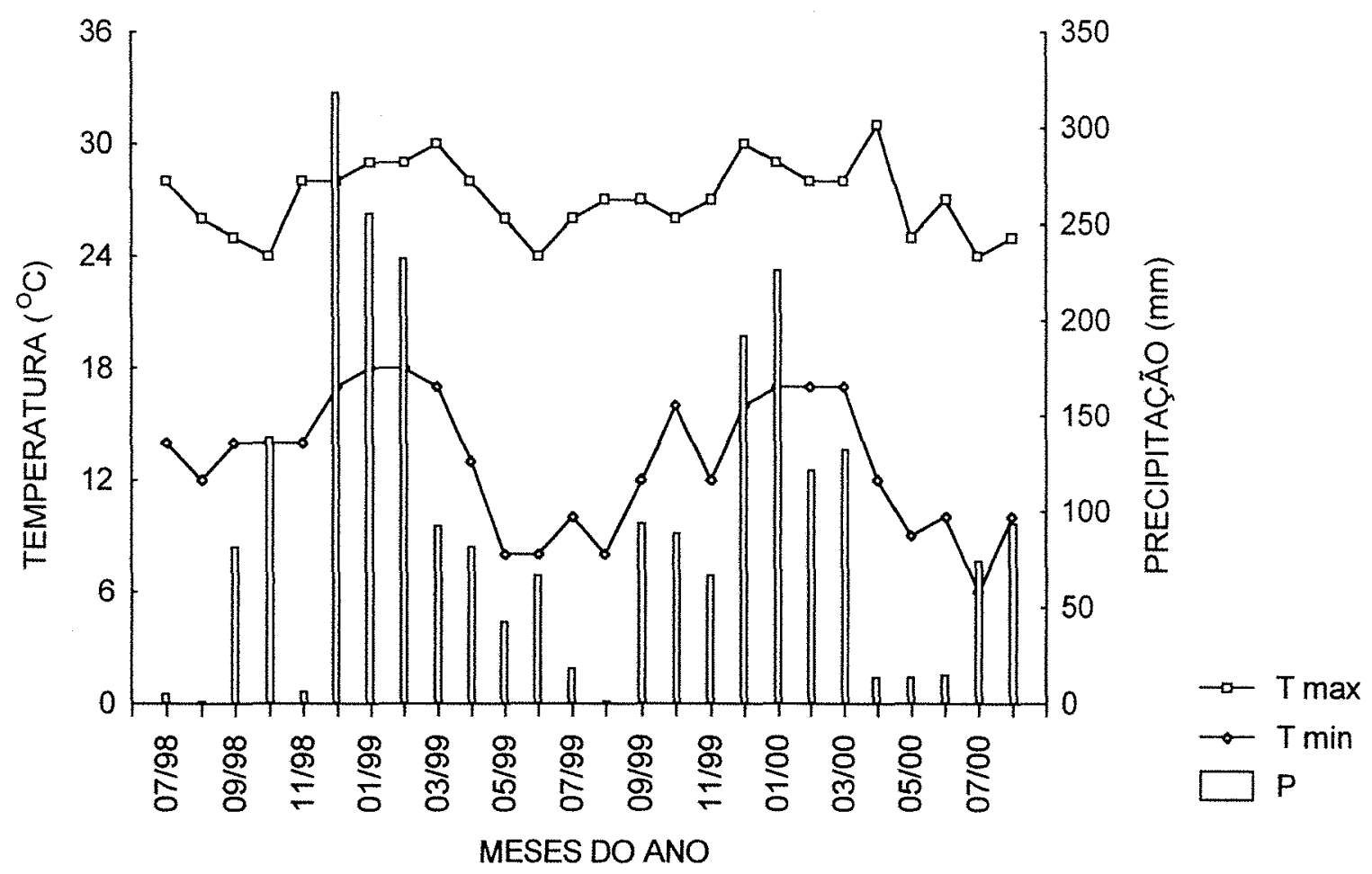

Figura 2. Médias mensais da temperatura máxima ( $T$ max) e temperatura mínima (T min) e valores de precipitação pluviométrica $(P)$ acumulados no mês, durante o período experimental. 


\subsubsection{Solos e vegetação}

Vaz (2000), que trabalhou na mesma área experimental, analisando o efeito do biossólido sobre a fertilidade do solo, apresenta a caracterização inicial do solo antes da implantação do experimento (Tabela 2). O solo da área experimental é um Latossolo Vermelho-Amarelo, suavemente ondulado, com baixos teores de nutrientes. Esse tipo de solo é um dos mais representativo das áreas onde, hoje, se pratica a silvicultura com eucalipto no Estado de São Paulo. 
Tabela 2. Caracterização química e física do solo da área experimental, em diversas profundidades (Prof.). Segundo Vaz (2000).

\begin{tabular}{|c|c|c|c|c|c|c|c|c|c|c|c|c|}
\hline Prof. & $\mathrm{pH}$ & MO & $\mathbf{P}$ & $\mathrm{K}$ & $\mathbf{C a}$ & $\mathrm{Mg}$ & $\mathrm{H}+\mathrm{Al}$ & $\overline{A l}$ & SB & $T$ & V & $\bar{m}$ \\
\hline $\mathrm{cm}$ & & $\mathrm{g} \mathrm{dm}^{-3}$ & $\mathrm{mg} \mathrm{dm^{-3 }}$ & $\cdots$ & $\cdots$ & 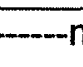 & $\mathrm{mol}_{\mathrm{c}} \mathrm{dm}^{-3}$ & & & 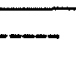 & $\%$ & $\%$ \\
\hline $0-5$ & 3,6 & 56 & 2 & 0,9 & 3 & 2 & 92 & 19 & 6 & 98 & 6 & 79 \\
\hline $5-10$ & 3,8 & 18 & 1 & 0,9 & 2 & 2 & 53 & 12 & 5 & 58 & 9 & 68 \\
\hline \multirow[t]{2}{*}{$10-20$} & 3,8 & 15 & 1 & 0,9 & 4 & 1 & 45 & 10 & 6 & 51 & 12 & 65 \\
\hline & \multicolumn{2}{|c|}{$\mathrm{Cu}$} & $\mathrm{Zn}$ & & \multicolumn{2}{|l|}{ Mn } & $\mathrm{Fe}$ & \multicolumn{3}{|c|}{$\mathrm{S}^{-\mathrm{SO}_{4}{ }^{2-}}$} & \multicolumn{2}{|c|}{ B } \\
\hline $0-5$ & \multicolumn{2}{|c|}{0,5} & 0,5 & & \multicolumn{2}{|c|}{2,4} & 123 & \multicolumn{3}{|c|}{12,8} & \multicolumn{2}{|c|}{0,2} \\
\hline $5-10$ & \multicolumn{2}{|c|}{0,6} & 0,3 & & \multicolumn{2}{|c|}{0,5} & 76 & \multicolumn{3}{|c|}{13,9} & \multicolumn{2}{|c|}{0,2} \\
\hline $10-20$ & \multicolumn{2}{|c|}{0,7} & 0,3 & & \multicolumn{2}{|l|}{0,4} & 67 & \multicolumn{3}{|c|}{26,6} & \multicolumn{2}{|c|}{0,2} \\
\hline
\end{tabular}

*Análise realizada segundo metodologia apresentada por Raij et al. (1987).

\begin{tabular}{cccccc}
\hline Prof & \multicolumn{3}{c}{ Areia } & Silte & Argila \\
\cline { 2 - 3 } & grossa & fina & Total & & \\
\hline $\mathrm{cm}$ & -0 & & & \\
$0-30$ & 532 & 241 & 773 & 59 & 168 \\
$30-60$ & 495 & 266 & 761 & 49 & 190 \\
$60-90$ & 496 & 278 & 774 & 29 & 197 \\
\hline
\end{tabular}

* Análise realizada segundo metodologia apresentada por Camargo et al. (1986).

A vegetação natural da região é o cerrado, sendo que a maior parte da estação era ocupada por cerrado sensu stricto. Atualmente, existem algumas manchas desse tipo de vegetação, mas predominam culturas florestais de eucaliptos e pinheiros.

\subsection{Caracterização e aplicação do biossólido}

O material utilizado no experimento foi proveniente da estação de tratamento de esgoto (ETE) de Barueri, região metropolitana de São Paulo. A 
SABESP foi responsável pela caracterização físico-química e manutenção da qualidade do lodo enviado, dentro do estabelecido pela norma norte-americana 40 CFR Part 503 elaborada pela agência de proteção ambiental dos Estados Unidos (U.S.E.P.A., 1984).

O biossólido aplicado na área experimental foi produzido após tratamento biológico dos esgotos (digestão aeróbia utilizando ar difuso durante a fase de decantação e digestão anaeróbia dos lodos primários e secundários) seguido de condicionamento químico $\left(\mathrm{FeCl}_{3}\right.$ e $\left.\mathrm{CaOH}_{2}\right)$ e desidratação na fase final. Atualmente, a ETE de Barueri eliminou o condicionamento químico do processo de tratamento, passando a utilizar polímeros e produzir lodo com características distintas das aqui apresentadas.

O material utilizado possuía densidade de coliformes fecais inferior a $2 \mathrm{x}$ $10^{-6} \mathrm{NMP} \mathrm{g} \mathrm{ST}^{-1}$ (Número Mais Provável por grama de Sólidos Totais), sendo caracterizado como biossólido tipo B (CETESB, 1999); já que o processo de estabilização com cal é aceito pelo órgão controlador como eficiente na redução de patógenos e a densidade dos organismos indicadores ficou abaixo do limite permitido. $O$ biossólido apresentou a seguinte composição (Tabela 3 ):

Tabela 3. Caracterização do biossólido utilizado no experimento (elementos totais, base seca $-65^{\circ} \mathrm{C}$ ), produzido pela Estação de Tratamento de Esgoto de Barueri.

\begin{tabular}{cccc}
\hline Elemento & Concentração & Elemento & Concentração \\
\hline $\mathrm{C}\left(\mathrm{g} \mathrm{kg}^{-1}\right)$ & 172,0 & $\mathrm{Cu}\left(\mathrm{mg} \mathrm{kg}^{-1}\right)$ & 900 \\
$\mathrm{~N}\left(\mathrm{~g} \mathrm{~kg}^{-1}\right)$ & 26,6 & $\mathrm{Fe}\left(\mathrm{mg} \mathrm{kg}^{-1}\right)$ & 39200 \\
Relação C:N & 4,3 & $\mathrm{Zn}\left(\mathrm{mg} \mathrm{kg}^{-1}\right)$ & 1500 \\
$\mathrm{P} \quad\left(\mathrm{g} \mathrm{kg}^{-1}\right)$ & 9,5 & $\mathrm{Mn}\left(\mathrm{mg} \mathrm{kg}^{-1}\right)$ & 300 \\
$\mathrm{~K}\left(\mathrm{~g} \mathrm{~kg}^{-1}\right)$ & 1,3 & $\mathrm{Na}\left(\mathrm{g} \mathrm{kg}^{-1}\right)$ & 0,5 \\
$\mathrm{Ca}\left(\mathrm{g} \mathrm{kg}^{-1}\right)$ & 95,0 & $\mathrm{Cd}\left(\mathrm{mg} \mathrm{kg}^{-1}\right)$ & 21 \\
$\mathrm{Mg}\left(\mathrm{g} \mathrm{kg}^{-1}\right)$ & 3,0 & $\mathrm{~Pb}\left(\mathrm{mg} \mathrm{kg}^{-1}\right)$ & 200 \\
$\mathrm{~S}\left(\mathrm{~g} \mathrm{~kg}^{-1}\right)$ & 6,0 & $\mathrm{pH} \mathrm{em} \mathrm{CaCl}$ & 10,6 \\
\hline
\end{tabular}


Para estimar o conteúdo de nutrientes $\left(\mathrm{kg} \mathrm{ha}^{-1}\right)$, potencialmente, existentes no biossólido, basta multiplicar o teor de cada nutriente acima $\left(\mathrm{g} \mathrm{kg}^{-1}\right)$ pela dose de aplicação ( $\mathrm{tha}^{-1}$ ). Por exemplo, aplicando-se uma dose de 10 tha' ${ }^{1}$, são introduzidos na área de um hectare $266 \mathrm{~kg}$ de N, $95 \mathrm{~kg}$ de P e $13 \mathrm{~kg}$ de $\mathrm{K}$.

É importante ter consciência de que pode existir grande variação na composição final do biossólido em função dos diferentes processos de tratamento e ter conhecimento das características e do tratamento que o originou.

Para distribuir o biossólido que apresentava por volta de $60 \%$ de umidade, em julho de 1998, foi utilizada uma carreta com capacidade de $3 \mathrm{~m}^{3}$ puxada por um trator. $O$ biossólido foi aplicado à lanço, em cobertura, entre as linhas de plantio (faixa de $2 \mathrm{~m}$ ), deixando, aproximadamente, meio metro de distância das mudas. Havia um receio inicial de que o biossólido, se aplicado no sulco de plantio junto às mudas, poderia prejudicar a sobrevivência e o desenvolvimento das mesmas.

\subsection{Delineamento experimental e tratamentos}

$O$ experimento foi implantado em blocos casualizados, definidos em função da declividade da área. Foram aplicados 9 tratamentos com 4 repetições, totalizando 36 parcelas. Cada parcela possui $600 \mathrm{~m}^{2}(30 \times 20)$ e foi constituída por 10 linhas de $20 \mathrm{~m}$ de comprimento cada. Na linha as plantas foram espaçadas de $2 \mathrm{~m}$ e nas entrelinhas em $3 \mathrm{~m}$, totalizando 100 plantas por parcela. A posição das parcelas dentro de cada bloco foi definida por sorteio. A área útil da parcela considerou as 36 plantas centrais, descontando-se a bordadura dupla, ou seja, uma área efetiva de amostragem de $150 \mathrm{~m}^{2}$.

Os tratamentos aplicados foram:

1) testemunha absoluta (tt), sem adubação e sem aplicação de biossólido;

2) adubação mineral (ad), conforme descrito por Vaz (2000): 1,5 $\mathrm{t} \mathrm{ha}^{-1} \mathrm{de}$ calcário dolomítico (a lanço em área total), $110 \mathrm{~kg} \mathrm{ha}^{-1}$ de $0-45-0$ (sulco de 
plantio), $150 \mathrm{~kg} \mathrm{ha}^{-1}$ de 10-20-10 (sulco de plantio), $80 \mathrm{~kg} \mathrm{ha}^{-1}$ de 20-0-20 (45 dias pós-plantio aplicado em meia lua ao redor da muda), $180 \mathrm{~kg} \mathrm{ha}^{-1}$ de $16-0$ $32+0,3 \% \mathrm{~B}+0,5 \%$ de $\mathrm{Zn}$ ( 6 meses pós plantio aplicado numa faixa de $40 \mathrm{~cm}$ na entrelinha de plantio) e $240 \mathrm{~kg} \mathrm{ha}^{-1}$ de $16-0-32+0,3 \% \mathrm{~B}+0,5 \%$ de $\mathrm{Zn}$ (12 meses pós-plantio aplicado numa faixa de $40 \mathrm{~cm}$ na entrelinha de plantio);

3) $5 \mathrm{t} \mathrm{ha}^{-1}$ de biossólido complementado com $\mathrm{K}(5+\mathrm{K})$;

4) $10 \mathrm{t} \mathrm{ha}^{-1}$ de biossólido complementado com $\mathrm{K}(\mathbf{1 0 + K})$;

5) apenas 10 t ha $^{-1}$ de biossólido (10);

6) 10 t ha $^{-1}$ de biossólido complementado com K e $\mathrm{P}$ na base (10+KP);

7) $15 \mathrm{t} \mathrm{ha}^{-1}$ de biossólido complementado com $\mathrm{K}(15+\mathrm{K})$;

8) 20 tha $^{-1}$ de biossólido complementado com K $(20+K) \mathrm{e}$

9) 40 t ha $^{-1}$ de biossólido complementado com K $(40+K)$.

As doses de biossólido foram calculadas em base seca. No entanto, o material foi aplicado úmido. Assim, por exemplo, uma dose de $10 \mathrm{t} \mathrm{ha}^{-1}$ (base seca), corresponde a $25 \mathrm{t} \mathrm{ha}^{-1}$ de material com $60 \%$ de umidade.

A complementação com $\mathrm{K}$ mineral $\left(\mathrm{KCl}, 60 \%\right.$ de $\left.\mathrm{K}_{2} \mathrm{O}\right)$ foi necessária porque o teor desse elemento no biossólido é baixo, assim como no solo da área experimental. $\mathrm{O} \mathrm{KCl}$ foi colocado em cada tratamento onde foi aplicado biossólido, de acordo com a dose, até igualar a quantidade de $\mathrm{K}$ colocada no tratamento "ad" (125 kg ha-1). Desse modo, com o aumento da dose de biossólido foi colocado menos $\mathrm{K}$ mineral.

Para a suplementação de $P$ no tratamento "10+KP", utilizou-se $80 \mathrm{~kg} \mathrm{ha}^{-1}$ de 0-45-0 aplicado no sulco do plantio.

A dose máxima de biossólido aplicada, $40 \mathrm{t} \mathrm{ha}^{-1}$, foi definida em função do elevado teor de $\mathrm{Ca}$, devido ao processo de tratamento do esgoto, que poderia causar desequilibrios nutricionais. Outros fatores, como teor e taxa de mineralização do $\mathrm{N}$ e teores de metais pesados, também foram considerados.

O monitoramento nutricional foi realizado em todos os tratamentos. No entanto, os estudos referentes à ciclagem dos nutrientes foram efetuados em apenas cinco tratamentos (" $t$ ", "ad", " $10+K P$ ", " $20+K$ " e " $40+K$ ") e os referentes 
ao desenvolvimento do sub-bosque em apenas quatro ("tt", "10+K", "20+K" e " $40+K$ "), já que as coletas envolvidas nesses estudos são muito mais trabalhosas. Além disso, verificou-se na avaliação nutricional que a interpretação dos resultados de nove tratamentos, na maioria das vezes, tornase difícil, sendo que alguns tratamentos trazem poucas informações adicionais para a interpretação dos fenômenos observados.

\subsection{Dados referentes ao crescimento do eucalipto}

Deve ser assinalado que os dados apresentados nesse item não constituem um resultado deste trabalho. Eles são aqui mencionados como referencial para melhor interpretar os dados obtidos sobre a ciclagem de nutrientes.

$\mathrm{Na}$ fase inicial de desenvolvimento, aos 10 meses de idade, as plantas que mais cresceram em altura, foram as plantadas nas parcelas dos tratamentos "10+KP" e "ad" (Figura 3). O adubo mineral, principalmente o fósforo, aplicado nesses tratamentos é prontamente disponivel, o que determinou uma resposta imediata das plantas.

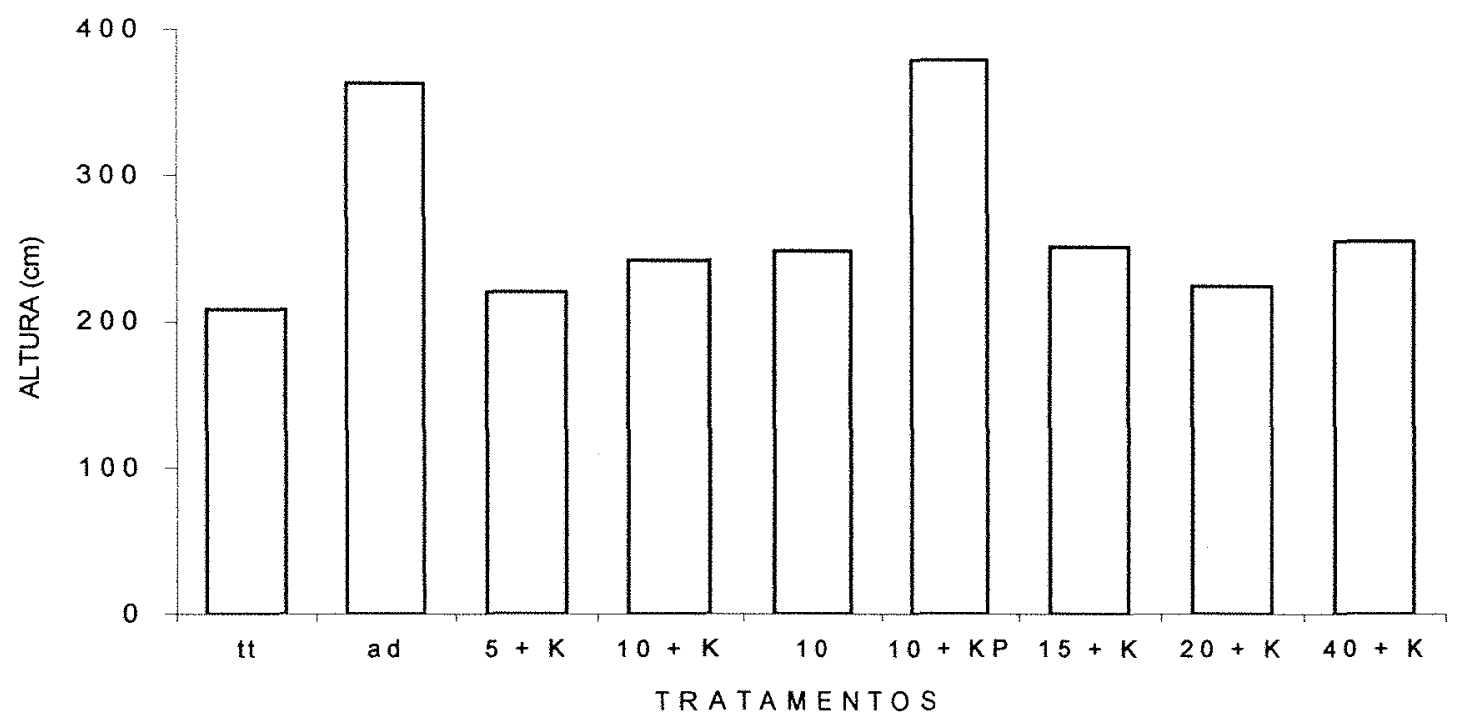

Figura 3. Altura média das plantas de eucalipto, 10 meses após plantio e seis meses após aplicação do biossólido, nos nove tratamentos testados. Dados obtidos de Gonçalves et al. (1999 a). 
Com o passar do tempo, a aplicação de biossólido, cujos nutrientes são liberados mais lentamente, começou a surtir efeito. Aos 18 meses (Jan-00) após aplicação do resíduo, as plantas do tratamento " $40+K "$ que receberam a maior dose de biossólido, apresentaram volume igual às que receberam adubação mineral convencional (ad), sendo superadas apenas pelas do tratamento "10+KP" (Figura 4).

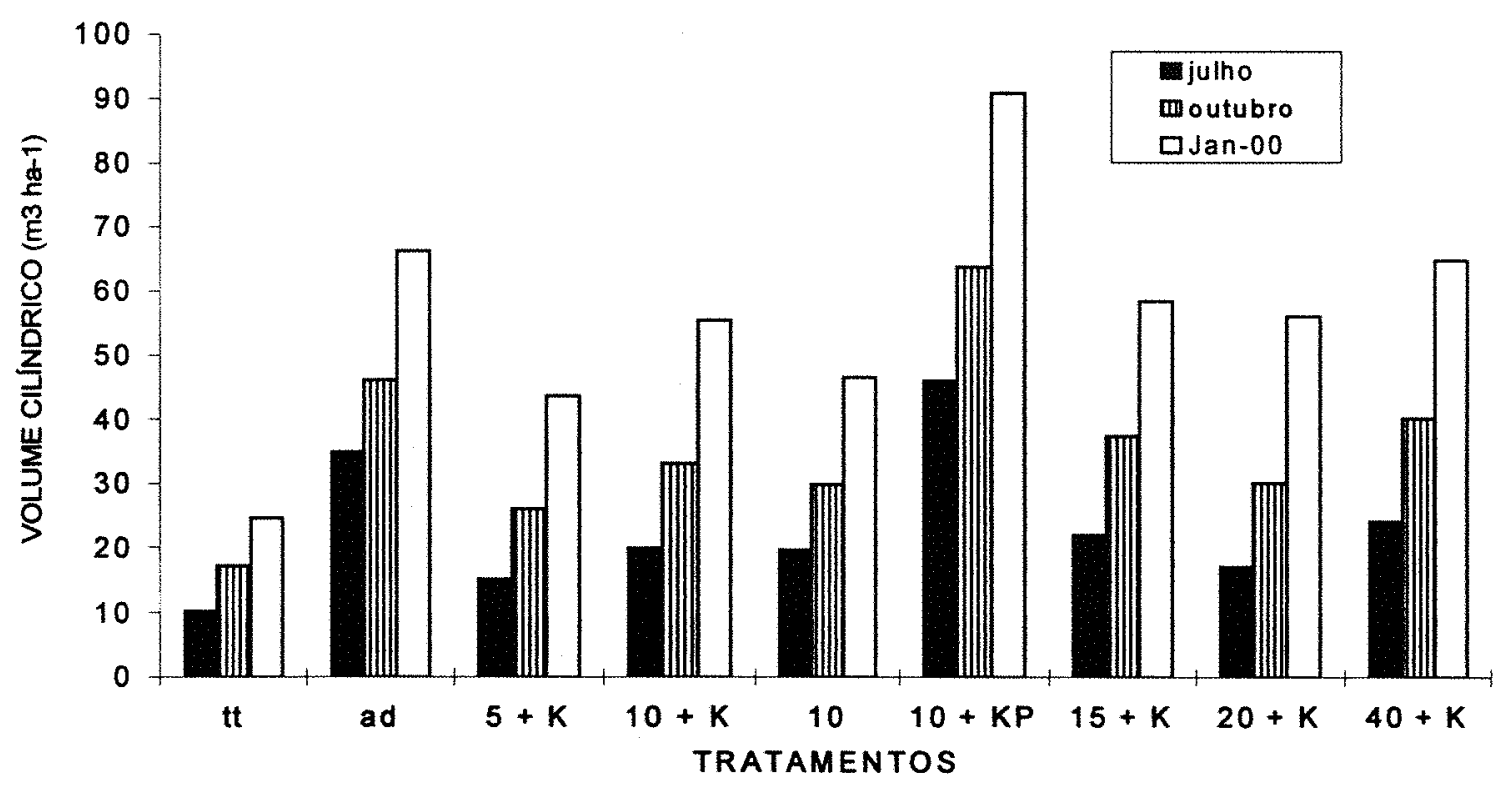

Figura 4. Valores médios $(N=4)$ do volume cilíndrico das árvores de eucalipto, medidas em julho-99, outubro-99 e janeiro-00. Nessas datas as plantas apresentavam, respectivamente, 14, 18 e 22 meses de idade. Dados obtidos de Gonçalves et al. (2000 b) 


\subsection{Coleta das amostras e metodologia de análise}

\subsubsection{Folhas das copas dos eucaliptos}

Aos 2, 4, 6, 8, 12, 16 e 20 meses após a aplicação do biossólido (julho de 1998), foram coletadas folhas maduras do terço superior das copas das plantas, evitando-se colher folhas muito novas ou em processo de senescência, para avaliar o estado nutricional das árvores.

Dentro da área útil de cada parcela, em todos os tratamentos, foram coletadas, folhas de dez árvores. As quatro coletas iniciais foram realizadas manualmente, aos $6,8,10$ e 12 meses após plantio, pois as mudas ainda jovens apresentavam porte baixo. Nas outras coletas, como as plantas já possuíam um porte elevado, foi necessário utilizar um podão.

Para analisar a concentração de nutrientes, as folhas incluindo os pecíolos foram secas a $65^{\circ} \mathrm{C}$, em estufas de ventilação forçada e moídas em moinho tipo Wiley (peneira de 20 mesh). As análises químicas dos elementos (N, P, K, Ca, Mg, S, Fe, Cu, Mn, Zn, Na e B) contidos no material vegetal, foram realizadas após digestão sulfúrica $(N)$, digestão seca $(B)$ e nitricoperclórica (demais elementos) no laboratório de Ecologia Aplicada do Departamento de Ciências Florestais, da Escola Superior de Agricultura "Luiz de Queiroz". O P e o B foram determinados por colorimetria, o teor de N pelo método micro-Kjeldhal, o $\mathrm{K}$ e Na por fotometria de chama, o $\mathrm{S}$ por turbidimetria e os demais elementos por espectrofotometria de absorção atômica, conforme descrito por Malavolta et al. (1997).

\subsubsection{Amostras do folhedo produzido, acumulado e decomposto}

Os estudos envolvendo a ciclagem de nutrientes via folhedo (deposição, acúmulo e decomposição), foram realizados nos tratamentos "tt", "ad", "10+ $K P ", " 20+K "$ e " $40+K "$.

Como o povoamento é jovem, ainda não se observa a queda de frutos, flores, casca, galhos ou troncos. Dessa maneira, nesse experimento optou-se 
por estudar apenas o folhedo, justificando o uso deste termo em vez de serapilheira.

A coleta do folhedo depositado iniciou-se em setembro de 1999 e foi realizada mensalmente. Os coletores foram construídos com bordas de madeira que prendem uma tela de nylon (malha de $2 \mathrm{~mm}$ ) e são fixadas sobre quatro piquetes. A tela é disposta em forma de bolsa côncava e fica suspensa, aproximadamente, $50 \mathrm{~cm}$ acima do solo. As bordas laterais dos coletores possuem $8 \mathrm{~cm}$ de altura e a área interna do coletor é de $0,3249 \mathrm{~m}^{2}(0,57 \mathrm{x}$ $0,57)$. Os coletores foram dispostos entre as linhas de plantio. No centro da área útil da parcela, foram colocados três coletores em diagonal, totalizando 12 repetições para cada tratamento. As amostras dos três coletores de cada parcela foram homogeinizadas e moídas, formando uma amostra composta por parcela, para realização das análises químicas dos nutrientes, conforme metodologia citada anteriormente. Essas análises foram realizadas em duas épocas (11/99 e 03/00).

Para coletar o folhedo acumulado sobre o solo (manta florestal) foi utilizado um coletor quadrado de $0,25 \mathrm{~m}^{2}$. Foram coletadas três amostras por parcela seguindo a linha diagonal da área útil, na primeira coleta, e linhas paralelas a ela nas outras, para evitar que se amostrasse o mesmo local, totalizando doze repetições por coleta para cada tratamento. Foram realizadas quatro coletas nas seguintes datas: 08/99, 02/00, 05/00 e 08/00.

Tanto do folhedo depositado quanto do acumulado, foram descartados outros tipos de materiais que não fossem as folhas de eucalipto.

Usando os dados das avaliações acima, foi calculada a taxa de decomposição instantânea definida por Olson (1963):

$K=L X s s^{-1}$, onde:

$\mathrm{L}=$ quantidade de folhedo produzida por ano $\left(\mathrm{kg} \mathrm{ha}^{-1}\right) \mathrm{e}$

Xss = média de 4 amostras do folhedo acumulado sobre o solo $\left(\mathrm{kg} \mathrm{ha}^{-1}\right) \mathrm{em}$ diferentes épocas do ano. 
A partir da equação anterior, foi calculado o tempo médio de renovação $(T)=1 K^{-1}$. Também pode-se estimar o período de meia vida de uma determinada quantidade de folhedo, assumindo que o modelo para uma fração constante de perda de peso é expresso por uma função exponencial negativa $\left[\mathrm{t}_{0,5}=(-\ln 0,5) \mathrm{K}^{-1}\right]$.

\subsubsection{Amostras da biomassa epígea do sub-bosque}

Durante os meses de março e novembro de 1999 e março de 2000, respectivamente, 8,16 e 20 meses após a aplicação do biossólido, foram coletadas amostras da biomassa epígea do sub-bosque do povoamento de eucalipto. A área útil de cada parcela $\left(150 \mathrm{~m}^{2}\right)$ foi dividida em 10 sub-parcelas de $15 \mathrm{~m}^{2}(3 \times 5 \mathrm{~m})$ e 3 delas foram sorteadas, sem reposição, para cada época de coleta. Assim, a sub-parcela onde o sub-bosque foi coletado uma vez não mais foi amostrada.

A biomassa vegetal do sub-bosque foi coletada nos tratamentos " $\mathrm{tt}$ ", "10 $+K ", 20+K "$ e "40 + K". Foram separadas a parte aérea de gramíneas (monocotiledôneas, principalmente da familia Gramineae) das não gramineas (dicotiledôneas, incluindo espécies herbáceas, arbustivas e mudas de árvores). Foram avaliados a produção de biomassa e o estado nutricional das plantas. Para a análise química dos nutrientes, conforme metodologia já descrita anteriormente, juntou-se 0 material das três sub-parcelas para fazer uma amostra composta por parcela. Para tal finalidade, todo o material vegetal das três sub-amostras foi passado no moinho e do pó resultante foi retirada uma amostra menor para levar ao laboratório

\subsubsection{Luz incidente no sub-bosque}

A luminosidade foi medida utilizando-se um luxímetro Quantum, que detecta a radiação na faixa do visivel ( 380 a $760 \mathrm{~nm}$ ). Foram realizadas 16 medições da luz difusa dentro da área útil de cada parcela, entre as linhas de plantio, com o sensor colocado na horizontal a, aproximadamente, $1 \mathrm{~m}$ do solo. Foi realizada uma medição no dia 06 de junho de 2000 , das 12:20 às 13:15 $\mathrm{h}$. 
Antes de iniciar e ao terminar cada bloco, foi medida a luz incidente total, fora do talhão experimental.

\subsection{Análise estatística dos dados}

Inicialmente, foi realizada uma análise exploratória dos dados, para verificar as pressuposições necessárias a cada análise, a necessidade de transformação dos dados ou de realização de análises não paramétricas.

Para analisar os dados referentes ao monitoramento nutricional e ciclagem de nutrientes, foram realizadas ANOVAs, de acordo com a análise de medidas repetidas, segundo Leal (1979). Quando detectada significância nas diferenças entre tratamentos, sem efeito significativo da interação, foi realizado o teste de Tukey, ao nivel de probabilidade de $5 \%$, para verificar as diferenças entre as médias. Para analisar os dados referentes ao sub-bosque, foram realizadas análises de regressão e dos intervalos de confiança, já que os tratamentos testados foram apenas aqueles representados por doses crescentes de biossólido (variável quantitativa com grau de dependência entre os níveis). 


\section{RESULTADOS e DISCUSSÃO}

\subsection{Avaliação do estado nutricional do eucalipto}

Os teores de todos os macronutrientes e maioria dos micronutrientes foram, significativamente, afetados pelos tratamentos (Tabela 4). Os teores de $\mathrm{N}, \mathrm{S}, \mathrm{Cu}$ e $\mathrm{Zn}$, foram alterados pelos tratamentos, sem interação com as épocas de coleta. Esses elementos apresentam a mesma tendência de variação em função dos tratamentos em todas as seis coletas, independente da época em que foram realizadas. 
Tabela 4. Resumo das ANOVAs entre tratamentos (1), épocas de coleta (2) e das interações entre os tratamentos e as épocas (1×2); para os teores de nutrientes foliares (Nut). Graus de liberdade: blocos (3), tratamentos (8), épocas de coleta (5), interação (40) e resíduo (159).

\begin{tabular}{|c|c|c|c|c|c|}
\hline Nut & Efeito & QME & QMR & $F$ & $p$ \\
\hline $\mathbf{N}$ & $\begin{array}{c}1 \\
2 \\
1 \times 2\end{array}$ & $\begin{array}{c}59,389 \\
584,069 \\
4,494\end{array}$ & 4,589 & $\begin{array}{c}12,97 \\
127,55 \\
0,98\end{array}$ & $\begin{array}{c}<0,001 \\
<0,001 \\
0,510\end{array}$ \\
\hline $\mathbf{P}$ & $\begin{array}{c}1 \\
2 \\
1 \times 2\end{array}$ & $\begin{array}{l}0,196 \\
1,045 \\
0,061\end{array}$ & 0,019 & $\begin{array}{c}10,45 \\
55,63 \\
3,27\end{array}$ & $\begin{array}{l}<0,001 \\
<0,001 \\
<0,001\end{array}$ \\
\hline K & $\begin{array}{c}1 \\
2 \\
1 \times 2\end{array}$ & $\begin{array}{c}6,996 \\
161,015 \\
2,232\end{array}$ & 0,520 & $\begin{array}{c}13,45 \\
309,67 \\
4,28\end{array}$ & $\begin{array}{l}<0,001 \\
<0,001 \\
<0,001\end{array}$ \\
\hline $\mathrm{Ca}$ & $\begin{array}{c}1 \\
2 \\
1 \times 2\end{array}$ & $\begin{array}{c}109,278 \\
574,185 \\
8,070\end{array}$ & 3,271 & $\begin{array}{c}33,82 \\
177,31 \\
2,50\end{array}$ & $\begin{array}{l}<0,001 \\
<0,001 \\
<0,001\end{array}$ \\
\hline $1 / \mathrm{Mg}^{*}$ & $\begin{array}{c}1 \\
2 \\
1 \times 2\end{array}$ & $\begin{array}{l}0,295 \\
0,519 \\
0,373\end{array}$ & 0,582 & $\begin{array}{c}10,08 \\
28,38 \\
2,55\end{array}$ & $\begin{array}{l}<0,001 \\
<0,001 \\
<0,001\end{array}$ \\
\hline s & $\begin{array}{c}1 \\
2 \\
1 \times 2\end{array}$ & $\begin{array}{c}0,356 \\
17,682 \\
0,058\end{array}$ & 0,046 & $\begin{array}{c}7,66 \\
381,00 \\
1,25\end{array}$ & $\begin{array}{c}<0,001 \\
<0,001 \\
0,172\end{array}$ \\
\hline $\mathrm{Fe}$ & $\begin{array}{c}1 \\
2 \\
1 \times 2\end{array}$ & $\begin{array}{c}794 \\
100141 \\
15,39\end{array}$ & 941 & $\begin{array}{c}0,84 \\
106,37 \\
1,63\end{array}$ & $\begin{array}{c}0,566 \\
<0,001 \\
0,018\end{array}$ \\
\hline $\mathbf{M n}$ & $\begin{array}{c}1 \\
2 \\
1 \times 2\end{array}$ & $\begin{array}{c}181480 \\
383890 \\
65225\end{array}$ & 9042 & $\begin{array}{c}20,07 \\
424,56 \\
7,21\end{array}$ & $\begin{array}{l}<0,001 \\
<0,001 \\
<0,001\end{array}$ \\
\hline $\mathbf{Z n}$ & $\begin{array}{c}1 \\
2 \\
1 \times 2\end{array}$ & $\begin{array}{c}249,37 \\
1019,53 \\
63,81\end{array}$ & 63,08 & $\begin{array}{c}3,41 \\
14,14 \\
0,89\end{array}$ & $\begin{array}{c}0,001 \\
<0,001 \\
0,666\end{array}$ \\
\hline $\mathrm{Na}$ & $\begin{array}{c}1 \\
2 \\
1 \times 2\end{array}$ & $\begin{array}{c}88589 \\
460620 \\
83202\end{array}$ & 11744 & $\begin{array}{c}0,75 \\
39,22 \\
0,71\end{array}$ & $\begin{array}{c}0,643 \\
<0,001 \\
0,899\end{array}$ \\
\hline B & $\begin{array}{c}1 \\
2 \\
1 \times 2\end{array}$ & $\begin{array}{c}70,13 \\
1324,12 \\
124,94\end{array}$ & 32,81 & $\begin{array}{c}0,16 \\
40,36 \\
3,81\end{array}$ & $\begin{array}{l}0,035 \\
<0,001 \\
<0,001\end{array}$ \\
\hline
\end{tabular}

*transformação realizada para o teor de magnésio, para atingir homocedasticidade 
Pode-se observar que há um efeito significativo da época de coleta e dos tratamentos aplicados na área experimental sobre o teor foliar de $\mathrm{N}$ (Tabela 4). Analisando a influência dos tratamentos sobre o teor foliar de $N$, observa-se uma nítida separação, estatisticamente significativa, em dois grupos. Um, composto pelos tratamentos testemunha (tt), adubação mineral (ad) e a menor dose de biossólido complementado com $\mathrm{K}(5+\mathrm{K})$, que apresenta concentrações de $\mathrm{N}$ inferiores ao outro grupo dos demais tratamentos (Figura 5).

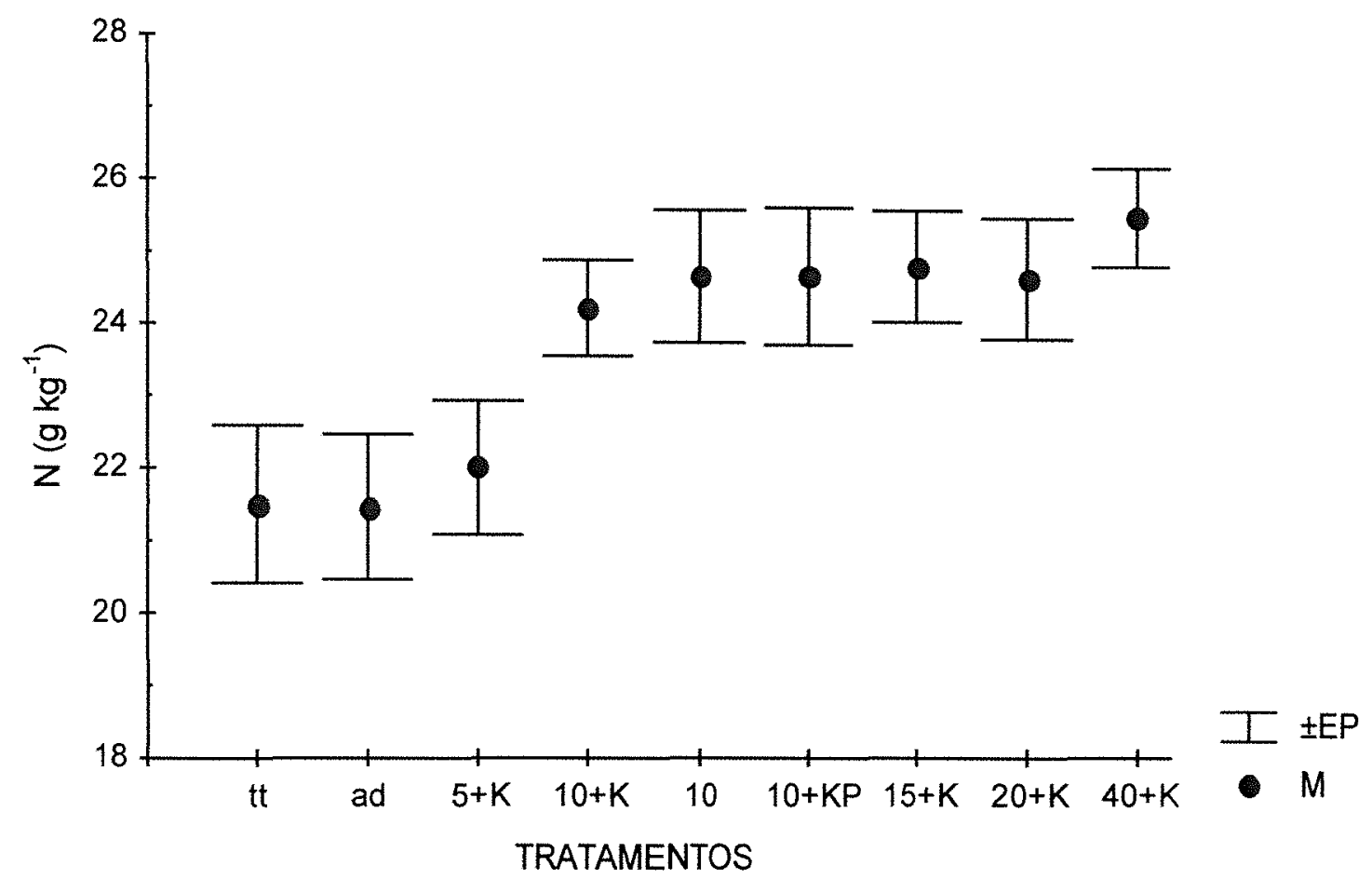

Figura 5. Valores médios (M) e dos erros padrões das médias (EP), de teores de $\mathrm{N}$ foliar em eucalipto, em folhas coletadas durante seis épocas (de 2 a 16 meses após aplicação do biossólido), para cada tratamento testado $(\mathrm{N}=24)$.

Foi observado maior teor de $\mathrm{N}$ foliar nas plantas dos tratamentos onde $\mathrm{O}$ biossólido foi aplicado na dose de $10 \mathrm{t} \mathrm{ha}^{-1}$ e acima (teor médio $=24,7 \mathrm{~g} \mathrm{~kg}^{-1}$ ). $\mathrm{O}$ aumento observado ocorreu durante todo o período, desde 2 a 16 meses após aplicação do biossólido, indicando que o desenvolvimento em idade e o crescimento do povoamento, não determinaram alterações no padrão de maior acúmulo de $\mathrm{N}$ nas folhas das árvores que receberam o resíduo. $\mathrm{O}$ biossólido 
mantém niveis maiores do que 0 adequado, $13-18 \mathrm{~g} \mathrm{~kg}^{-1}$ segundo o critério adotado por Gonçalves et al. (1996), mesmo quando o crescimento é mais acentuado.

A provável liberação lenta e constante dos nutrientes contidos no biossólido pode ser uma grande vantagem quando comparado com a adubação mineral. Como o material foi aplicado em superfície, a decomposição só acontece na interface de contato do resíduo com o solo, de maneira muito lenta. Ainda hoje, é possível observar com nitidez, restos do biossólido aplicado na área.

As plantas testemunhas, assim como as que receberam adubação mineral (ad) e $5 \mathrm{t} \mathrm{ha}^{-1}$ de biossólido $(5+\mathrm{K})$, apresentaram os teores mais baixos de $\mathrm{N}$ (teor médio $=21,4 \mathrm{~g} \mathrm{~kg}^{-1}$ ). Mesmo esses teores estão acima dos considerados adequados, na matéria seca de folhas de plantas adultas de Eucalyptus. Os restos culturais deixados durante o sistema de cultivo mínimo, foram suficientes para liberar $\mathrm{N}$ para as plantas testemunhas manterem um nivel adequado do nutriente. Essas plantas sempre cresceram menos do que as dos outros tratamentos (Figuras 3 e 4), o que determina um efeito de concentração quando há nutriente disponível. $O$ adubo mineral, prontamente solúvel e rapidamente disponibilizado para as plantas, foi suficiente para sustentar o rápido crescimento inicial das plantas cultivadas no tratamento "ad" e o maior incremento de biomassa, porém mantendo a concentração de $\mathrm{N}$ nas folhas relativamente baixa quando comparada aos tratamentos que receberam doses maiores de biossólido.

A maior absorção de $\mathrm{N}$, nos tratamentos que receberam biossólido, foi considerada como possível causa para explicar a ausência de movimentação de nitratos no perfil do solo (Andrade, 1999). Este autor desenvolveu seus trabalhos na mesma área experimental, integrado ao sub-projeto 5 do programa SABESP/IPEF/ESALQ.

Zabowski e Henry (1994) também encontraram que o biossólido propiciou o aumento de $\mathrm{N}$ nas folhas das plantas, em uma floresta madura de 
Pinus ponderosa no estado Washington (EUA). Eles verificaram que o efeito durou até 5 anos após aplicação.

McDonald et al. (1993), trabalhando com Thuja plicata, em Vancouver no Canadá, também detectaram aumentos estatisticamente significativos da concentração foliar de $\mathrm{N}$ em folhas das árvores tratadas com biossólido $(16,0 \mathrm{~g}$ $\left.\mathrm{kg}^{-1}\right)$, um ano após aplicação, em comparação com as árvores testemunhas $\left(10,1 \mathrm{~g} \mathrm{~kg}^{-1}\right)$. Nesse experimento foram aplicadas $69 \mathrm{t} \mathrm{ha}^{-1}$ de biossólido, cujo teor de $\mathrm{N}$ era de $30 \mathrm{~g} \mathrm{~kg}^{-1}$. Esses autores também encontraram aumentos significativos, em ambas as coletas, para o elemento $P$.

Observando a Tabela 4, percebemos que o teor foliar de $P$ foi afetado, significativamente, pela época de coleta e pelos tratamentos aplicados na área experimental, bem como pela interação entre esses fatores. Essa interação significativa mostra que o efeito dos tratamento não é o mesmo em todas as épocas, sendo necessária a análise de cada época separadamente.

O P é um nutriente chave para o desenvolvimento do eucalipto, principalmente, na fase inicial, quando as plantas respondem prontamente à sua absorção. Ele é um elemento que pode estar sob várias formas no solo, afetando sua dinâmica de extração pelas plantas.

$O$ teor adequado de $P$ em eucalipto, segundo Gonçalves et al. (1996), varia em uma faixa de 0,9-1,3 $\mathrm{g} \mathrm{kg}^{-1}$. Já, Wadt e Novais (1997), citam como nível crítico para esse elemento o valor de $1,6 \mathrm{~g} \mathrm{~kg}^{-1}$.

Pode-se observar a seguir que, mesmo considerando todas as épocas de coleta e todos os tratamentos, não houve acúmulo de $P$ e que seus teores, de maneira geral, encontram-se dentro ou próximos aos valores apresentados como adequados.

Pode-se observar também que ocorrem várias interações para o teor de $P$, entre os tratamentos e as épocas de coleta (Figura 6). Há uma diminuição nos teores de $P$, em todos os tratamentos, na quinta e sexta coletas, em relação à quarta. Esse fato pode estar associado à diminuição da precipitação pluviométrica. A difusão do $P$ é dificultada em condições de baixa umidade no 
solo. No período de 07 a 11/99 foram registrados baixos indices pluviométricos (Figura 2).

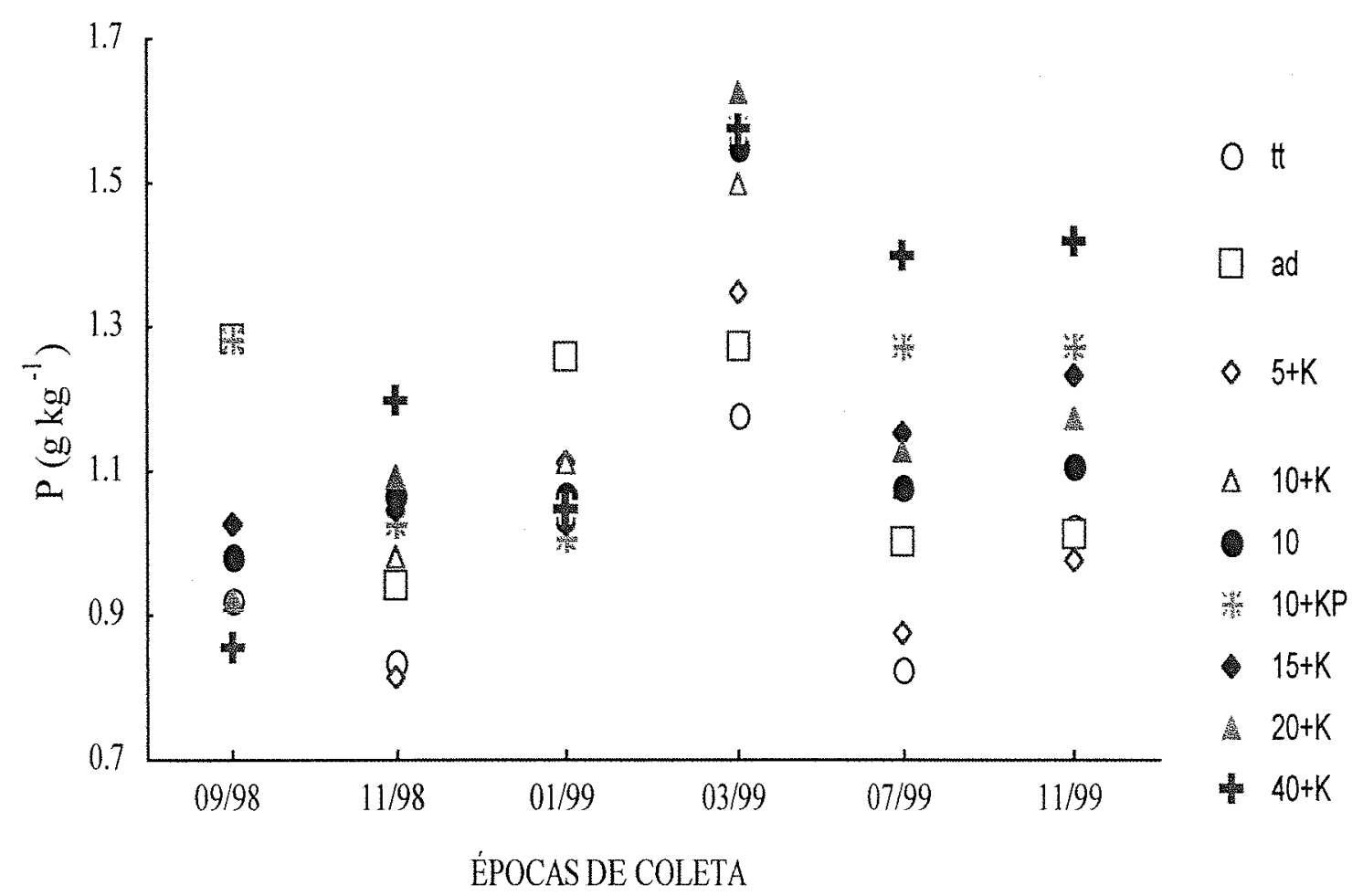

Figura 6. Teores médios $(N=4)$ de $P$ nas folhas de eucalipto, em cada tratamento, para cada época de coleta diferente.

Após um ano da aplicação do biossólido, na quinta (07/99) e sexta (11/99) coletas, o efeito dos tratamentos torna-se mais evidente, destacando-se aquele que recebeu a maior dose de biossólido $(40+K)$. Na quinta coleta, por exemplo, as médias \pm erros padrões dos teores de $P$ nas plantas dos tratamentos "40+K" $\left(1,4 \mathrm{~g} \mathrm{~kg}^{-1} \pm 0,04\right)$ e "10+KP" $\left(1,3 \mathrm{~g} \mathrm{~kg}^{-1} \pm 0,05\right)$ são maiores do que as encontradas no "tt" $\left(0,8 \mathrm{~g} \mathrm{~kg}^{-1} \pm 0,05\right)$, no " $5+\mathrm{K}^{\prime}\left(0,9 \mathrm{~g} \mathrm{~kg}^{-1} \pm 0,07\right)$ e no "ad" $\left(1,0 \mathrm{~g} \mathrm{~kg}^{-1} \pm 0,04\right)$. Esse resultado coincide com os encontrados por Vaz (2000), que trabalhou na mesma área experimental. Ele constatou que o teor de 
$P$ no solo não foi alterado 6 meses após a aplicação dos tratamentos (01/99). No entanto, 13 meses após (08/99) a aplicação, foi constatado considerável aumento no teor de $P$, principalmente no tratamento que recebeu $40 \mathrm{t} \mathrm{ha}^{-1}$ de biossólido ("40+K"). Segundo Lindo et al. (1995), que estudou o $P$ orgânico residual em solo tratado com elevadas doses de biossólido, a fração de $P$ predominante (65 a 84\%) é aquela moderadamente lábil. Segundo Bekunda (1991), a aplicação de lodo de esgoto primário não digerido não foi uma fonte imediata de $\mathrm{P}$ lábil no solo, e mostrou tendência de efeitos a longo prazo.

A resposta após um ano de aplicação, pode indicar que o $P$ contido no biossólido não é prontamente lábil e está sendo liberado lentamente. Outra hipótese é que, como o biossólido foi aplicado entre as linhas de plantio e o P é um elemento que se movimenta pouco no solo, no início do desenvolvimento as mudas ainda não possuiam um sistema radicular desenvolvido o bastante para chegar até onde o P estava sendo liberado.

Aos dois meses após aplicação (09/98), pode-se observar nitidamente na Figura 6, os picos proporcionados pelo $P$ mineral, nos tratamentos " $\mathrm{ad}^{\text {" }}(1,3 \mathrm{~g}$ $\left.\mathrm{kg}^{-1} \pm 0,03\right)$ e "10 $+\mathrm{KP}$ " $\left(1,3 \mathrm{~g} \mathrm{~kg}^{-1} \pm 0,00\right)$, valores esses estatisticamente maiores do que os encontrados no tratamento "40+K" $\left(0,8 \mathrm{~g} \mathrm{~kg}^{-1} \pm 0,10\right)$. O P do adubo mineral é prontamente disponivel e foi rapidamente extraído pelas plantas.

Os dados referentes ao $\mathrm{K}$, não são apresentados, pois os resultados das análises não foram considerados confiáveis para sua interpretação, devido a problemas ocorridos durante a condução do experimento.

O Ca foi o nutriente que apresentou o padrão mais nítido de incremento da concentração foliar em função das doses crescentes de biossólido (Figura 7). Nessa figura observa-se também, que os tratamentos testemunha ( $t \mathrm{t}$ ), adubação mineral (ad) e a menor dose de biossólido complementado com $\mathrm{K}$ $(5+K)$, sempre apresentaram concentrações de $\mathrm{Ca}$ inferiores aos demais tratamentos. As diferenças entre tratamentos torna-se mais acentuada a partir da terceira coleta, 6 meses após aplicação do biossólido. 


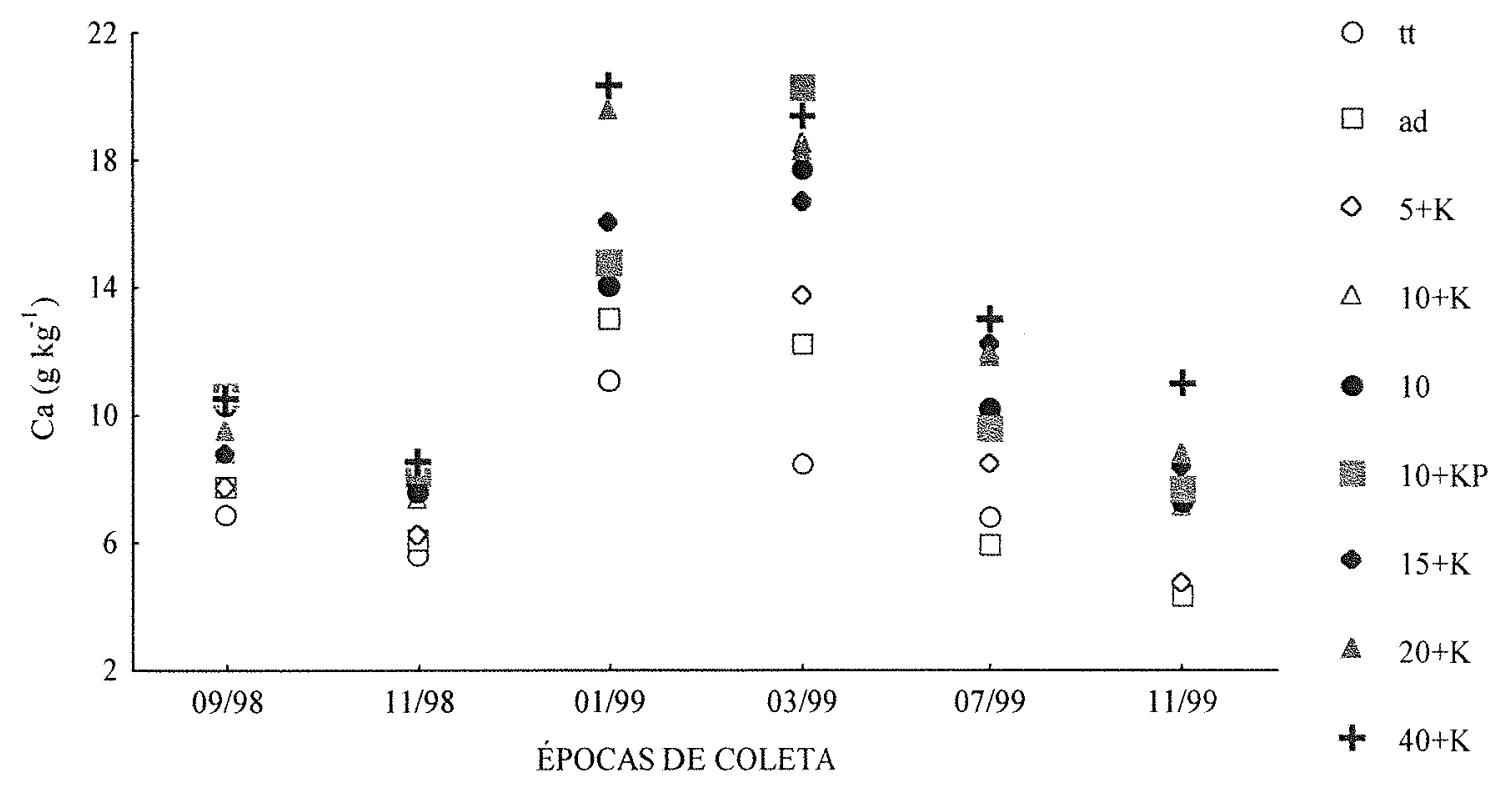

Figura 7. Teores médios $(\mathrm{N}=4)$ de $\mathrm{Ca}$ foliar em cada tratamento, dentro das diferentes épocas de coleta.

As plantas do tratamento onde foi aplicada a maior dose de biossólido $(40+\mathrm{K})$, apresentaram os valores médios mais elevados de $\mathrm{Ca}$ foliar. Esse tratamento se isolou dos demais na última coleta. Ele apresentou uma menor redução em função da coleta anterior do que os outros tratamentos, apresentando concentração \pm erro padrão $(11,0 \pm 1,00)$, significativamente maior do que os tratamentos "tt" $(4,3 \pm 0,20)$, "ad" $(4,3 \pm 0,40)$, "5+K" $(4,7 \pm$ $0,39)$, "10+K" (7,1 $\pm 0,63), " 10 "(7,3 \pm 0,60)$ e "10 + KP" $(7,7 \pm 0,55)$.

Pode-se observar na Figura 7 que a partir da quarta coleta houve uma redução das concentrações foliares de $\mathrm{Ca}$, em todos os tratamentos. Esse fato pode estar associado à maior produção de madeira e casca pelas árvores, demandando uma maior quantidade de Ca no lenho, em detrimento do teor de $\mathrm{Ca}$ nas folhas. A redução foi mais acentuada no tratamento "10+KP", justamente aquele que apresentou o maior crescimento (Figura 4). 
A grande quantidade de $\mathrm{Ca}$ existente no biossólido $\left(86 \mathrm{~g} \mathrm{~kg}^{-1}\right)$, resultou em concentrações foliares duas a três vezes superiores nas plantas dos tratamentos que receberam doses elevadas em relação ao tratamento testemunha, principalmente a partir da terceira coleta (01/99). Na terceira coleta o valor médio do tratamento "40+K" foi o dobro do nível crítico de $10 \mathrm{~g} \mathrm{~kg}^{-1}$ citado por Wadt e Novais (1997). Apesar desses teores elevados de Ca, não foram detectados problemas de excesso e as plantas vêm se desenvolvendo normalmente. Segundo Bellote e Silva (2000), o crescimento das árvores de Eucalyptus não guarda relação com teores de Ca nas folhas.

O excesso de Ca pode estar causando a diminuição da concentração do elemento $\mathrm{Mg}$ em plantas que receberam biossólido, conforme pode ser observado na Figura 8.

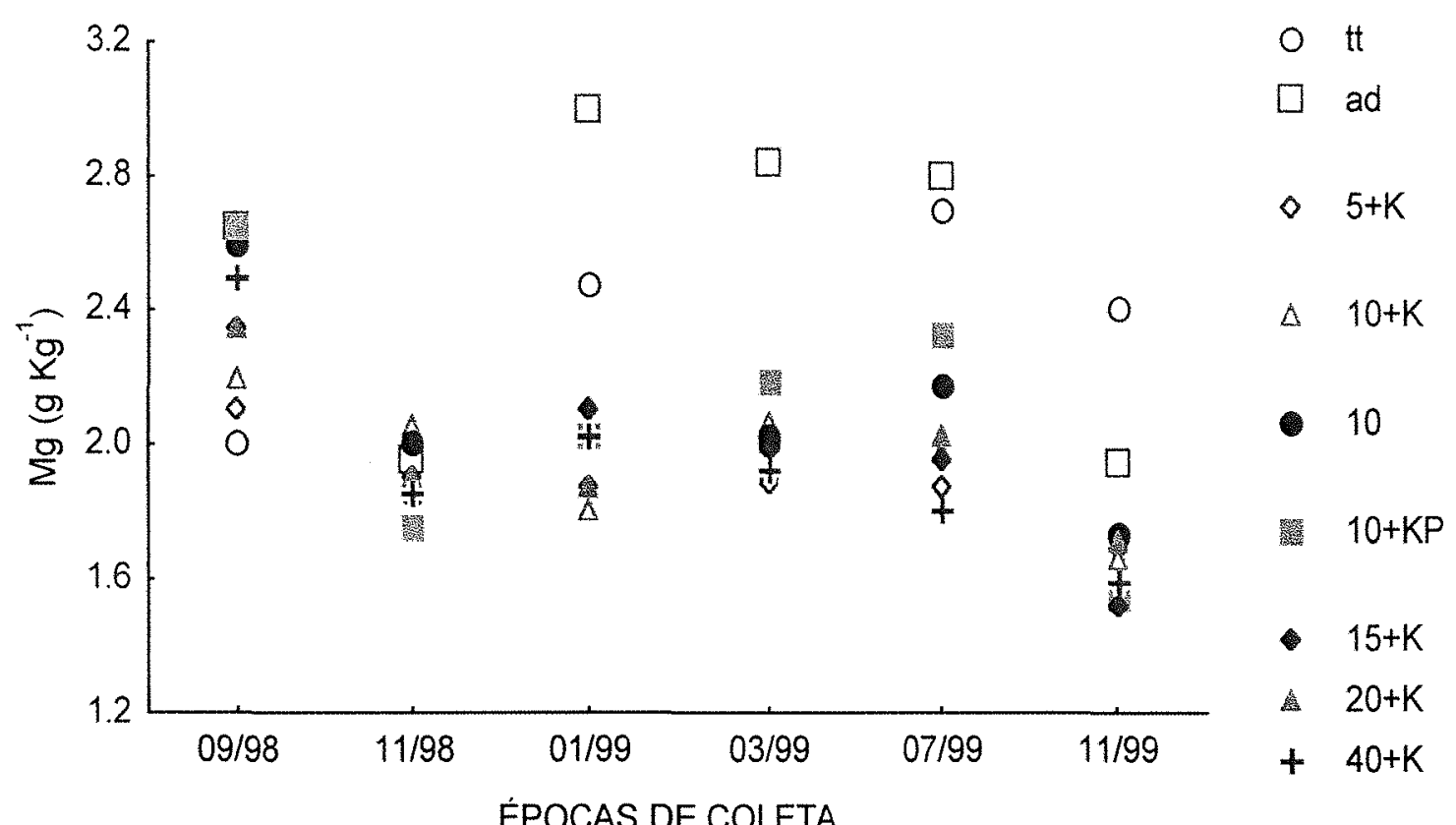

Figura 8. Teores médios $(\mathrm{N}=4)$ de $\mathrm{Mg}$ foliar em cada tratamento, dentro das diferentes épocas de coleta. 
As plantas que receberam adubação mineral e as plantas testemunhas, a partir de 6 meses após aplicação do biossólido, mantém-se com uma concentração mais elevada de $\mathrm{Mg}$ do que as plantas que receberam biossólido.

$\mathrm{Na}$ quarta coleta o teor médio ! erro padrão do tratamento "ad" $\left(2,8 \mathrm{~g} \mathrm{~kg}^{-1}\right.$ $\pm 0,16$ ), foi significativamente maior do que todos os outros tratamentos, inclusive o "10+KP" com teor de $2,2 \mathrm{~g} \mathrm{~kg}^{-1} \pm 0,09$. Isso indica que o excesso de Ca do biossólido está induzindo deficiência desse elemento, como pode ser constatado pela relação $\mathrm{Ca} / \mathrm{Mg}$ mostrada na Tabela 5 . No caso da cultura de eucalipto, esse fato não representa um grande risco. Novais e Barros (1990) comentam que a baixa demanda de Mg para o Eucalipto, faz com que a relação $\mathrm{Ca} / \mathrm{Mg}$ trocáveis ideal para seu crescimento ótimo seja bastante larga.

Segundo Gonçalves et al. (1996), a faixa crítica para o Mg varia de 3,5$5,0 \mathrm{~g} \mathrm{~kg}^{-1}$. Segundo Wadt e Novais (1997), o nível crítico é de $3 \mathrm{~g} \mathrm{~kg}^{-1}$. Apenas as plantas que receberam calcário dolomítico durante adubação mineral, conseguem atingir, em algumas épocas de coleta, esse nivel critico.

Tabela 5. Valores médios de seis épocas de coleta $(\mathrm{N}=24)$, para a relação entre os teores de $\mathrm{Ca}$ e $\mathrm{Mg}$ nas folhas das plantas cultivadas nos diversos tratamentos (TT). Entre parênteses são apresentados os valores do erro padrão da média.

\begin{tabular}{lccccccccc}
\hline TT & $\mathrm{tt}$ & $\mathrm{ad}$ & $5+\mathrm{k}$ & $10+\mathrm{K}$ & 10 & $10+\mathrm{KP}$ & $15+\mathrm{K}$ & $20+\mathrm{K}$ & $40+\mathrm{K}$ \\
$\mathrm{Ca} / \mathrm{Mg}$ & 3,3 & 3,2 & 4,9 & 5,9 & 5,4 & 5,8 & 5,9 & 6,6 & 7,2 \\
& $(0,5)$ & $(0,5)$ & $(1,0)$ & $(1,1)$ & $(0,9)$ & $(1,1)$ & $(0,8)$ & $(1,4)$ & $(1,3)$ \\
\hline
\end{tabular}

Em uma área dos EUA, cultivada com Abies grandis e Pseudotsuga menziesii, oito anos após a aplicação de $300 \mathrm{tha}^{-1}$ (peso seco) de lodo de esgoto, houve sintomas de deficiência de $\mathrm{Mg}$. Analisando o tecido foliar das plantas da área testemunha, foi encontrado um teor de $\mathrm{Mg}$ de $0,93 \mathrm{~g} \mathrm{~kg}^{-1}$, enquanto na área tratada com lodo $0,25 \mathrm{~g} \mathrm{~kg}^{-1}$. Isso indica que a aplicação do lodo pode ter sido a causa de deficiência de $\mathrm{Mg}$, provavelmente, devido à 
competição por sítios de absorção com outros cátions existentes no lodo em teores mais elevados que o Mg (Harrison et al., 1994).

A análise de variância para o teor de $S$ mostra que os efeitos principais foram significativos e que não houve significância para a interação (Tabela 4). Como não houve interação significativa, o aumento do teor de $S$ observado nos tratamentos que receberam as maiores doses de biossólido, ocorre independente da época de coleta. Esse elemento está diretamente ligado à dinâmica de decomposição de material orgânico, sendo um dos principais nutrientes cuja origem orgânica é a principal fonte do elemento no solo. No tratamento "ad", não foi colocada nenhuma fonte de $S$ mineral, o que refletiu nas menores concentrações desse elemento nas plantas que receberam adubação química, quando comparado com as plantas que receberam doses maiores ou iguais a $10 \mathrm{tha}^{-1}$ (Figura 9 ).

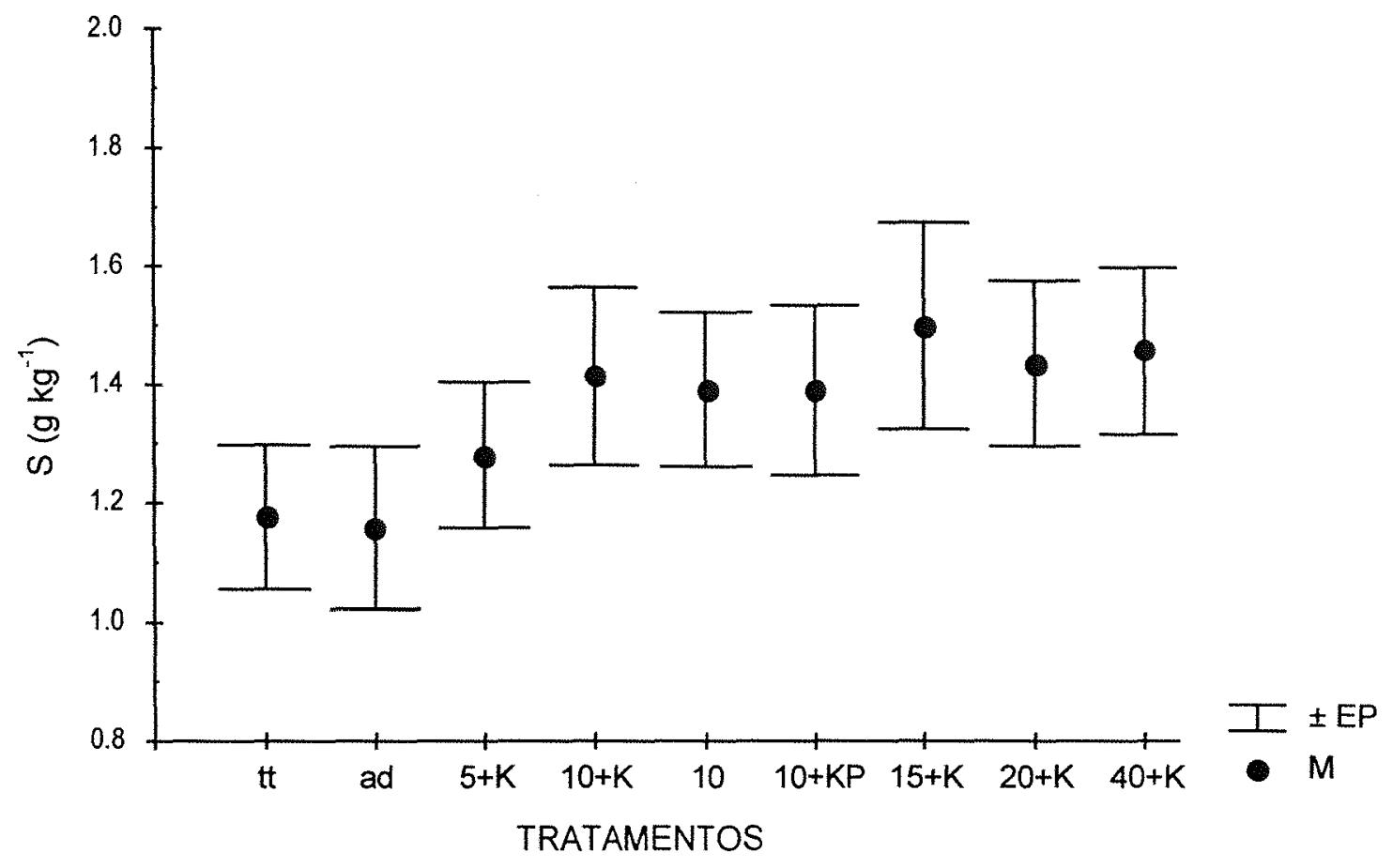

Figura 9. Valores médios (M) e dos erros padrões (EP) de teores de $S$ foliar em eucalipto. Médias de seis épocas de coleta $(N=24)$, para cada tratamento testado. 
Em Vancouver (Canadá), árvores tratadas com fertilizantes inorgânicos sofreram deficiência de $S$, enquanto áreas tratadas com biossólido não apresentaram essa deficiência (Weetman et al., 1993). Vaz (2000), trabalhando na mesma área experimental, observou significativos aumentos do $\mathrm{S}_{-} \mathrm{SO}_{4}{ }^{-}$no solo com a aplicação de biossólido.

A análise de variância para o elemento Fe mostra que os tratamentos aplicados na área não afetaram, significativamente, o teor desse nutriente nas folhas do eucalipto (Tabela 4). O Fe, apesar de extremamente concentrado no biossólido, de maneira geral não está se concentrando nas copas das plantas de eucaliptos que receberam o resíduo, tanto que não houve efeito significativo para tratamentos. Considerando todas as épocas e tratamentos, o teor de $\mathrm{Fe}$ nas folhas do terço superior da copa do eucalipto, não chegou a $300 \mathrm{mg} \mathrm{kg}^{-1}$. Esse elemento parece ser absorvido preferencialmente pela vegetação do subbosque, que apresenta teores sempre acima de $400 \mathrm{mg} \mathrm{kg}^{-1}$, atingindo valores maiores que $1000 \mathrm{mg} \mathrm{kg}^{-1}$.

A análise de variância para o teor de Mn mostra que todos os efeitos testados foram significativos (Tabela 4).

Pode-se observar na figura abaixo que o teor de $\mathrm{Mn}$ no tratamento testemunha (tt), a partir da terceira coleta (01/99), destaca-se de todos os outros tratamentos (Figura 10). Na quarta coleta, o teor médio \pm erro padrão de Mn no tratamento "tt" (1406 mg kg-1 \pm 138$)$, é, significativamente maior do que em todos os outros tratamentos, inclusive o "ad" (969 mg kg-1 \pm 73 ). 


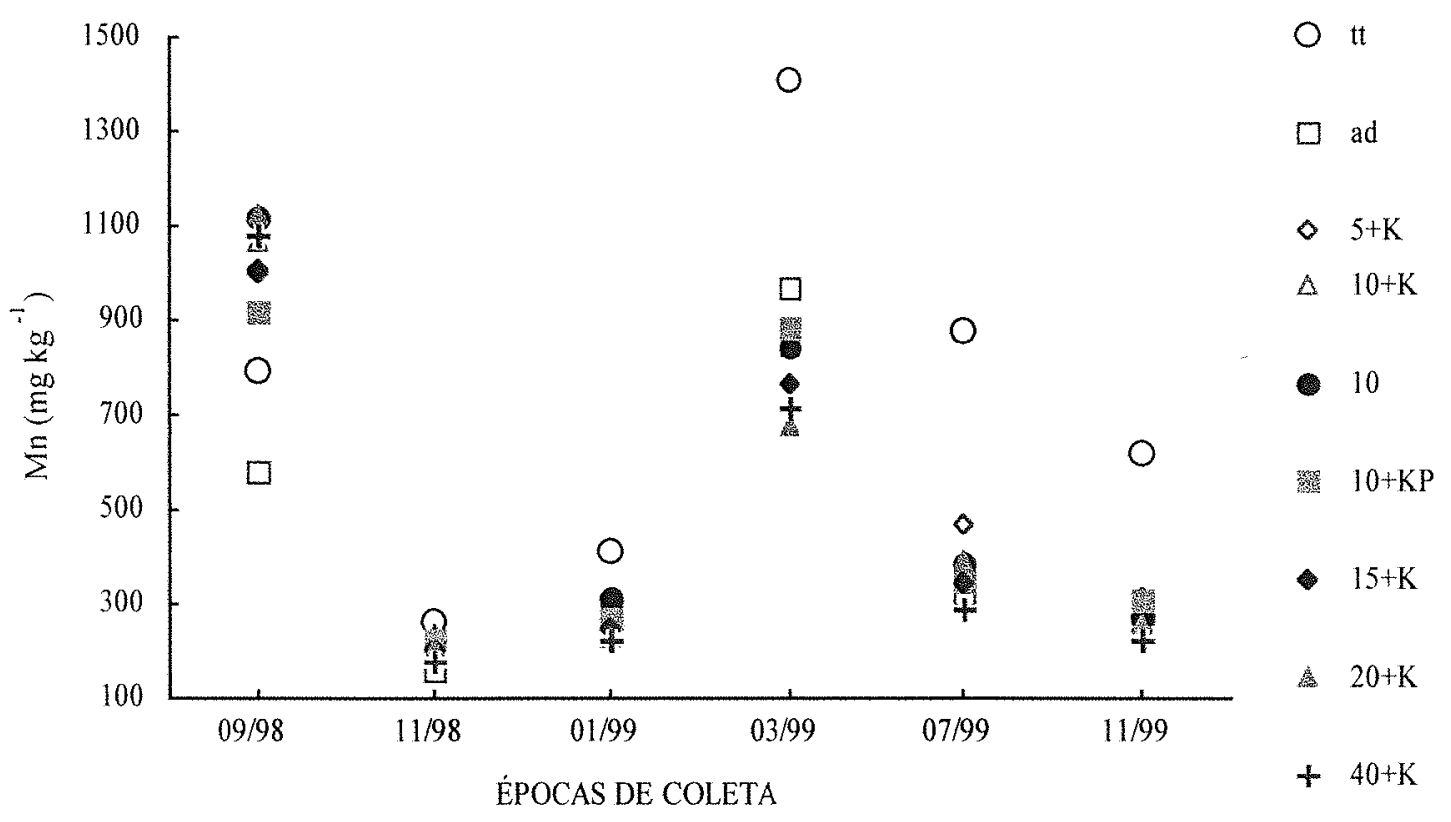

Figura 10. Teores médios de $M n$ foliar em cada tratamento $(N=4)$, dentro das épocas de coleta.

Os menores valores de $\mathrm{Mn}$ na segunda coleta, podem estar associados à diminuição da umidade do solo, já que em novembro de 1998 choveu apenas 6 $\mathrm{mm}$ (Figura 2). A diminuição do teor de $\mathrm{Mn}$ com o aumento da dose de biossólido, pode ser considerada benéfica para o eucalipto. O nível crítico desse elemento, segundo Wadt e Novais (1997), é de $675 \mathrm{mg} \mathrm{kg}^{-1}$, sendo que abaixo desse valor não é detectada deficiência, podendo, no entanto, ocorrer problema de excesso e toxicidade para valores maiores.

A diminuição dos teores de $\mathrm{Mn}$ com o aumento das doses de biossólido $\left(\mathrm{pH}=10,6\right.$ e $\left.\mathrm{Ca}=86 \mathrm{~g} \mathrm{~kg}^{-1}\right)$, pode estar associada ao aumento do $\mathrm{pH}$ e do material orgânico do solo ou à competição por sítios de absorção com outros cátions mais concentrados, particularmente, o Ca. Como o teor de Mn também diminuiu nas plantas que receberam adubação mineral, provavelmente, esse efeito pode ser atribuído ao aumento de $\mathrm{pH}$, já que no tratamento "ad" não 
houve adição de material orgânico e nem de $\mathrm{Ca}$ em excesso. Em trabalho de Tsadilas et al. (1995), Fe e Mn no solo, extraídos por DTPA, foram reduzidos com aplicação de biossólido, mostrando uma forte correlação negativa com o $\mathrm{pH}$.

A Figura 11 mostra que, realmente, não houve competição entre $\mathrm{Ca}$ e $\mathrm{Mn}$ durante a absorção, já que foi encontrada correlação positiva entre os teores desses nutrientes dentro das plantas.

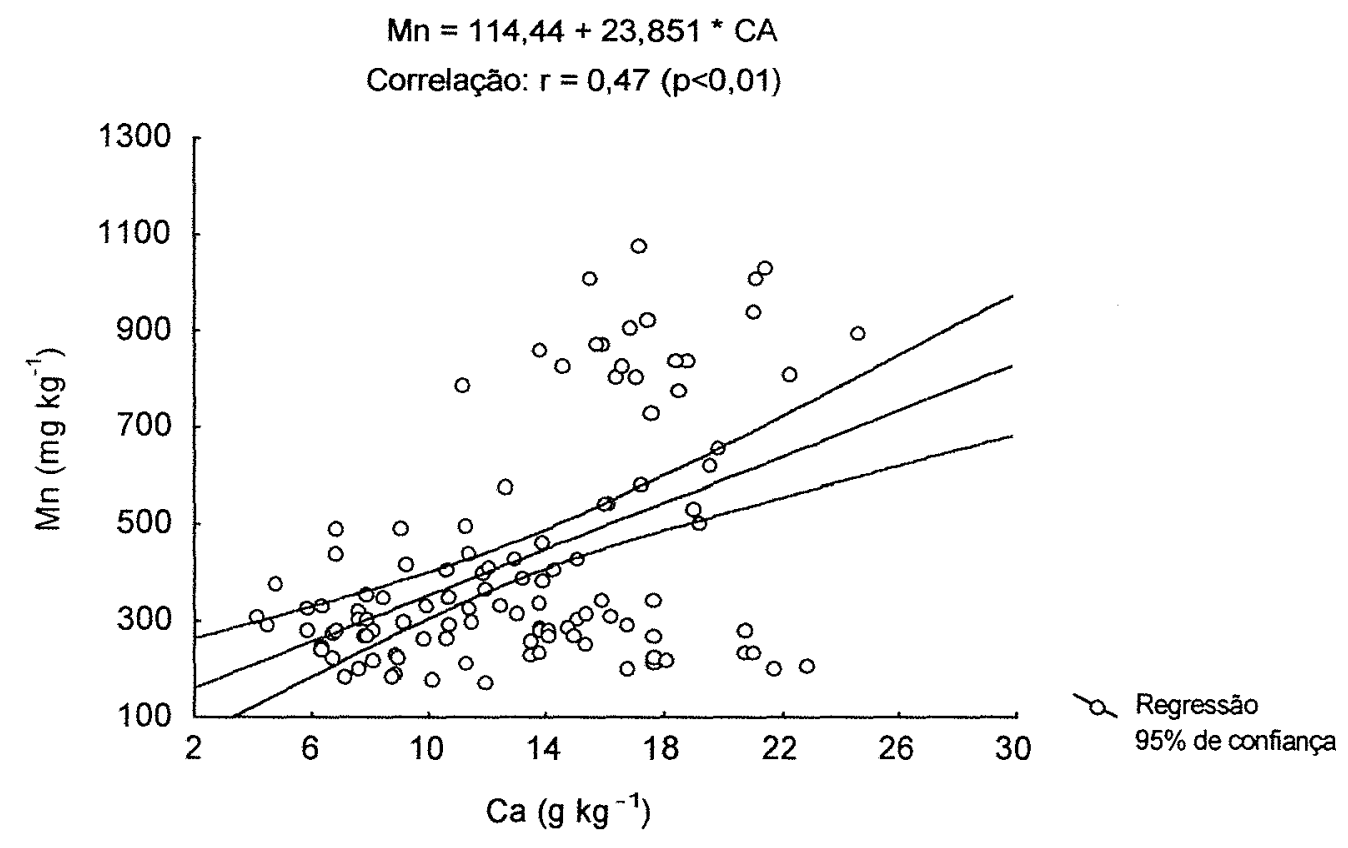

Figura 11. Correlação entre os teores de $\mathrm{Mn}$ e Ca foliares. Dados de todos os tratamentos e épocas de coleta $(\mathrm{N}=144)$.

Em observação complementar, foram analisadas folhas de duas plantas de eucalipto que cresciam diretamente sobre o monte de biossólido armazenado no campo, próximo à área experimental. Estas análises mostraram teores extremamente baixos de $\mathrm{Mn}$ (49 e $29 \mathrm{mg} \mathrm{kg}^{-1}$ ). Como essas plantas encontravam-se pouco desenvolvidas não há possibilidade de ter ocorrido 0 efeito diluição. Isso mostra que a diminuição no teor de $\mathrm{Mn}$ nas plantas dos 
outros tratamentos em relação ao testemunha, não ocorreu devido ao maior desenvolvimento das plantas e consequente diluição do elemento.

O tratamento que recebeu apenas dez toneladas de biossólido, sem complementação mineral, apresentou os valores mais elevados para os teores foliares de Zn (Figura 12).

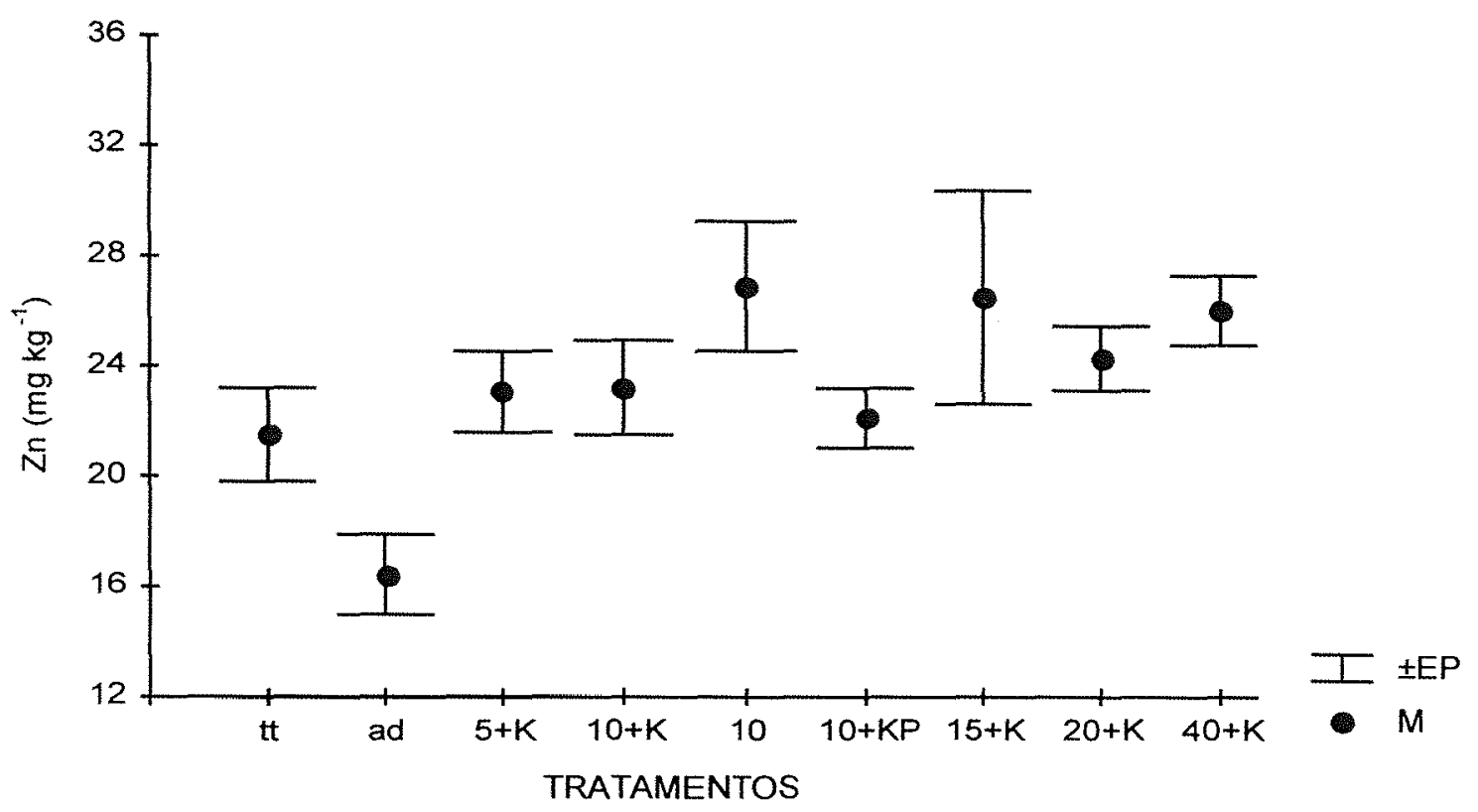

Figura 12. Teores médios (M) e dos erros padrões (EP) das médias de $\mathrm{Zn}$ nas folhas de eucalipto, para cada tratamento testado, considerando todas as épocas de coleta $(\mathrm{N}=24)$.

Uma reconhecida interação negativa do $\mathrm{Zn}$ com o $\mathrm{P}$ devido à inibição não competitiva (Malavolta et al. 1997), pode explicar a diminuição no teor de Zn nas plantas do tratamento "ad" onde $P$ mineral foi aplicado, em relação ao tratamento "10" e os que receberam doses maiores do que $10 \mathrm{t} \mathrm{ha}^{-1}(15+\mathrm{K}$, $20+K$ e $40+K)$. No tratamento "10+KP", que também recebeu $P$ mineral na base, essa diminuição não foi tão acentuada e esse tratamento não difere dos que receberam doses maiores de biossólido. Esse fato pode estar associado à liberação de $\mathrm{Zn}$ do biossólido. 


\subsection{Ciclagem de nutrientes via folhedo}

O ciclo biogeoquímico contempla a árvore como um dos principais componentes da reciclagem de nutrientes, através da deposição da serapilheira. Nesse estudo, o material vegetal que está sendo deposto pelas árvores, que ainda se encontram em fase inicial de desenvolvimento, é constituido quase que totalmente por folhas. Outros componentes da serapilheira como frutos, flores, casca e galhos grossos, ainda não caíram nos coletores. Assim optou-se por utilizar o termo folhedo ao invés de serapilheira.

Vale ressaltar que existe um aspecto dinâmico na análise do folhedo e da ciclagem dos nutrientes, pois à medida que ele vai sendo produzido e acumulado, também vai sendo decomposto e incorporado ao solo.

Nesta pesquisa o estudo da ciclagem começou quando as plantas encontravam-se em uma fase juvenil de desenvolvimento e apresentavam 17 meses de idade e fechando suas copas. Com o amadurecimento do povoamento, os resultados aqui apresentados e a dinâmica da ciclagem deverão ser alterados.

\subsubsection{Deposição de folhedo}

Em um ano de coleta do folhedo produzido, foram registrados valores superiores a $4000 \mathrm{~kg} \mathrm{ha-1}$ de biomassa seca. Essa é uma quantidade substancial de matéria orgânica e nutrientes que é reciclada dentro do ecossistema, contribuindo para a sustentabilidade do mesmo. O ecossistema florestal tem a capacidade de enriquecer, continuamente, o solo com matéria orgânica, através da fixação de elevadas quantidades de $\mathrm{CO}_{2}$ atmosférico em sua biomassa, que vai se depositando na área. As plantas do tratamento que recebeu a maior dose de biossólido depositaram a maior quantidade de biomassa foliar (Figura 13). 


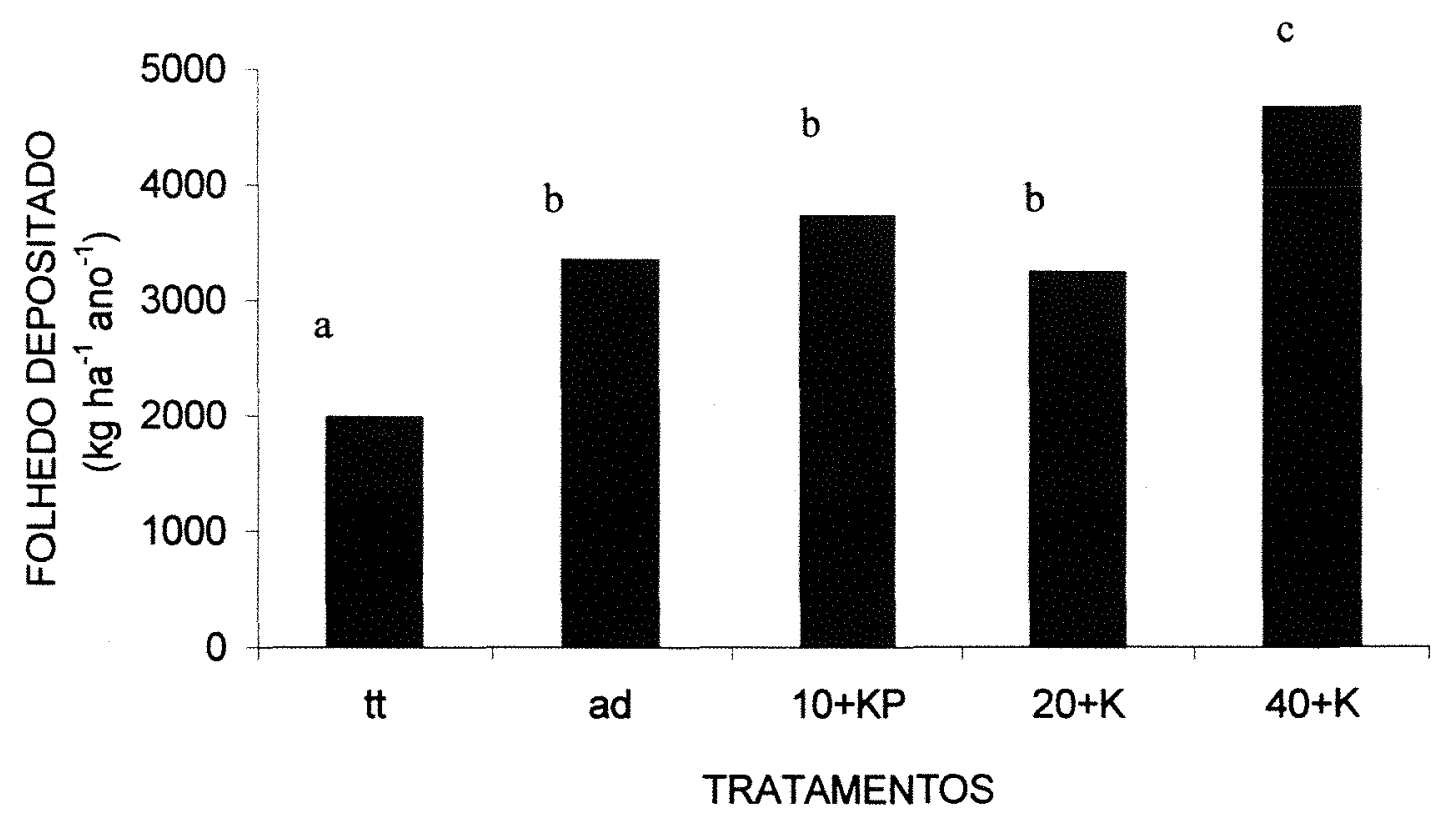

Figura 13. Média $(\mathrm{N}=4)$ da deposição anual de folhedo de eucalipto, durante o período de setembro de 1999 a agosto de 2000. Colunas sob letras iguais mostram que as médias não diferem entre si, pelo teste de Tukey a $5 \%$ de probabilidade.

A produção média \pm desvio padrão das plantas testemunhas foi de 1976 $\pm 931 \mathrm{~kg} \mathrm{ha}^{-1}$ ano $^{-1}$ de folhedo, valor este, inferior a todos os tratamentos testados. As plantas que receberam $40 \mathrm{t} \mathrm{ha}^{-1}$ de biossólido produziram $4662 \pm$ $761 \mathrm{~kg} \mathrm{ha}^{-1}$ ano $^{-1}$. As plantas que receberam adubação mineral produziram $3338 \pm 318 \mathrm{~kg} \mathrm{ha}^{-1} \mathrm{ano}^{-1}$. Schumacher (1992), trabalhando durante o período de 1989 a 1991, encontrou valor médio do folhedo produzido em 2 anos, de 3138 $\mathrm{kg} \mathrm{ha}^{-1}$ ano $^{-1}$ para Eucalyptus grandis com 7 anos de idade, valor este parecido com o encontrado neste trabalho para as plantas que receberam adubação mineral. Carpanezi (1980), observou deposição de $4687 \mathrm{~kg} \mathrm{ha}^{-1} \mathrm{ano}^{-1}$ de folhas de Eucalyptus grandis aos 5 anos de idade.

Com a aplicação de biossólido, a área do tratamento " $40+K$ " recebeu $6880 \mathrm{~kg}$ de carbono orgânico por hectare, enquanto que a área testemunha não recebeu nada. Em apenas um ano de deposição de folhedo, as plantas do tratamento " $40+K$ " depositaram $2686 \mathrm{~kg}$ de biomassa a mais do que as testemunhas. Considerando que $50 \%$ desse material é constituído por carbono 
orgânico, a área que recebeu $40 \mathrm{t} \mathrm{ha}^{-1}$ foi enriquecida com $1343 \mathrm{~kg}$ de carbono. Isso representa um acréscimo de $19,5 \%$ de carbono, proporcionado pelo tratamento "40+K" em relação à testemunha. Observa-se portanto que, além da matéria orgânica aplicada diretamente com o biossólido, há um efeito indireto através do aumento da matéria orgânica depositada pelas árvores, o que confirma o efeito acumulativo e de longo prazo do biossólido, que altera o ciclagem biogequímica em eucalipto.

O acompanhamento mensal da deposição de folhedo mostrou que houve maior efeito dos tratamentos, no mês de abril, quando ocorreram os picos de produção (Tabela 6).

Tabela 6. Deposição média mensal $(\mathrm{N}=4)$ de folhedo de eucalipto, durante o período de setembro de 1999 a agosto de 2000, nos tratamentos testados: testemunha (tt), adubação mineral (ad), $10 \mathrm{t} \mathrm{ha}^{-1}$ de biossólido mais K.e $\mathrm{P}$ na base $(10+\mathrm{KP}), 20 \mathrm{t} \mathrm{ha}^{-1}$ de biossólido mais $\mathrm{K}(20+\mathrm{K})$ e $40 \mathrm{t} \mathrm{ha}^{-1}$ de biossólido mais $K(40+K)$

\begin{tabular}{cccccc}
\hline MESES & $\mathbf{5}$ & \multicolumn{5}{c}{ TRATAMENTOS } \\
& $\mathbf{t t}$ & $\mathbf{a d}$ & $\mathbf{1 0 + K P}$ & $\mathbf{2 0 + K}$ & $\mathbf{4 0 + K}$ \\
\hline $09 / 99$ & 35 & 82 & 127 & 74 & 83 \\
$10 / 99$ & 21 & 50 & 62 & 68 & 94 \\
$11 / 99$ & 64 & 135 & 201 & 218 & 300 \\
$12 / 99$ & 66 & 101 & 117 & 121 & 170 \\
$01 / 00$ & 208 & 372 & 380 & 274 & 390 \\
$02 / 00$ & 297 & 541 & 567 & 425 & 599 \\
$03 / 00$ & 395 & 479 & 564 & 492 & 613 \\
$04 / 00$ & 390 & 647 & 986 & 744 & 1497 \\
$05 / 00$ & 157 & 273 & 398 & 340 & 457 \\
$06 / 00$ & 234 & 526 & 199 & 296 & 257 \\
$07 / 00$ & 46 & 86 & 51 & 57 & 56 \\
$08 / 00$ & 63 & 85 & 95 & 126 & 145 \\
\hline
\end{tabular}


Durante praticamente todos os meses, as plantas do tratamento que recebeu a maior dose de biossólido $(40+K)$, depositaram mais folhedo do que as dos outros tratamentos $e$ as plantas testemunhas produziram as menores quantidades. Isso mostra que a aplicação de biossólido altera os padrões de deposição de folhedo e, consequentemente, a ciclagem dos nutrientes.

No mês de abril houve um aumento considerável na queda de folhas, principalmente, no tratamento "40+K" e "10+KP". Pôde ser observado no campo, que houve uma seca das folhas e dos galhos mais baixos das árvores, o que determinou essa queda acentuada de folhas. Nesse mês, houve um periodo de baixa precipitação pluviométrica e aumento da amplitude térmica (Figura 2), o que pode ter determinado um estresse para as plantas e a necessidade de acentuar a ciclagem bioquímica, principalmente nos tratamentos que apresentaram maior crescimento. Esse efeito não se repetiu nos meses seguintes.

Segundo Poggiani (1985), com relação à deposição de folhedo, os eucaliptos apresentam características ecológicas que diferem da maioria das espécies que constituem as florestas naturais. Ao contrário das florestas da região sub-tropical do Brasil, cuja deposição de folhas caducas é maior no período de inverno, os eucaliptos depositam mais folhedo no período envolvendo o final da primavera e o verão. A deposição de folhas pelos eucaliptos não estaria ligada à redução de água no solo e à necessidade de diminuir a perda de água por transpiração, mas sim devido à maior translocação de compostos orgânicos e nutrientes de tecidos mais velhos para tecidos mais novos, que ocorre no período de primavera-verão, quando a temperatura se eleva e ocorre maior desenvolvimento de folhas novas.

Os meses em que as árvores depositaram menos folhedo foram setembro/outubro de 1999 e junho/julho de 2000. Carpanezi (1980), observou menor deposição no período de abril a novembro. Schumacher (1992) observou menor deposição no período da primavera. Os autores citados anteriormente também trabalharam com E. grandis. 


\subsubsection{Teores de nutrientes no folhedo e comparação com os da copa}

$O$ folhedo foi coletado e analisado quimicamente para estimar o reciclagem dos nutrientes através da queda das folhas das árvores. As análises mostram que o teor de Ca nas folhas depositadas aumenta, substancialmente, com a dose de biossólido (Tabela 7).

Tabela 7. Teores médios $(N=4)$ de macronutrientes em folhedo de eucalipto \pm erro padrão da média, depositado nos meses de novembro de 1999 e março de 2000, 16 e 20 meses após aplicação de biossólido

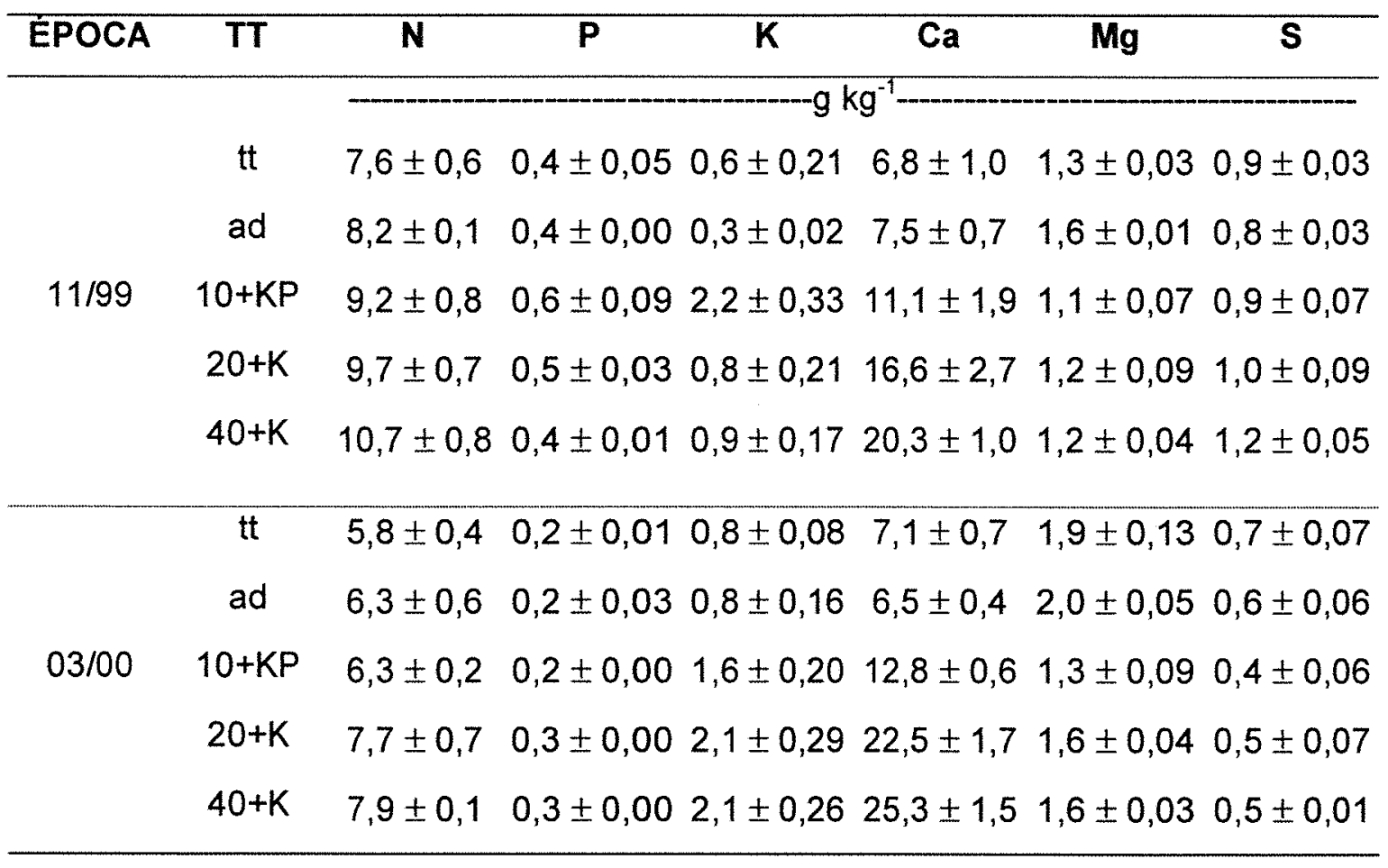

O Ca é praticamente imóvel na planta e se concentra nas folhas velhas e, consequentemente, no folhedo. Assim, o efeito observado no aumento do teor de $\mathrm{Ca}$, é mais nítido no folhedo do que nas folhas do terço superior das copas.

Os teores de $\mathrm{N}$ no folhedo também aumentaram com a dose de biossólido aplicada, apesar da elevada mobilidade desse elemento no floema e da eficiente ciclagem bioquimica do mesmo. As plantas que receberam doses elevadas de biossólido, extraíram $\mathbf{N}$ suficiente para aumentar a concentração 
do nutriente nas folhas senescentes, além do aumento observado nas folhas metabolicamente ativas do terço superior das copas

Pode-se observar na tabela anterior que, em todos os tratamentos, os teores de N, P e S, são maiores na primeira época de coleta (11/99) e que os teores de $\mathrm{K}, \mathrm{Ca}$ e Mg são maiores na segunda época (03/00). A primeira coleta foi realizada após um período de menor precipitação pluviométrica, quando comparada com a segunda (Figura 2). Independente do tratamento, o clima mais seco favoreceu o acúmulo no folhedo dos nutrientes que se encontram na planta, predominantemente, na forma orgânica $(N, P, S)$. De maneira contrária, o clima mais chuvoso favoreceu o acúmulo no folhedo dos nutrientes que se encontram na planta, predominantemente, na forma mineral $(\mathrm{K}, \mathrm{Ca}, \mathrm{Mg})$.

Analisando os micronutrientes presentes no folhedo, observa-se que houve aumento mais pronunciado no teor de $\mathrm{Zn}$ (Tabela 8), do que foi observado na avaliação nutricional (Figura 12). 
Tabela 8. Teores médios $(\mathrm{N}=4)$ de micronutrientes e do elemento $\mathrm{Na}$ em folhedo de eucalipto \pm erro padrão da média, depositado nos meses de novembro de 1999 e março de 2000, 16 e 20 meses após aplicação de biossólido.

\begin{tabular}{cccccccc}
\hline EPOCA & TT & $\mathrm{Fe}$ & $\mathrm{Cu}$ & $\mathrm{Mn}$ & $\mathrm{Zn}$ & $\mathrm{B}$ & $\mathrm{Na}$ \\
\hline & $\mathrm{Ht}$ & $265 \pm 23$ & $8 \pm 0,53$ & $645 \pm 193$ & $10 \pm 0,68$ & $31 \pm 1,91$ & $1063 \pm 244$ \\
& $\mathrm{ad}$ & $300 \pm 19$ & $5 \pm 0,22$ & $482 \pm 62$ & $10 \pm 0,68$ & $26 \pm 1,35$ & $1088 \pm 270$ \\
$11 / 99$ & $10+\mathrm{KP}$ & $317 \pm 39$ & $6 \pm 0,34$ & $448 \pm 104$ & $11 \pm 1,14$ & $24 \pm 2,32$ & $1563 \pm 38$ \\
& $20+\mathrm{K}$ & $320 \pm 9$ & $7 \pm 1,14$ & $435 \pm 30$ & $13 \pm 1,21$ & $25 \pm 1,21$ & $1250 \pm 353$ \\
& $40+\mathrm{K}$ & $335 \pm 24$ & $8 \pm 0,41$ & $410 \pm 37$ & $15 \pm 2,00$ & $28 \pm 2,23$ & $1175 \pm 159$ \\
& $\mathrm{Ht}$ & $110 \pm 9$ & $7 \pm 1,13$ & $752 \pm 95$ & $4 \pm 0,66$ & $34 \pm 0,97$ & $410 \pm 90$ \\
& ad & $121 \pm 12$ & $2 \pm 1,09$ & $486 \pm 29$ & $3 \pm 0,29$ & $33 \pm 1,20$ & $448 \pm 173$ \\
& $10+\mathrm{KP}$ & $176 \pm 24$ & $2 \pm 0,25$ & $482 \pm 42$ & $4 \pm 0,70$ & $34 \pm 1,36$ & $728 \pm 101$ \\
& $20+\mathrm{K}$ & $130 \pm 15$ & $4 \pm 0,70$ & $524 \pm 15$ & $7 \pm 1,13$ & $31 \pm 1,29$ & $698 \pm 174$ \\
& $40+\mathrm{K}$ & $761 \pm 619$ & $5 \pm 0,43$ & $444 \pm 32$ & $7 \pm 0,50$ & $33 \pm 0,49$ & $650 \pm 76$
\end{tabular}

A diminuição do teor de $\mathrm{Mn}$ no folhedo com o aumento da dose, mostra que o elemento não está se concentrando em folhas velhas, como podería-se supor pela sua baixa mobilidade. Realmente, as plantas cultivadas onde foi aplicado mais biossólido diminuem a absorção de $\mathrm{Mn}$.

Já, o $\mathrm{Fe}$, elemento também pouco móvel, aumentou sua concentração nas folhas velhas com o aumento da dose, apesar de também apresentar tendência de diminuição nas folhas do terço superior da copa. No entanto, o elevado valor desse elemento observado no tratamento que recebeu a maior dose de biossólido $(40+K)$, na coleta de março de 2000 , não é significativo, já que o erro padrão da média é muito elevado. 
Comparando-se os teores dos nutrientes no folhedo com os teores nas folhas do terço superior da copa, pode-se inferir sobre a mobilidade do nutriente dentro da planta. A figura abaixo mostra essa comparação para o N (Figura 14).
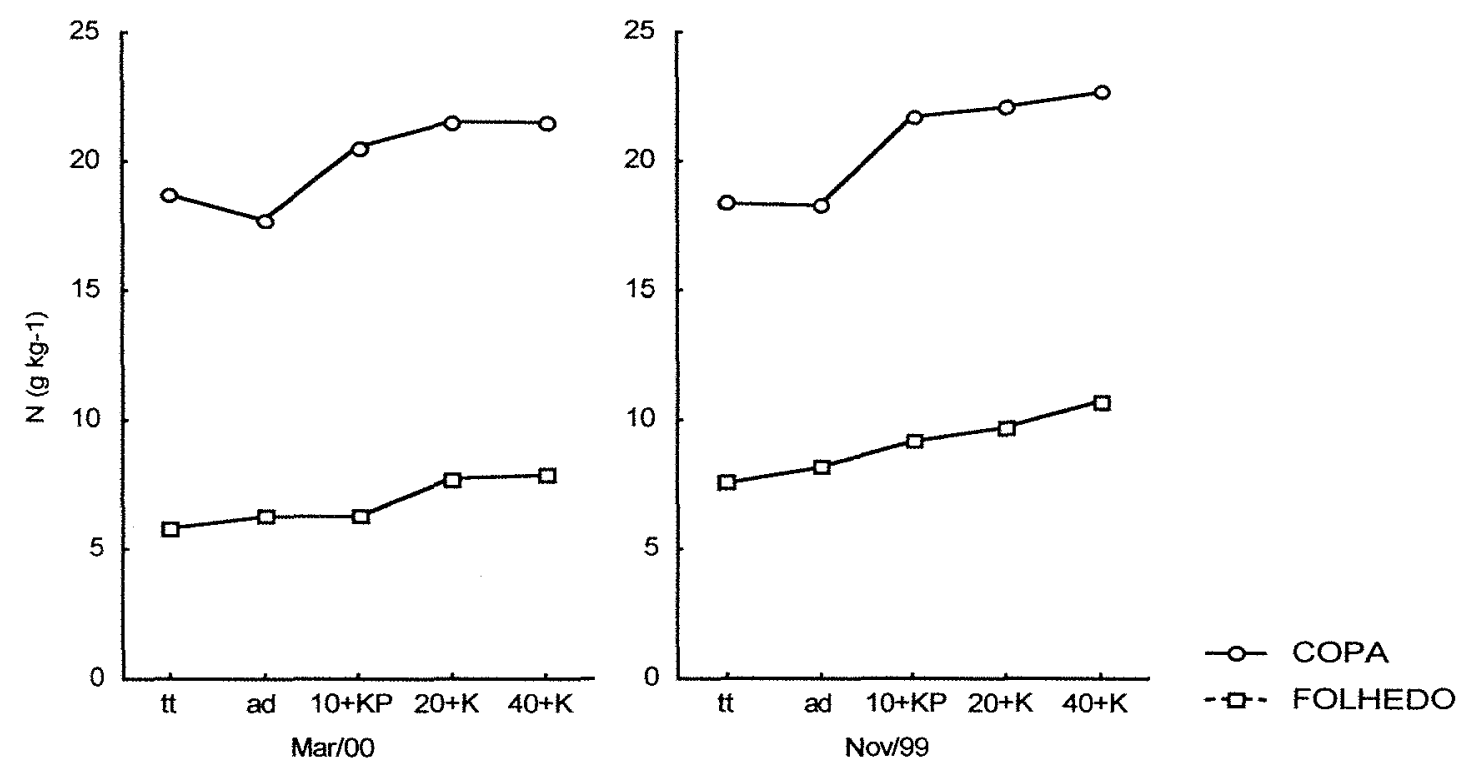

Figura 14. Teores médios $(\mathrm{N}=4)$ de $\mathrm{N}$ em folhas das copas e no folhedo depositado, 16 meses (Nov/99) e 20 meses (Mar/00) após aplicação de biossólido.

Pode-se o observar que $\mathrm{N}$ é mais concentrado nas folhas da copa, indicando que esse elemento é ciclado, bioquimicamente, com grande eficiência. Observa-se que as diferenças entre os teores na copa e no folhedo não aumentam com a aplicação de biossólido, indicando que a taxa de reciclagem bioquímica não foi afetada pelo biossólido. Ao contrário, a diferença entre o teor de Ca no folhedo e na copa, aumenta com as doses, principalmente na coleta de março de 2000 (Figura 15). 

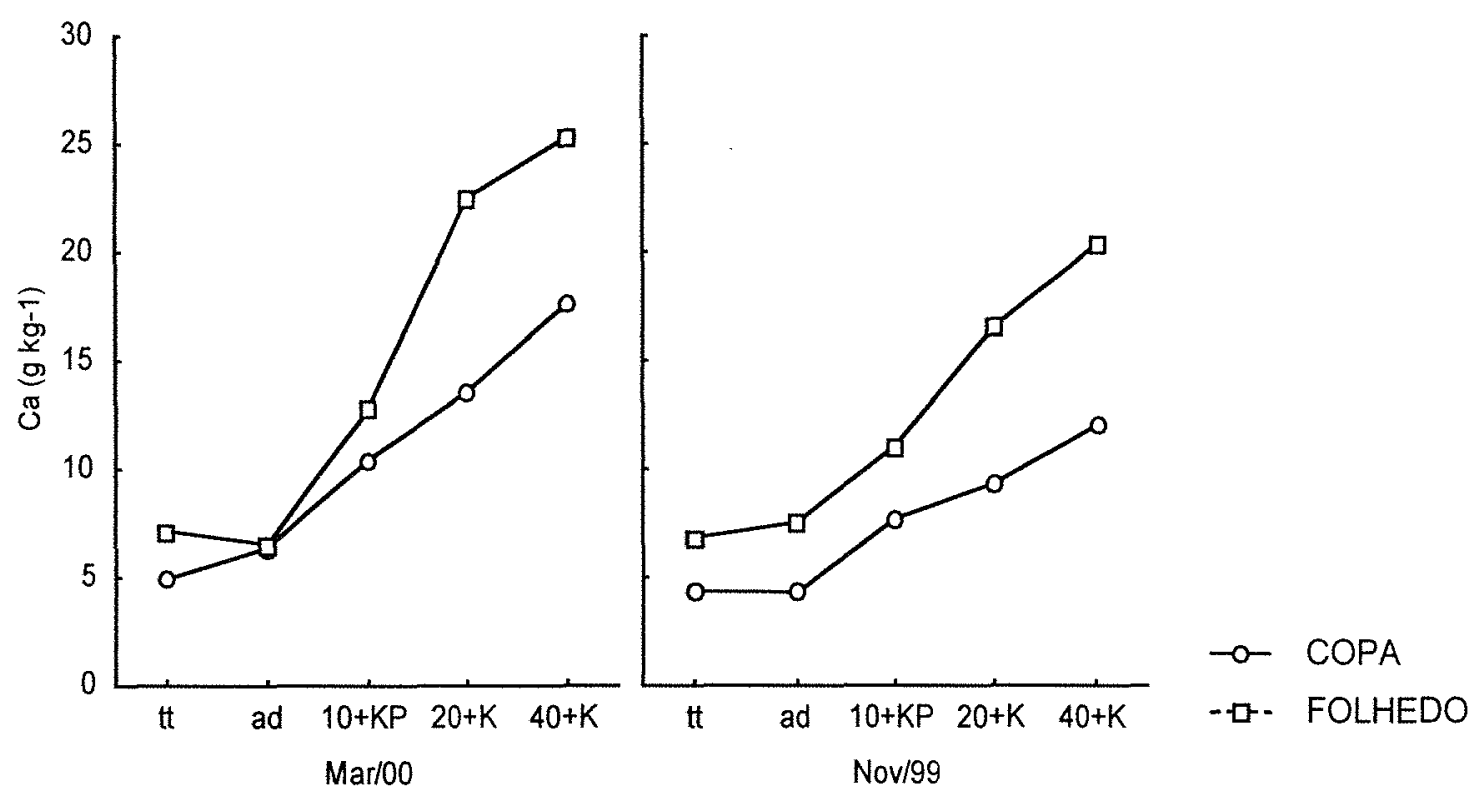

Figura 15. Teores médios $(\mathrm{N}=4)$ de $\mathrm{Ca}$ em folhas das copas e no folhedo depositado, 16 meses (Nov/99) e 20 meses (Mar/00) após aplicação de biossólido.

Como o biossólido é muito rico em $\mathrm{Ca}$ e este é um elemento que, praticamente, não apresenta ciclagem bioquímica (por ser um elemento estrutural, uma vez imobilizado em algum tecido, dificilmente ele vai ser retranslocado), quanto mais ele for absorvido mais se concentrará nas folhas velhas. Esse efeito é mais nítido na coleta de março de 2000, principalmente para os tratamentos " $20+K$ " e " $40+K$ ". Essa coleta foi realizada após período de intensa precipitação (Figura 2), que contribui para maior solubilização do Ca do biossólido e consequente disponibilização para as plantas.

\subsubsection{Deposição de nutrientes via folhedo}

Multiplicando-se a biomassa seca pelo teor de cada nutriente no folhedo, pode-se estimar o conteúdo de nutrientes que é depositado e reciclado no ciclo biogeoquímico, com a deposição das folhas. 
A Tabela 9 mostra os conteúdos dos nutrientes no folhedo depositado nos meses de novembro de 1999 e março de 2000. Pode-se observar que o conteúdo de nutrientes em todos os tratamentos e para todos os elementos, foi maior na segunda época de coleta $(03 / 00)$. Nessa época houve maior produção de folhedo, em todos os tratamentos, o que determina aumento no conteúdo de nutrientes, mesmo para aqueles elementos que, nessa época ficaram menos concentrados no folhedo.

Tabela 9. Conteúdo de nutrientes em folhedo depositado pelo eucalipto nos meses de novembro de 1999 e março de 2000.

\begin{tabular}{|c|c|c|c|c|c|c|c|c|c|c|c|}
\hline EPOCA & TT & $\mathbf{N}$ & $\mathbf{P}$ & $\mathbf{K}$ & $\mathrm{Ca}$ & Mg & $\mathbf{S}$ & $\mathrm{Fe}$ & $\mathrm{Cu}$ & $M n$ & Zn \\
\hline & & & 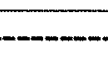 & $--\mathrm{kg} \mathrm{h}$ & $1 a^{-1}-\cdots$ & 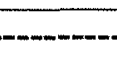 & $-\cdots$ & $-\cdots$ & $-\mathrm{g}$ ha & -1...... & $-\cdots$ \\
\hline & $\mathrm{tt}$ & 0,5 & 0,02 & 0,06 & 0,36 & 0,08 & 0,06 & 18 & 0,6 & 38 & 0,7 \\
\hline & $\mathrm{ad}$ & 1,1 & 0,06 & 0,04 & 1,01 & 0,22 & 0,11 & 41 & 0,7 & 64 & 1,3 \\
\hline \multirow[t]{5}{*}{$11 / 99$} & $10+K P$ & 1,8 & 0,11 & 0,42 & 2,34 & 0,22 & 0,19 & 66 & 1,2 & 98 & 2,2 \\
\hline & $20+K$ & 2,1 & 0,11 & 0,17 & 3,80 & 0,25 & 0,21 & 70 & 1,5 & 97 & 2,8 \\
\hline & $40+K$ & 3,2 & 0,13 & 0,28 & 6,08 & 0,35 & 0,37 & 101 & 2,4 & 124 & 4,4 \\
\hline & $\mathrm{tt}$ & 2,4 & 0,07 & 0,30 & 2,89 & 0,75 & 0,26 & 42 & 2,9 & 287 & 1,7 \\
\hline & ad & 3,1 & 0,10 & 0,42 & 3,07 & 0,96 & 0,30 & 57 & 1,1 & 231 & 1,6 \\
\hline \multirow[t]{3}{*}{$03 / 00$} & $10+K P$ & 3,5 & 0,13 & 0,92 & 7,22 & 0,76 & 0,24 & 99 & 1,3 & 272 & 2,3 \\
\hline & $20+K$ & 3,7 & 0,13 & 1,01 & 10,93 & 0,77 & 0,21 & 65 & 2,1 & 256 & 3,3 \\
\hline & $40+K$ & 4,8 & 0,19 & 1,25 & 15,51 & 0,96 & 0,30 & 545 & 3,9 & 269 & 4,5 \\
\hline
\end{tabular}

Pode-se observar que o efeito do biossólido sobre o aumento da quantidade de nutrientes retornada ao solo com a queda das folhas, é considerável. As áreas onde foram aplicadas quarenta toneladas de biossólido, receberam sempre mais nutrientes, do que as parcelas dos outros tratamentos. Por exemplo, considerando os dois meses analisados, as plantas do tratamento " $40+K$ " retornaram ao solo, duas vezes mais $\mathrm{N}$ do que as plantas que 
receberam adubação mineral, sete vezes mais $\mathrm{Ca}$ e três vezes mais $\mathrm{Zn}$ do que as plantas testemunhas.

\subsubsection{Acúmulo de folhedo sobre o solo}

A Tabela 10 mostra os valores de biomassa do folhedo seco acumulado nas parcelas dos tratamentos testados, durante as quatro épocas de coleta e a média das quatro épocas. $O$ folhedo coletado durante o mês de fevereiro de 2000 , apresentou os menores valores, para todos os tratamentos. Nos meses anteriores a fevereiro, principalmente dezembro e janeiro, foram registrados elevados índices pluviométricos e aumento da temperatura ambiente (Figura 2), fato este que favoreceu a decomposição do material e o menor acúmulo em fevereiro.

Durante o período de fevereiro a maio de 2000 , a quantidade de folhedo acumulado aumentou em todos os tratamentos, coincidindo com o período de menor precipitação, que dificulta a decomposição e incorporação do material orgânico ao solo. 
Tabela 10. Valores médios ( $N=12)$ ! o erro padrão da média, de peso seco do folhedo acumulado sobre o solo em cada época de coleta e média das quatro épocas $(\mathrm{N}=48)$. As médias seguidas por letras iguais não diferem entre si, pelo teste de Tukey a $5 \%$ de probabilidade.

\begin{tabular}{lcccccc}
\hline data de coleta & Tt & ad & TRATAMENTOS & 10 KP & $\mathbf{2 0}+\mathrm{K}$ & $\mathbf{4 0}+\mathrm{K}$ \\
\hline $08 / 99$ & $3952 ! 333$ & $4310 ! 148$ & $4970 ! 363$ & $4368 ! 283$ & $5045 ! 296$ \\
$02 / 00$ & $810 ! 186$ & $1612 ! 156$ & $1106 ! 118$ & $1364 ! 291$ & $1334 ! 156$ \\
$05 / 00$ & $1603 ! 163$ & $3288 ! 235$ & $3270 ! 162$ & $2783 ! 240$ & $3397 ! 146$ \\
$08 / 00$ & $1701 ! 292$ & $3824 ! 277$ & $3852 ! 234$ & $2755 ! 253$ & $3667 ! 209$ \\
média & $2016 \mathbf{a}$ & $3258 \mathbf{b c}$ & $3300 \mathbf{b}$ & $2818 \mathrm{c}$ & $3361 \mathbf{b}$ \\
\hline
\end{tabular}

A quantidade de folhedo acumulado na área testemunha foi, significativamente, menor do que em todos os tratamentos testados $(p<0,001)$.

Considerando $O$ aspecto dinâmico da ciclagem dos nutrientes, pode-se inferir que a quantidade de folhedo acumulado sobre o solo é função da quantidade que é depositada pelas árvores, assim como da quantidade que sofre decomposição. 


\subsubsection{Decomposição do folhedo}

Utilizando os dados de folhedo acumulado sobre o solo e folhedo depositado pelas árvores, calcula-se a taxa de decomposição instantânea e os índices derivados dela, de acordo com a equação matemática estabelecida por Olson (1963). Os resultados são apresentados na Tabela 11.

Tabela 11. Taxa instantânea de decomposição (K), tempo médio de renovação (1/K) e tempo necessário para decomposição de $50 \%$ das folhas acumuladas na serapilheira $\left(t_{0,5}\right)$, em função dos tratamentos testados.

\begin{tabular}{cccc}
\hline Tratamento & $\mathrm{K}$ & $1 / \mathrm{K}$ (anos) & $\mathrm{t}_{0,5}$ (anos) \\
\hline $\mathrm{tt}$ & 0,98 & 1,02 & 0,71 \\
$\mathrm{ad}$ & 1,02 & 0,98 & 0,68 \\
$10+\mathrm{KP}$ & 1,13 & 0,88 & 0,61 \\
$20+\mathrm{K}$ & 1,15 & 0,87 & 0,60 \\
$40+\mathrm{K}$ & 1,39 & 0,72 & 0,50 \\
\hline
\end{tabular}

O folhedo produzido pelas plantas do tratamento testemunha (tt) apresentou a menor taxa de decomposição, enquanto que o tratamento onde foi aplicada a maior dose de biossólido, apresentou a maior taxa, assim como menor tempo de renovação e tempo de meia vida. O tratamento "40+K" aumentou em $40 \%$ a decomposição do folhedo, quando comparado com o tratamento testemunha. Esse fato indica que 0 biossólido acelera a decomposição do folhedo depositado e a liberação de nutrientes para serem reciclados pelas plantas. Esse efeito pode ser atribuído a fatores como: melhor qualidade do folhedo produzido com biossólido (mais rico em nutrientes, principalmente $\mathrm{N}$ ) e maior ativação da mesofauna e dos microorganismos do solo, devido ao aumento da matéria orgânica e melhoria da fertilidade da área onde foi aplicado o resíduo. Poggiani (1985), encontrou valor de $K=0,56$, para folhedo depositado em um povoamento de Eucaliptos saligna. 


\subsection{Biomassa e nutrientes na vegetação de sub-bosque}

O sub-bosque da área é constituído por ervas, arbustos e mudas de árvores nativas, que se desenvolvem sob a copa dos eucaliptos. Em uma caracterização inicial da área, antes da aplicação do biossólido, observou-se que as espécies mais comuns que estavam desenvolvendo-se na área foram: Caryocar brasiliensis, Solanum variable, Smilax sp., Dalbergia miscolobium e Anadenanthera falcata.

A análise de variância da regressão dos valores de biomassa sobre as doses crescentes de biossólido não foi significativa ao nivel de $95 \%$ de confiança, tanto para as gramíneas $(p=0,34)$ quanto para as não gramíneas $(p=0,06)$.

$\mathrm{Na}$ Tabela 12 são apresentados os valores médios de biomassa estimada do sub-bosque. Mesmo sem significância dos tratamentos e consciente da grande variação existente, como também constatado no campo, é importante apresentar os valores observados, já que dados referentes à quantificação da biomassa de sub-bosque de eucaliptos não foram encontrados na literatura.

Tabela 12. Valores médios $(\mathrm{N}=36)$ ! desvio padrão, de biomassa seca do subbosque do eucalipto, para cada dose de biossólido complementado com potássio e tipo de material vegetal (TMV): não gramíneas (NG), gramíneas (G).

\begin{tabular}{|c|c|c|c|c|}
\hline \multirow[t]{2}{*}{ TMV } & \multicolumn{4}{|c|}{ doses de biossólido $\left(\mathrm{t} \mathrm{ha}^{-1}\right)$} \\
\hline & 0 & 10 & 20 & 40 \\
\hline & 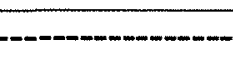 & ---biomassa & $\left(\mathrm{kg} \mathrm{ha}^{-1}\right)-\cdots$ & ------- \\
\hline NG & $89 \pm 112$ & $66 \pm 51$ & $125 \pm 133$ & $130 \pm 140$ \\
\hline G & $115 \pm 136$ & $103 \pm 147$ & $477 \pm 693$ & $156 \pm 248$ \\
\hline
\end{tabular}

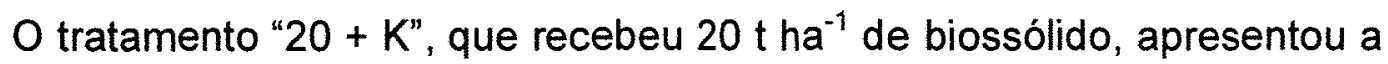
mais elevada quantidade média de gramíneas no sub-bosque. No entanto, esse fato foi observado em apenas dois blocos, o que determina elevada variação em torno da média e a não significância estatistica das diferenças em relação 
aos outros tratamentos. Coincidentemente, nos mesmos blocos onde isso aconteceu, pôde-se observar também menor desenvolvimento das plantas de eucalipto que receberam 20t ha ${ }^{-1}$ de biossólido. Nesses blocos pode estar ocorrendo competição entre gramíneas e os eucaliptos. Com o menor crescimento dos eucaliptos, há maior penetração de luz até o sub-bosque, favorecendo ainda mais o desenvolvimento das gramíneas.

$\mathrm{Na}$ média das três coletas, a biomassa de gramíneas, em todos os tratamentos, foi maior do que a biomassa de não gramíneas. Analisando as diferenças entre os dois tipos de vegetação, encontra-se, que na área testemunha, a biomassa de gramíneas foi $29 \%$ maior, enquanto que na área que recebeu $10 \mathrm{t} \mathrm{ha}^{-1}$ de biossólido $56 \%$, na que recebeu $20 \mathrm{t} \mathrm{ha}^{-1}$ de biossólido $282 \%$ e na que recebeu $40 \mathrm{t} \mathrm{ha}^{-1}$ de biossólido apenas $20 \%$. Verifica-se, protanto, que a aplicação de biossólido, nas doses de $10 \mathrm{t} \mathrm{ha}^{-1} \mathrm{e}$, principalmente, na de $20 \mathrm{t} \mathrm{ha}^{-1}$, tende a favorecer o desenvolvimento das espécies gramíneas. Provavelmente, a tendência de maior efeito do biossólido sobre as gramíneas é devido ao fato de que a maioria das espécies dessa família não são fixadoras de $\mathrm{N}_{2}$ atmosférico e respondem melhor ao elevado teor de $\mathrm{N}$ do biossólido.

A seguir são apresentados os teores de alguns nutrientes, no material vegetal coletado no sub-bosque (Figura 16). 

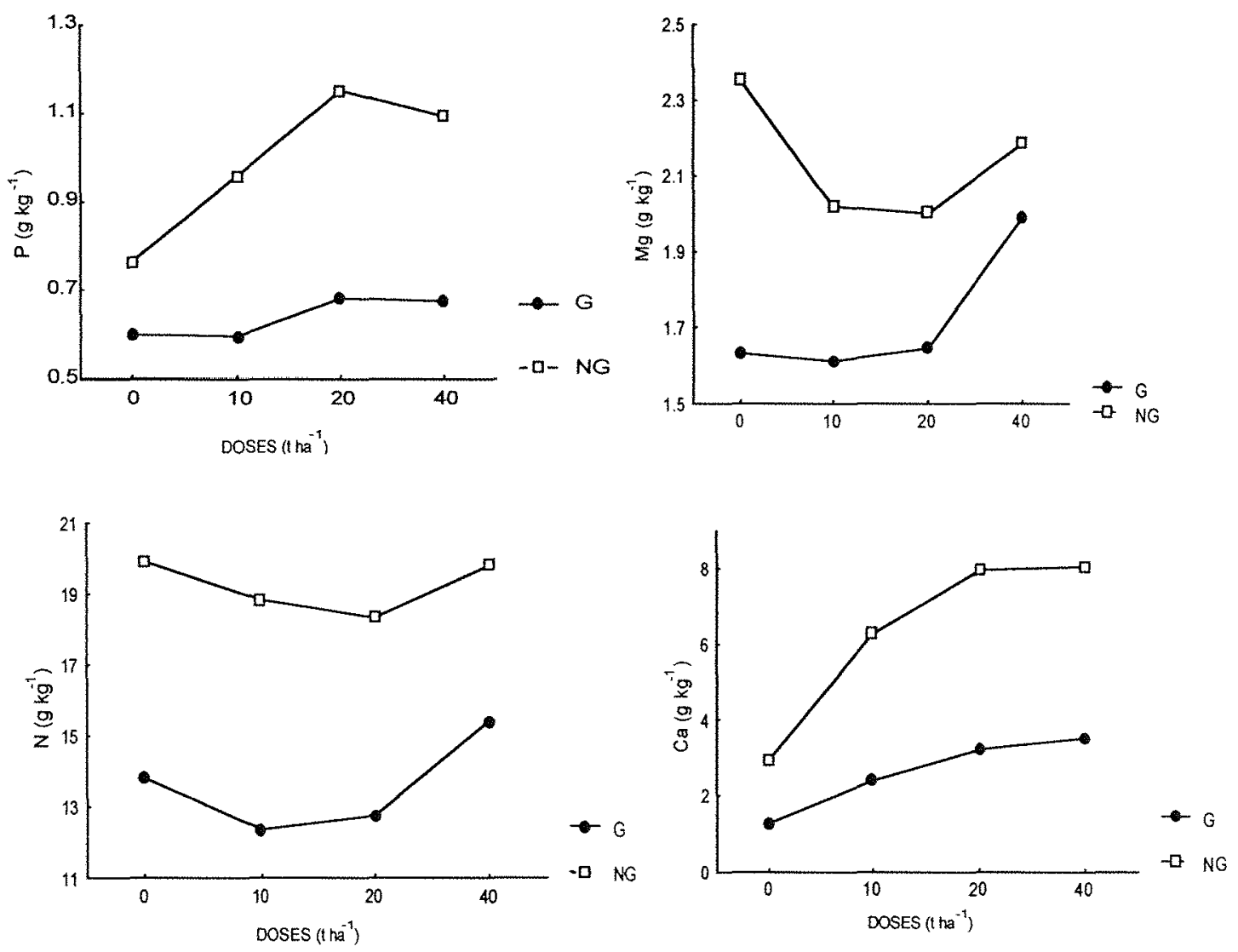

Figura 16. Teores médios ( $N=12,4$ repetições e 3 coletas) de macronutrientes em vegetação de sub-bosque de eucalipto, de acordo com o tipo de material vegetal (TMV), gramíneas (G) ou não gramíneas (NG) e doses de biossólido complementado com $\mathrm{K}$.

A vegetação de não gramíneas apresentou maior concentração dos macronutrientes do que as gramíneas, sendo que essa diferença diminui com o aumento da dose para o $\mathrm{N} \mathrm{e} \mathrm{Mg} \mathrm{e} \mathrm{aumenta} \mathrm{para} \mathrm{o} \mathrm{Ca}$ e $\circ \mathrm{P}$. Isso indica que as gramíneas aproveitam mais $\circ \mathrm{N}$ do biossólido do que as não gramíneas, naturalmente mais concentradas nesse elemento como pode ser visto no tratamento testemunha. Já para o $\mathrm{Ca}$, o inverso pode ser observado. Apesar do teor nas gramíneas aumentar com a dose, o aumento das não gramíneas é maior. 
De maneira geral, as gramíneas do sub-bosque apresentam concentrações, naturalmente, muito elevadas de Fe. Mesmo com a aplicação de biossólido, as gramíneas mantiveram sempre maior concentração em Fe do que as não gramíneas. No entanto, o teor de Mn apresentou comportamento inverso. Naturalmente, mais concentrado nas não gramíneas, com a aplicação de biossólido, ficou sempre mais concentrado nas gramíneas.

Multiplicando-se o teor de diferentes nutrientes pela biomassa do subbosque, pode-se estimar o conteúdo de nutrientes imobilizados no sub-bosque (Tabela 13).

Tabela 13. Conteúdo total de nutrientes na vegetação, gramíneas mais não gramíneas, de sub-bosque de eucalipto, em função de doses de biossólido complementado com K.

\begin{tabular}{|c|c|c|c|c|c|c|c|c|c|c|c|c|}
\hline DOSE & $N$ & $P$ & $\mathrm{~K}$ & $\mathrm{Ca}$ & $\mathrm{Mg}$ & $S$ & $\mathrm{Fe}$ & $\mathrm{Cu}$ & $\mathrm{Mn}$ & $\mathrm{Zn}$ & $\mathrm{Na}$ & $B$ \\
\hline & & & $\cdots-k$ & a & & 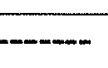 & & & $\mathrm{gh}$ & & & - \\
\hline 0 & 3,63 & 0,14 & 1,22 & 0,43 & 0,41 & 0,40 & 110 & 2 & 51 & 6 & 60 & 4 \\
\hline 10 & 2,45 & 0,13 & 1,18 & 0,67 & 0,31 & 0,28 & 105 & 2 & 45 & 5 & 46 & 3 \\
\hline 20 & 8,93 & 0,46 & 3,97 & 2,24 & 0,91 & 0,93 & 433 & 5 & 113 & 17 & 176 & 11 \\
\hline 40 & 4,91 & 0,26 & 2,18 & 1,66 & 0,62 & 0,51 & 146 & 3 & 56 & 8 & 58 & 6 \\
\hline
\end{tabular}

Observa-se maior acúmulo de nutrientes na vegetação de sub-bosque desenvolvida na área que recebeu $20 \mathrm{t} \mathrm{ha}^{-1}$ de biossólido, área esta onde os eucaliptos se desenvolveram menos e não acompanharam a curva de crescimento. 


\subsection{Luz incidente no sub-bosque}

A medição da luz solar difusa, sob as copas dos eucaliptos, fornece uma boa estimativa da cobertura do dossel e da biomassa foliar acumulada nas copas dos eucaliptos. Sabe-se que a penetração da energia solar no subbosque decresce em função da porcentagem de cobertura do dossel.

Os valores da radiação, medidos em área aberta a pleno sol foram: 1380 , $1440,1640,1430$ e $1420 \mathrm{Mmol} \mathrm{cm}^{-2} \mathrm{~s}^{-1}$. Em geral, aproximadamente, $10 \% \mathrm{da}$ luz disponível acima das copas, atravessou o dossel e foi medida como luz difusa a $1 \mathrm{~m}$ do solo. $\mathrm{O}$ tratamento que recebeu a maior dose de biossólido, apresentou o menor valor de luz incidente sob o dossel e a menor variação em torno da média (Figura 17).

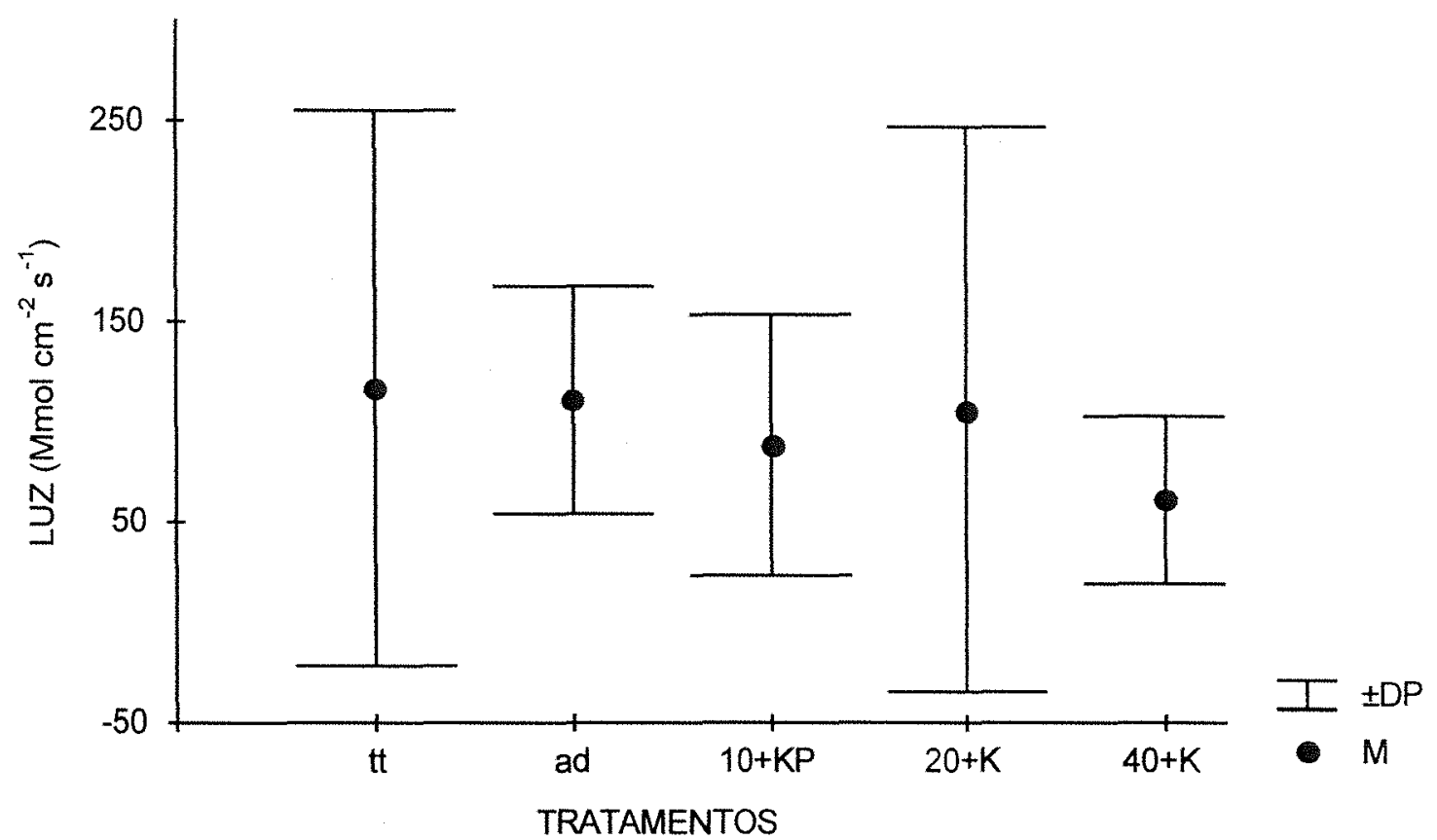

Figura 17. Valores médios (M) e dos desvios padrões (DP) de luz difusa incidente sob as copas dos eucaliptos, medidos em junho de 2000, 27 meses após o plantio $(\mathrm{N}=64)$.

A entrada de menos luz difusa no tratamento que recebeu a maior dose de biossólido, " $40+K$ ", indica que as plantas desse tratamento, encontram-se com as copas mais desenvolvidas $e$ fechadas, propiciando maior 
sombreamento da área, e provavelmente com maior biomassa de galhos e folhas.

O tratamento "20+K" apresentou maior valor de luz sob o dossel do que o tratamento "10+KP", no entanto o valor médio do tratamento " $20+K "$ apresentou desvio padrão muito elevado (106 Mmol cm $\mathrm{s}^{-1} \pm 140$ ), mostrando grande variação. Apenas nas parcelas de dois blocos da área, as mesmas parcelas onde foram observados maior crescimento de gramíneas e menor desenvolvimento das plantas de eucalipto, é que maior quantidade de luz atravessou o dossel do tratamento "20+K". Provavelmente, há uma interação entre esses três fatores, nas parcelas do tratamento " $20+K "$ localizadas nos dois blocos, em função de maior mortalidade e replantio das mudas nessas parcelas. 


\section{CONCLUSÕES}

Os vários resultados obtidos confirmam a hipótese de que a aplicação do biossólido altera o desenvolvimento e o estado nutricional das plantas, bem como os padrões de ciclagem dos nutrientes. No entanto, a falta dé referências de estudos semelhantes dificulta um aprofundamento na discussão dos resultados, exigindo uma análise muito mais criteriosa das variáveis medidas e cautela nas conclusões tiradas.

Analisando os objetivos específicos propostos, pode-se chagar às seguintes conclusões:

1) a aplicação de biossólido modificou o estado nutricional das plantas de eucalipto. Aquelas que receberam mais biossólido, apresentaram teores foliares mais elevados de N, P, Ca, S e teores mais baixos para o Mg e Mn.

2) a aplicação de biossólido aumentou a produção de folhedo e consequente deposição de nutrientes, bem como a decomposição do folhedo acumulado sobre o solo, alterando o processo de ciclagem biogeoquímica;

3) a aplicação de biossólido não alterou, de maneira significativa, a biomassa produzida pela vegetação do sub-bosque: A vegetação de gramíneas sempre apresentou concentrações mais elevadas dos nutrientes do que as não gramíneas. 


\section{REFERÊNCIAS BIBLIOGRÁFICAS}

ANDRADE, C.A. Nitratos e metais pesados em solos e plantas de Eucalyptus grandis após aplicação de biossólido da ETE Barueri. Piracicaba, SP, 1999. 65p. Dissertação (Mestrado) - Escola Superior de Agricultura "Luiz de Queiroz", Universidade de São Paulo.

ARNOLD, K.; MAGAI, R.; HOORMANN, R.; MILES, R. Safety and benefits of biosolids. $\quad h$ http://mnextension.missouri.edu/xplor/waterq/wq0427.htm (janeiro de 1996)

ASSOCIAÇÃO BRASILEIRA DE CELULOSE E PAPEL. Relatório Estatístico Florestal, BRACELPA, 1999. $60 p$.

ASSUNÇÃO, J.C.B. de Análise mineralógica, geoquímica e textural de lodos gerados e dispostos pela ETE de Barueri-SP: associações com metais pesados e seus efeitos no solo. São Paulo, SP, 1995. 120 p. Dissertação (Mestrado) - Instituto de Geociências/USP.

BELLOTE, A.F.J.; SILVA, H.D. Técnicas de amostragem e avaliações nutricionais em plantios de Eucalyptus spp. In: GONÇALVES, J.L.M. e BENEDETTI, V. (eds). Nutrição e fertilização florestal, Piracicaba: IPEF, 2000 , cap 4, p.105-134.

BEKUNDA, M.A. Evaluation of surface applied sewage sludge or a source of inorganic phosphorus in a forest soil. East African Agricultural and Forestry Journal, v.57, n.1, p.47-53, 1991.

BERTON, R.S. Riscos de contaminação do agroecossistema com metais pesados. In: BETTIOL, W. e CAMARGO, O. A. (Eds): Impacto Ambiental do Uso Agrícola do Lodo de Esgoto. Jaguariúna: EMBRAPA Meio Ambiente, 2000, cap. 16, p.259-268.

BETTIOL, W.; CARVALHO, P.C.T. Utilização do Lodo de esgoto primário e fertilizantes organo-minerais IPT na cultura do milho. Fertilizantes, v.4, n.1, p.14-15, 1982. 
BETTIOL, W.; CARVALHO, P.C.T.; FRANCO, B.J.D.C. Utilização do Lodo de esgoto como fertilizante. O solo, v.75, n.1, p.44-54, 1982.

BOARETO, A.E.; MURAO, K.A.T.; NAKAGAUA, J.; CHITOLINA, J.C. Níquel e Cádimo em grãos de feijão produzidos em solo incubado com Le. In: REUNIÃO BRASILEIRA DE FERTILIDADE DO SOLO E NUTRIÇÃO DE PLANTAS, 20, Piracicaba, 1992. Anais. Campina:, Fundação Cargil, 1992. p. 400-1

CARPANEZZI, A. P. Deposição de material orgânico e nutrientes em uma floresta natural e em uma plantação de eucaliptos no interior do Estado de São Paulo. Piracicaba, SP, 1980, 107 p. Tese (Mestrado) - Escola Superior de Agricultura "Luiz de Queiroz", Universidade de São Paulo.

CARVALHO, P.C.T.; BARRAL, M.F. Aplicação de Le como fertilizante. Fertilizantes, v. 63 , n. 2, p.1-4, 1981.

CHANEY, R.L. Public health and sludge utilization. Biocycle, v.30, p.68-73, 1990.

COMPANHIA DE TECNOLOGIA DE SANEAMENTO AMBIENTAL. (Manual técnico). P 4.230. ago./1999. Aplicação de lodos de sistemas de tratamento biológico em áreas agrícolas - Critérios para projeto e operação. São Paulo, CETESB, 1999. $32 \mathrm{p}$.

ESTADOS UNIDOS (EUA), Department of Agriculture - USDA. Report and recomendation on organic farming. Washington, 1980. 94p.

FARIA, L.C. de; RODRIGUES, L.C.E. Aplicabilidade de biossólido em plantações florestais: $V$. avaliação do potencial de uso do resíduo da ETE de Barueri, SP. In: BETTIOL, W. e CAMARGO, O. A. (Eds): Impacto Ambiental do Uso Agrícola do Lodo de Esgoto. Jaguariúna: EMBRAPA Meio Ambiente, 2000 , cap. 12, p.209-213

FORTUNY, J.A.; FULLER, W.H. Trace metals in municipal sludges. Evaluation procedures for solid wastes. Biocycle, v.20, p.27-29, 1979.

FAO. Organic recycling in Asia. FAO Soils Bullettin, v.36, p.320-325, 1978.

FISKELL, J.G.A.; NEARY, D.G.; COMERFORD, N.B. Slach pine and understorey interception of micronutrients mineralized from sewage sludge applied to a sandy acidic forest soil. Forest Ecology and Management, v.37, n.1/3, p.27-36, 1990. 
GIORDANO, P.M.; MAYS, D.A. Plant nutrient from municipal sewage sludge. Industry and Engeneering Chemistry Product and Researsh Development, Washington, D.C., 1981, v.20, n.2, p.212-216.

GONÇALVES, J.L.M.; STAPE, J.L.; POGGIANI, F.; VAZ, L.M.S.; MOREIRA, R.M. Efeito do lodo de esgoto na fertilidade do solo e crescimento das árvores (sub-projeto 3). Piracicaba: IPEF/ESALQ/USP - SABESP. a) 1999 (relatório de pesquisa $n^{\circ} 2$ ), b) 2000 (relatório de pesquisa $n^{\circ} 8$ ).

GONÇALVES, J.L. de M.; RAIJ, B. van; GONÇALVES, J.C. Florestais. IN: RAIJ, B. van ; CANTARELLA, H.; QUAGGIO, J.A. e FURLANI, A.M.C. (Eds.). Recomendações de adubação e calagem para o Estado de São Paulo.

2. Ed. Campinas: Instituto Agronômico de Campinas \& Fundação IAC, 1996.

p. 247-259 (Boletim Técnico 100)

GUEDES, M.C.; POGGIANI, F. Dados preliminares sobre nutrição de eucalipto cultivado com lodo de esgoto (biossólido). In: simpósio sobre nutrição e fertilização florestal. IPEF/ESALQ, Piracicaba, SP. CD room

GROVE, T.S., THOMSON, B.D.; MALAJCZUK, N. Nutritional physiology of eucalypts: uptake, distribuition and utilization. In: ATTIWILL, P.M. e ADAMS M.A (eds). Nutrition of Eucalypts. CSIRO Australia, 1996. p. 77-108.

HAAG, H. P. Nutrição mineral de Eucalyputs, Pinus, Araucaria e Gmelina no Brasil. Campinas, Fundação Cargill, 1983. 101p.

HART, J.B.; NGUYEN, P.V.; URIE, D.H.; BROCKWAY, D.G. Silvicultural use of wastewater sludge. Jornal of Forestry, v.?, p.17-24, 1988.

HARRISON, R.B.; HENRY, C.L.; XUE, D.S. Magnesium defeciency in Douglasfir and grand fir growing on a sandy outwash soil amended with sewage sludge. Wastes, Air and Soil Polluition, v.75, n.1/2, p.37-50, 1994.

HENRY, C.L.; COLE, D.W.; HARRISON, R.B.; BENGTSSON, J.; LUNDKVIST, $\mathrm{H}$. Use of municipal sludge to restore and improve site productivity in forestry: the Packe Forest Sludge Research Program. Forest Ecology and Management, v.66, n.1/3, p.137-49, 1994.

HENRY, C.L.; COLE, D.W. Use of biosolids in the forest: technology, economics and regulations. Biomass and Bioenergy, v.13, n.4/5, p.269-277, 1997.

HENRY, C.L.; COLE, D.W.; HINCKLEY, T.M.; HARRISON, R.B. The use of municipal and pulp paper sludges to increase production in forestry. Journal of Sustainable Forestry, v.1, n.3, p.41-45, 1993. 
LANDESBERG, J.J.; GOWER, S.T. Applications of physiological ecology of forest management. San Diego, Academic Press. 1997, 354p.

LABRECQUE, M.; TEODORESCU, T.I.; DAICLE, S. Effect wasterwater sludge on grwnth and heavy metal bioaccumulation os two Salix species. Plant and Soil, v.17, n.1-2, p.303-316, 1995.

LEAL, M.L.S. A análise de dados de experimentos com medidas repetidas. Brasília, DF, 1979, 99p. Dissertação (Mestrado) - Universidade Nacional de Brasilia.

LINDO, P.V.; TAYLOR,R.W.; ADRIANO, D.C.; SHUFORD, W.J. Fractionation of residuals phosphorus in a highly weathered sludge-trested soil: organic phosphorus. Communication Soil Science and. Plant Analisys, v.26, n.15/16, p.2639-2653, 1995.

MAcDONALD, M.A ., HAWKINS, B.J., PRESCOTT, C.E.; KIMMINS, J.P. Growth and foliar nutrition of western red cedar fertilized with sewage sludge, pulp sludge, fish silage, and wood ash on northern Vancouver Island. Canadian Journal of. Forest. Research, v.24, p.297-301, 1993.

MALAVOLTA, E.; VITTI, E.C.; OLIVEIRA, S.A. Avaliação do estado nutricional das plantas (princípios e aplicações). 2. ed. Piracicaba, Associação Brasileira para Pesquisa da Potassa e do Fosfato, 1997. 319 p.

McNAB, W.H.; BERRY, C.R. Distribution of aboveground in three pine species planted on a devasted site amended with sewage sludge or inorganic fertilizer. Forest Science, v.31, n.2, p.373-382, 1985.

MILES R.; BROWN, J.R.; ARNOLD, K. Biosolids glossary of terms. Home page: http://mmextension.missouri.edu/xplor/waterq/wq0449.htm (abril de 1995)

NOVAIS, R.F. de; BARROS, N.F. de; NEVES, J.C.L. Nutrição mineral do eucalipto. In: BARROS, N.F. de e NOVAIS, R.F. de (eds). Relação soloeucalipto, Viçosa, Editora Folha de Viçosa, 1990, cap II, p. 25-98.

OLSON, J.S Energy storage and the balance of producers and decomposers in ecological systems. Ecology, v.44, n.2, p.322-331, 1963.

PHILLIPS, R.P.; FISHER, J.T.; MEXAL, J.G. Fuelwood production utilizing Pinus eldarica and sewage sludge fertilizer. Forest Ecology and Management, v.16, p.95-102, 1986. 
POGGIANI, F. Ciclagem de nutrientes em ecossistemas de plantações florestais de Eucalyptus e Pinus. Implicações silviculturais. Piracicaba, SP, 1985, 211p. Tese (Livre Docência) - Escola Superior de Agricultura "Luiz de Queiroz", Universidade de São Paulo.

POGGIANI, F.; BENEDETTI, V. Aplicabilidade do lodo de esgoto urbano em plantações de eucalipto. Silvicultura, v.80, p.48-52. 1999.

POGGIANI, F., GUEDES, M.C.; BENEDETTI, V. Aplicabilidade de biossólido em plantações florestais: I. reflexo no ciclo dos nutrientes. In: BETTIOL, W. e CAMARGO, O. A. (Eds): Impacto Ambiental do Uso Agrícola do Lodo de Esgoto. Jaguariúna: EMBRAPA Meio Ambiente, 2000, cap. 8, p.163178.

POGGIANI, F; SCHUMACHER, M. V. Atmospheric inputs compared with nutrient removed by harvesting from Eucalyptus plantation. Implications for sustainability. In: "IUFRO Conference on Silviculture and improvement fo Eucalypt". Proceedings. Salvador. Colombo: EMBRAPA. Centro nacional de Pesquisa de Florestas. 1997, 4v., p:68-74.

POLGLASE, P.J.; MYERS, B.J. Tree plantation for recycling effluent and biosolids in Australia. In: ELDRIDGE, K.G. (Ed). Environmental management: the role of eucalypts and other fast growing species. Proceedings of the Joint Australian/Japanese Workshop held in Australia, 1995, p. 100-109.

ROS, C.O.; CERETTA, C.A.; FRIES, M.R. Lodo de esgoto: efeito imediato no milheto e residual na asssociação aveia-ervilhaca. Revista Brasileira de Ciência do Solo, v.17, n.2, p.257-61, 1993.

SABEY, B.R. The use of sewage sludge as a fertilizer. Enviromental Engineering Series, v. 72, p.108-12, 1974.

SANTOS, H.S.; TSUTIYA, M.T. Aproveitamento e disposição final do lodo de estações de tratamento do Estado de São Paulo. Engenharia Sanitária e Ambiental, v.2, n.2, p.70-82, 1997.

SCHUMACHER, M.V. Aspectos da ciclagem de nutrientes e do microclima em talhões de Eucalyptus camaldulensis Dehnh, E. grandis Hill ex Maiden e E. torelliana F. Muell. Piracicaba, SP, 1992, 87p. Dissertação (Mestrado) Escola Superior de Agricultura "Luiz de Queiroz", Universidade de São Paulo. 
SCHUMACHER, M.V.; POGGIANI, F. Produção de biomassa e remoção de nutrientes em povoamentos de Eucalyptus camaldulensis Dehnh, Eucalyptus grandis Hill ex Maiden e Eucalyptus toleriana F. Muell, plantados em Anhembi-SP. Ciências Florestais, v.3, n.1, p.21-34, 1993.

SILVA, H.D. Biomassa e aspectos nutricionais de cinco espécies do gênero Eucalyptus, plantados em solos de baixa fertilidade. Piracicaba, SP, 1983, 91p. Dissertação de mestrado. - Escola Superior de Agricultura "Luiz de Queiroz", Universidade de São Paulo.

SILVA, F.C. Uso agronômico do lodo de esgoto: efeitos em fertilidade do solo e qualidade da cana de açucar. Piracicaba, 1995. 165p. Tese (Doutorado) Escola Superior de Agricultura "Luiz de Queiroz", Universidade de São Paulo.

SILVA, H.D. da; BELLOTE, A. F.J.; FERREIRA, C.A.; REISMAN, C.B.; GAVA, J.L. Modelos para a quantificação de biomassa e nutrientes no tronco de Eucalyptus grandis Hill ex-Maiden. In: "IUFRO Conference on Silviculture and improvement fo Eucalypt". Proceedings. Salvador. Colombo: EMBRAPA. Centro nacional de Pesquisa de Florestas. 1997, p:281-289.

SILVEIRA, R.L.V.A.; HIGASHI, E.N.; GONÇALVES, A.N.; MOREIRA, A. Avaliação do estado nutricional do Eucalyptus: diagnose visual, foliar e suas interpretações. In: GONÇALVES, J.L.M. e BENEDETTI, V. (eds). Nutrição e fertilização florestal, Piracicaba, IPEF, 2000, cap 3, p. 79-104.

TYLER, L.D.; McBRIDE, M.B. Mobility and extractability of cadmium, copper, nickel and Zinc in organic mineral soils columns. Soil Science, v.134, p.198205, 1989.

VAZ, L.S.V. Crescimento inicial, fertilidade do solo e nutrição de um povoamento de Eucalyptus grandis fertilizado com biossólido. Piracicaba, SP, 2000, 41p. Dissertação (Mestrado) - Escola Superior de Agricultura "Luiz de Queiroz", Universidade de São Paulo.

TSADILAS, C.D.; MATSI, T.; BARBAYANNIS, N.; DIOMOYANNIS, D. Influence of sewage sludge application on soilproperties and on tha distribution and availability of heavy metal fractions. Commun. Soil Science.and Plant Analisys, v.26, n.15/16, p.2603-2619, 1995.

TSUTYA, M.T. Alternativas de disposição final de biossólidos gerados em estações de tratamento de esgoto. In: BETTIOL, W. e CAMARGO, O. A. (Eds): Impacto Ambiental do Uso Agrícola do Lodo de Esgoto. Jaguariúna: EMBRAPA Meio Ambiente, 2000, cap. 4, p.69-106. 
U.S. ENVIRONMENTAL PROTECTION AGENCY 1984. 40 CFR Part 503. Environmeental Regulations and Tecnology: Land Application of Municipal Sludge. Fed. Reg. v. 58, n. 32. EPA 625/1-83-016: Cincinnati.

U.S. ENVIRONMENTAL PROTECTION AGENCY. 1999. EPA 530-R-99-009. Biosolids generation, use, and disposal in the United States. Solid Waste and Emergency Response $(5306 \mathrm{~W})$, Office of Solid Waste, Washington. 74p.

VITAL , R. T. Efeito do corte raso no balanço hídrico e na ciclagem de nutrientes em uma microbacia reflorestada com eucalipto. Piracicaba, SP, 1996.,105p. Dissertação (Mestrado) - Escola Superior de Agricultura "Luiz de Queiroz", Universidade de São Paulo.

VLAWIS, J.; WILLIANS, E. Utilization of municipal organic wastes as agricultural fertilizers. California Agricultural, v.25, n.7, p.7-9, 1971.

ZABOWSKI, D.; HENRY, C.L. Soil and foliar nitrogen afeter fertiliser treatment of Pinus ponderosa. New Zealand Journal of Forestry Science, v.24, n.2/3, p.333-343, 1994.

WADT, P.G.S.; NOVAIS, R.F. de. Influência da idade da árvore na interpretação do estado nutricional de Eucalyptus grandis, pelos métodos do nível crítico e do DRIS. In: "IUFRO Conference on Silviculture and improvement fo Eucalypt". Proceedings. Salvador. Colombo: EMBRAPA. Centro nacional de Pesquisa de Florestas. 1997, p.262-268

WEETMAN, G.F.; McDONALD, M.A.; PRESCOTT, C.E.; KIMMINS, J.P. Responses of Western hernlock, Pacific silver fir and Western red cedas plantations ou northen Vancouver Island to applications of sewage sludge and inorganic fertilizer. Canadian Journal of Forestry Researsh, v.23, n.9, p.1815-1820, 1993.

WEN, G.; WINTER, J.P.; VORONEY, P.; BATES, T.E. Potassium availability wit application of sewage sludge, and sludge and manure composts in field experiments. Nutrient Cycling in Agroecossystens, v.47, p.233-241, 1997. 